


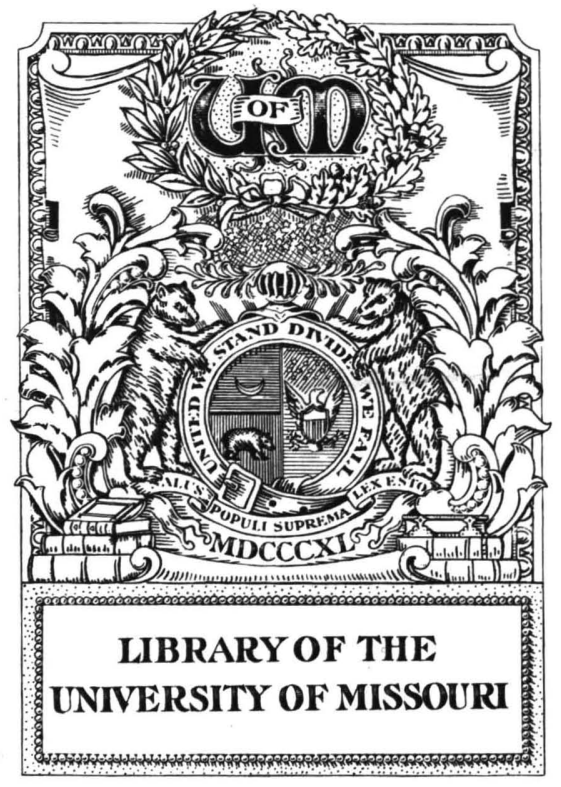






THE FORMS AND EXTENT OF MILTON'S INELUENCE

UPON THOMSON, GRAY: AND COLIIINS

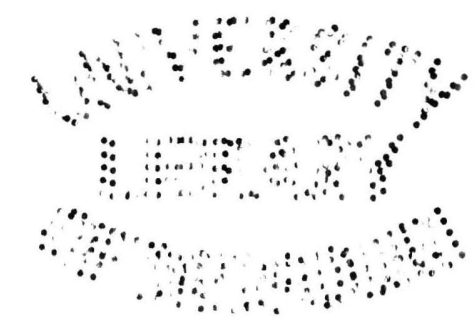

A THESIS SUBMITTED TO THE GRADUATE CONFERENCE OF THE UNIVERSITY OF MISSOURI IN PARTIAL FUIFILIMENT OF THE REQUIREMENTS FOR THE DEGREF OF MASTER OF ARTS.

BY

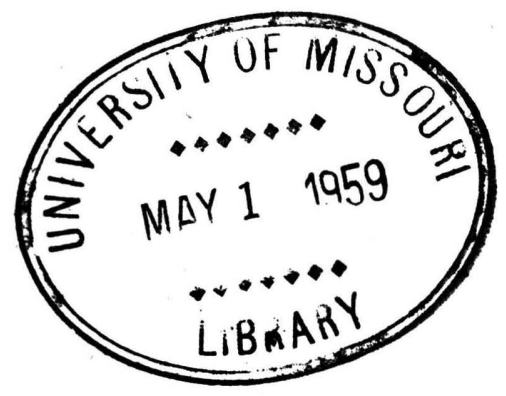

Carolyn Belle Benton, (A. B. 1908)

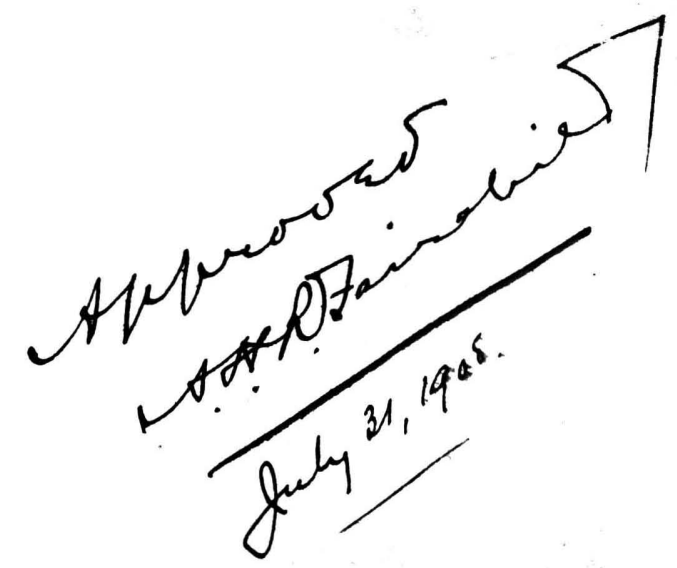




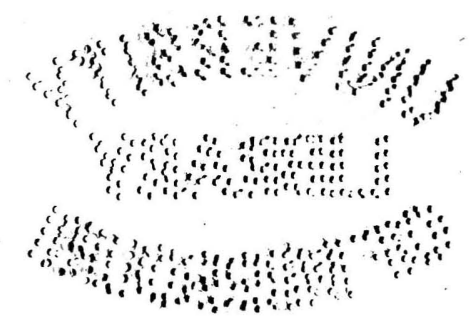


THE FORMS AND EXTENT OF MILTON'S INFLUENCE

UPON THOMSON, GRAY, AND COIIINS

$\begin{array}{lll}\text { Part I. } & \text { The Problem Stated. } & \text { Page } 1 . \\ \text { Part II. } & \text { From Milton to Gray. } & \text { Page } 4 . \\ \text { Part III. Milton's Influence in Verbal Fxpression.Page } 17 . \\ \text { Part.IV. Milton's Influence in Conception. } & \text { Page } 55 . \\ \text { Part V. } & \text { Milton's Influence in Form. } & \text { Page } 89 . \\ \text { Part VI. Minor Influences of Milton. } & \text { Page } 117 . \\ & \text { Conclusions. } & \text { Page } 141 . \\ & \text { Abbreviations. } & \text { Page } 1 . \\ & \text { Bibliography. } & \text { Page V. }\end{array}$





\section{PREFATORY NOTE}

In the following study, the line references to The Poems of Milton are according to The Poetical Works of John Milton, edited by David Masson, London, 1890. References to the poems of Collins and Gray are according to the Athenaeum Press Series, the former edited by Walter $C$. Bronson, the latter by William Lyon Phelps, published by Ginn \& Company, Boston, 1898 and 1902. The references to Thomson's minor poems are according to the British Poet Series, published by Houghton, Mifflin \& Company, Boston. The Clarendon Press Edition (1891) of Thomson's Seasons and The Castle of Indolence, edited by J. Logie Robertson, has been used for the se two poems in preference to the text of the British Poet Series on account of its apparently nearer approach to accuracy. 

THE FORMS AND EXTENT OF MIITON'S INELUENCE

UPON THOMSON, GRAY, AND COILINS

PART I.

THE PROBLEMI ST ATED

When considering the poetry of James Thomson, Thomas Gray, and William Collins, historians of literature, notably Courthope, Gosse, Saintsbury, Crawshaw, Ward, Warton, and others, have been content to say that Milton had a marked influence upon the poetry of the se eighteenth century Romanticists. Professor Beers has devoted one chapter of his History of English Romanticism in the Eighteenth Century to The Miltonic Group. After quoting at some length from Akenside, Mason, and the Wartons to prove their verbal indebtedness to Milton, he says, "In Gray and Collins, though one can hardly read a page without being reminded of Milton, it is commondy in subtler ways than this. Gray, for example, has been careful to point out in his notes his verbal obligations to Milton, as well as to Shakespeare, Cowley, Dryden, Pindar, Virgil, Dante, and others; but what he could not well point out, because it was probably unconchious, was the impulse which Milton frequently gave to the whole exercise of his imagination." (1). Professor Phelps has also devoted one chapter in 1. A History of English Romanticism in the Eighteenth Century. 

his The Beginnings of the English Romantic Movement to Milton's influence. He states that the Romanticists followed Milton in thought, language, and versification, and that Milton's influence cannot be traced out in any very definite way, but must be followed along general lines. In speaking of Collins he states that his love for Milton comes out in "occasional phrases" and quotes only one, while Gray's indebtedness is dismissed with the statement that his Elegy with its "pensive mood and love of twilight" is in the II Penseroso vein. (I). Professor Raleigh has pointed out three or four instances of the verbal indebtedness of Thomson and Gray to Milton. (2). Robertson, in the notes to his edition of The Seasons and The Castle of Indolence, and the editor of Gray in the British Poet Series, as well as other editors in their notes and introductions, have indicated some few passages in the poems of Thomson, Gray, and Collins that are paralleled in Milton. The influence of Milton upon the form of Collins and Gray has been neglected. In regard to Thomson's form, Samuel Johnson says, "Thomson's mode of thinking, and of expressing his thoughts is original. (3) His blank verse is no more the blank verse of Milton, or of any other poet, than the rhymes of Pryor are the rhymes of Cowley. His numbers, his pauses, his diction, are of his own growth, without transcrip-

1. The Beginnings of the English Romantic Movement, $87-88,96$. 3. The italics are mine. 

tion, without imitation."(1) A more recent editor, Robertson, echoes this statement when he remarks, "The blank verse of The Seasons is Thomson's owk. It is distinct from Milton's."(2) Leon Morel in his book, James Thomson: Sa vie et ses oeuvres, very directly and explicitly acknowledges the indebtedness of Thomson to Milton both in form and conception. He tells us that Milton is Thomson's "master and model", that his influence appears everywhere in The Seasons, and that his blank verse was inspired by Milton. (3) But he merely makes the statement; he offers no evidence in confirmation or support of it.

The attempt to trace in some detail and to indicate to some extent the influence of Milton upon the conceptions and language of Thomson, Gray, and Collins; to show that their obligation to him is something more specific than can be indicated along "general lines"; to point out the indebtedness of Collins and Gray to Milton's versification, and to posit some evidence in the matter of Thomson's debt to Milton in form, is the province of this paper.

1. Iife of Thomson in Introduction to The Seasons, XVII.

2. GeneraI Introduction to The Seasons, 28.

3. "Milton, $\forall 0 i l$ araiement le maitre " et le modèle de Ihomson". (407) C'est au grave et majesteaux auteur du" Baradis Berdu qu'il demande le secret d'une versificatpion fiere, pompeuse, digne de ce sujet". (408) "son mâ̂tre, le grand Milton". (410) "Milton, le mâtre dont l'influence profonde apparût partout dans les saisons". (424) I'auteur des Saisons, diciple fervent de Milton". (634) Cf. also pages $437,198,129,456,460$,etc. 

PART II.

\section{FROM MIITON TO GRAY}

Action and reaction are phenomena that exist in the mental, moral, spiritual, and aesthetical worlds as well as in the physical world. In every phase of life we can trace this ebb and flow whether it be in intelectual conceptions, soclological principles, religious ideas, artistic ideals, or in the law of expansion and contraction. Matthew Arnold has pointed out how "Hebraism and Hellenism", as he has named certain forces, have alternately dominated our mental and moral spheres. (1) They are, indeed, two mighty fundament al conceptions that have always been, and probably always will be, potent factors in determining the course of human events and human reasoning. The struggle between "spontaneity of consciousness" and "strictness of conscience" is an old and ever renewed combat. Spirituality of mind, that Puritan characteristic, which leads its possessor to believe in the invisible world and to refer to it, both in his thoughts and actions, (2) must of ten meet in battle that Hellenistic charactistic that refers to the visible world for its guidance in all forms of human activity. In such a struggle there is no complete victory possible; because, as Professor Caird says, "there 1s no possible victory of idea over idea except by their common absorption in one which is higher and more comprehensive than

1. Hebraism and Hellenism.

2. Cf. Shedd: Iiterary Es says, 238. 

either. Here, indeed, the contrast is so deep and far-reaching that the opposite forms of thought are continually finding new forms of expression for themselves and the conflict that seemed to be ended in one generation breaks out again in the next." (1)

In the sixteenth century Hellenism in literature was manifested in the works of the poets of the Elizabethan period. Reason, passion, and imagination co-operated to give substance and form to the poetry of Shakespeare and of Spenser, to the prose of Bacon and of Hooker. The literature of pleasure had never before combined such beauty with such seriousness, and the literature of knowledge had never contained such imaginative strength. But gradually the Hellenistic ideals in literature suffered degradation. The ideals of poetry became involved with political ideals, and in the solution of practical, urgent problems, much of the nobility of poetical ideals waned. A period of political passion, of perplexed reason, and of easy and vulgar imagination ensued.

The reaction came with Puritanism. Hebraistic conceptions gained the mastery in the seventeenth century, and were not without their influence upon poetry. The moral conceptions of the Puritans did not encourage literature and did not lead to a generous development of art. The charactistics of Puritan-

1. The Evolution of Religion, II, 25.

2. Cf. Dowden: Puritan and Anglican: Studies in Iiterature, 

ism,- "compulsory piety, with hypocrisy in its train, sanguinary laws against heresy and blasphemy, execution of popish priests, burning of witches, suppression of natural pleasures and of the harmless gaiety of life, inward vice," (I)- all this was not conducive to the best that art is capable of attaining. As a consequence, under Buritanical dominion, poetry in England deteriorated.

With the re-entrance of Hebraism appeared John Milton, who has been called the complete representative of Puritanism. He was born eight years before the death of Shake speare, and died fourteen years after the Restoration. He lived only a few years after the reign of Elizabeth, and he saw the beginning, the triumph, and the fall of the Commonwealth. Thus, he belongs at once to the Renaissance and to Puritanism. And what a contrast this presents! "On one side every curiosity of intelligence, every research of language, every refinement of taste; poetry, with its mythology, its sports, its license; the cultus of pagan antiquity; a false wisdom and false gods; madrigals, novels, the theatre. On the other, ardent fanatics, sombre anchorites, fanatic levellers, full of hatred for Sat an and his pomps, caring for nothing but long sermons and excited prayers, broken in to the dogmas of Predestination, of the Fall and Justification, burning to make of Englishmen a new people of Israel." (2) Much of Milton's genius as a 

poet is explained by this kinship: He was not a poet of the great creative age, but of that age's morrow, a morrow still possessed of spontaneity and conviction. Yet in his later poems, we find Milton didactical and religious,- a necessary result of his living in the seventeenth century. There is evidence that Milton in his early life seriously questioned whether his lot should be cast with Hebraism or Hellenism. In Iycidas, which may be said to conclude the poems of his earlier period, we find him asking whether he shall "scorn delights and live laborious days," or "sport with Amaryllis in the shade". He asks this question; but he triumphantly negates it. In his large nature there was a certain reconcilement of the conflicting claims; but even the genius of Milton found it impossible permanently to maintain the double allegiance, and his later poems show unmistakable and unquestionable proofs of his Puritanical severity. Under Cromwell, Puritanism flourished, and Wither, Bunyan, Milton were the natural products of their time.

With the Restoration came the beginning of new life in thought and in literature. The theatres were re-opened for dramas that were light and immoral. The May-Boles were set up again, the Puritan Sabbath was disregarded. The reaction against Puritanism tended toward frivolity, licentiousness, and practical, if not theoretical irreligion. The Age of Dryden was followed by the Age of Pope, and by a happier mean. 

Pope's England was not a religious England; it did not experience any great revival of morality or of religious zeal; but it did perceive that the previous generation had gone too far, that its spirit was destructive of society and of the highest values in literature, and that effort must be made to bring back a purer moral tone. This effort was consciously and effectively made, and the literature of the age became vastly cleaner, both in language and thought. There was no reversion to Puritanism; the men of the time had little taste for that. But there was a reaction against moral lawlessness; and the age took a middle ground between Puritan strictness and Restoration licentiousness. (1) In the literature of this period, as Leslie Stephen has pointed out, we find reflected "the national character, its common sense; the intellectual shortsightedness which enables it to grasp detalls whilst rejecting general systems; the resulting tendency to compromise, which leads it to acquiesce in heterogeneous masses of opinion; its humour, its deep moral feeling, ițs prejudices, its strong animal tendencies." (2)

For guidance and inspiration, England turned to France. At this time the French litterateurs were attempting to write with exactness, elegance, and with great care for the correctness of the language in which the thought was expressed. This

1. Cf. Crawshaw; The Making of English Literature, 196.ff. 2. History of English Thought in the Eighteenth Century, 330. 

doctrine met with special favor in England because it exactly suited the general tendency of the times. The Popian circle instinctively acknowledged the truth that all spiritual, political, and artistic development must proceed in conformity with law. Correctness in metrical composition to Pope implied obedience to the laws of imaginative thought; and, therefore, involved not only precision of metrical expression, but justness of poetical conception. In this sense, the writings of the seventeenth century were astonishingly incorrect. The poets of the age sought to invest with fanciful and romantic forms, thoughts and feelings which had long since ceased to move the imagination of society. Pope perceived this, and he understood "that the quibbles, refinements, and affectations that mark their style, were the products of imaginative exhaustion." (I) So the school of Donne and Cowley fell into disfavor; the conceits, the vagaries, the tawdry ornaments of style were discarded. Clearness, propriety, mode ration we re cultivated.

As a consequence, Pope and his school went to the other extreme. They left a literature characterized by self-restraint and objectivity, with no flights of the imagination, and with a narrow and imperfect sense of duty. It was a literature of high life, fashion, society. The general, the abstract, the typical were exalted. There was an at tempt to

1. Courthope: The Iiberal Movement in English Iiter ature, 59-60 

make poetry fit into certain rules and codices. "The poet was never to throw the reins upon the neck of his passion, or to abandon himself to a fine frenzy in defiance of mechanical laws." (1) Imagination and pasion were restrained, in order that mere expression might be polished and refined to the last degree. The poetry of Pope's age was not the poetry that comes from general feeling and emotion, but the poetry that comes from the formal statement of intellectual conceptions.

For their models in the literary world, this age took the ancients. Fidelity to the original model was more excellent than any amount of originality or spontaneity. The old English writers were regarded with contempt and indifference. Chaucer was not thought worthy of serious treatment; Spenser fared no better; Shakespeare was not widely read, and many of those who read his dramas did not understand them; Milton was almost unknown. His poems were neither studied nor read. The old English style in poetry and romance was generally spoken of as "Gothic"; a term of reproach, used to designate a style which they did not wish to imitate and which they considered barbarous. Even Shake speare was half-Gothic. The criticisms of Theobald, Warburton, Pope appeal to us as irreverent and absurd. One bright intellect put Hamlet's soliloquy into the heroic couplet. Atterbury thought that if Pope

\section{Stephen: Op. Cit., II, 354 .}



would polish and improve Milton's Samson Agonistes it might be made into a model and standard of tragic poetry. (I)

In form, it was a mooted point whether tragedy should be in rhyme, after the French manner, or in blank verse, after the precedent of the English stage. But it was considered bad form to write poetry other than dramatic in blank verse. Johnson regarded it as little short of immoral. Pope has left no blank verse. Even the heroic couplet as written by earlier poets was felt to have been too loose in structure. Pope is praised by Johnson because he employed but sparingly the triplets and Alexandrians by which Dryden sought to vary the monotony of the couplet. In fact, the heroic couplet, which Pope brought to perfection and to which he gave all the energy and variety of which it was capable, thoroughly prevailed for a century or more.

This artificiality could not last. Again, the reaction came. The political corruption, the coldly intellectual temper, the studied repression and cynicism of the day had to gi ve way before the fervor of a rising spirituality. Just as the mood of dissolute levity which immediately succeeded the Restoration passed into an era of comparative good-sense, so the little vanities and complaisant optimism of pope, the moroseness, contempt, and scorn of Swift, the superficialities of this age had to submit to the higher side of men's natures

1. For authority, Cf., Phelps: Op. Cit., $15 \mathrm{ff}$. 

which again began to assert itself.

The middle of the eighteenth century witnessed the predominance of a finer feeling. On the religious side, the reaction was seen in the enthusiasm with which Methodism was received. The cold intellectual speculations of Bolingbroke and the skepticism of Hume were interrupted by the pasionate outbursts of Whitfield and Wesley. Ethically, a feeling of compasion and pity seems to have stirred humanity. A united move was begun against slavery; the conditions of the prisons were improved; criminals on the way to execution were no longer dragged through the streets for a public show. It was at this time that Handel came into popularity. Audiences, only a short time before delighted with immoral wit and low forms of amusement, rose with one accord and stood through the singing of parts of Handel's Messiah.

Politically, there was a great appeal to patriotism under the animating spirit of William Pitt. "He restored the finances and reformed the financial system. He converted deficit into surplus. By his commercial treaty with France he made a great advance toward the realization of Adam Smith's policy of free trade. The country was prospering and growing rapidly in wealth. The inventions of Arkwright, Hargreaves, Crompton, Watt, and Wedgewood, together with the invention of smelting Iron with coal, gave an immense impetus to manufactures of 

all kinds, to metallurgy and to mining". (1) Trade with Canada and with India added the undeveloped resources of the West and the products of the whole rich civilization of the East to the hitherto insular commerce of England. Democracy, with all its ideas in regard to human equality and brotherhood and the rights of man, steadily made itself felt as a mighty power.

The political and social changes were reflected in poetry. The new sympathy for suffering and the new spirit of democracy wer manifested in lite rature. The imagination and the passion of the Elizabethan age returned in no small degree. The departure of the poets from the $i$ deals of the classical school showed itself in a delight in the world of mediaeval chivalry, and in the hitherto neglected ballads of the people. A perception of natural beauty, a new refinement, a changed intellectual activity characterized this period in contrast to that of the Augustan age. The romantic, the naturalistic, the emotional, the democratic, and the religious movements were intermingled and blended in the literature of the age.

In form there was a change. Pope and $h$ is school had given a perfect polish to the couplet, "had revived a public interest in sat ire and philosophic speculation in verse, had canonized and rendered the technique of heroic verse a thing which could be studied like a language or a science. It was strictly in accordance with the traditions of literature that no sooner was the thing easy to do than the best poets lost interest in doing

1. Smith, Goldwin- Op. Cit., II, 255. 

it." (1) Fuactness of form gave way to beauty of form. Yet the change in this line of activity, as elsewhere, was not a violent one. Reform is rarely universal. Many of the featur es which had characterized the Restoration literature were prolonged until late in the eighteenth century, and some poets modelled their style on Pope and Addison until the century's close. Young, Blair, Henry Brooke, Erasmus Darwin echo the heroic couplet of Pope. Even the efforts of those who were dissatisfied and who desired something better found their point of departure, not in creative work, but in the loving study and revival of old authors. Pryor, Croxall, Shenstone, Thomson, in his Castle of Indolence, Cambridge, William Thompson, William Wilkie, Gilbert West, Mickle, and others turned to a diligent study and revival of Spenser, imittating him in form and in language, and writing essays and observations on his art as exhibited in the Faery queene.

The poet scarcely second to spenser in this revival, the man who was the head of the movement known as Romanticism, the man whose poems furnished the standard and the model for the best that the eighteenth century produced was John Milton. It has been pointed out that his poems give evidence of classical, or Hellenistic tendencies and of Puritanical, or Hebraistic. To the men of the eighteenth century his'message was one of Romanticism; they acceted him on the Hellenistic side. Whereas he had been shunned, avoided, and neglected

1. Gosse: Modern English Literature, 233. 

by the Popian circle, he was now fondly cherished, admired, and loved. By 1713, Tonson brought out an edition of Milton which was the ninth of Paradise Iost, the eighth of Paradise Regained, the seventh of Samson Agonistes, and the sixth of the minor poems. The first edition of the minor poems was in 1645. Six editions in sixty-eight years certainly does not bespeak a wide-spread popularity. After 1713 editions multiplied rapidly; by 1763, Paradise Lost was in its fortysixth edition, and the minor poems in their thirtieth. Milton's influence in poetry upon his own age seems to have amounted to almost nothing; he was practically unknown to his Iondon contemporaries. His style and his work were his own and he had neither school nor followers. No one imitated or was influenced by his lyric poetry, and, until the eighteenth century was well advanced, it was scarcely read. (1)

Addison, perchance, was the initiator of the Miltonic revival. Beginning with December 31, 1711, he published in the Spectator a series of critical papers on Milton. This was followed, as we have stated, by many editions of Milton's works. Joseph Warton, writing in 1756, after quoting copiously from the Nativity Ode, which, he says, "is not sufficiently read nor admired",continues: "I have dealt chiefly on this Ode as much less celebrated than I'Allegro and II Penseroso, which are now universally known; but which, by a strange fatality lay in a sort of obscurity, the private enjoyment of a few 1. Cf. Gosse: Op. Cit., 145, 168. Raleigh: Op. Cit., 229. 

curious readers, till they were set to admirable music by $\mathrm{Mr}$. Handel. And indeed, this volume of Milton's miscellaneous poems has not till very lately met with suitable regard. Shall I offend any rational admirer of Pope, by remarking that the se juvenile descriptive poems of Milton, as well as his Latin elegiacs, are of a strain $f$ ar more exalted than any of the former author can boast?" (I)

The first critical edition of the minor poems was published in 1785 by Thomas Warton. As late as 1779, Johnson spoke of the se same poems with an absence of appreciation that seems astounding. James Thomson (1700-1748) was the first man to make a real study of Milton and it is he who is the "real pioneer of the whole Romantic movement with its return to nature and simplicity". (2) Milton's influence became more decidedly noticeable, however, in the work of a group of lyrical poets, Collins, Gray, Mason, and Joseph and Thomas Warton. To show how Milton influenced the greatest poets of this group, Collins and Gray, and his influence upon the Romantic pioneer, Thomson, will occupy the remainder of this paper.

1. Essay on Pape: I, 36-38. Quoted, Beers: Op. Cit., 149ff. 2. Gosse: Op. Cit., 230 . 



\section{PART III.}

\section{MILTON'S INFLUENCE IN VERBAL EXPRESSION}

Perhaps the clearest proof of the influence of Milton upon the poets of the eighteenth century is to be found in the number of phrases they have adopted from him and have incorporated in their own poems. In many cases, the exact words of Milton are found. Thomson, Gray, and Collins seem to have been so familiar with Milton's lyrics that the language of Il Penseroso and I'Allegro apars from time to time in their writIngs as if it were their own. Gray, indeed, has pointed out three instances of his indebtedness to Milton's poems. That there are many more, the following study demonstrates. No poem of Milton's influenced the Romanticists more than Il Penseroso. Its verbal influence upon Thomson, Gray, and Collins becomes apparent upon an examination of the succeeding pages. 

VERBAL P AR AILIEISS

A.

The brood of Folly without father bred!

II $\underline{P} \cdot 2$.

Self-pleasing Folly's idle brood,

(

O'erlaid with black, staid Wisdom's hue;

II $\underline{\mathrm{P}}$. 16 .

Wisdom in sable garb array'd,

(4) Advers. 25

Thee bright-haired Vesta long of yore

II $\underline{P} \cdot 23$

o nymph reserv'd, while now the brighthair'd sun $\frac{\text { Even } .5 .}{(C)}$

Sober, steadfast, and demure,

II $\underline{P} \cdot 32$,

Those looks demure, that deeply pierce the soul,

(-) Spring, 485 .

Over thy decent shoulders drawn,

But com'st a decent maid
II $\underline{P} \cdot 36$

(1) Simplic. 10 .

With a sad leaden downward cast $\quad$ II P. 43.

Desponding Meekness with her downcast eyes;

(c) Or. Ec. 65 .

Come with those downcast eyes,

(1) Spring, 484

With leaden eye, that loves the ground, (1.)

Advers. 28.

C.

1. Sidney, has "leaden eyes", Astrophel and Stella, Song 7. 

And oft, as if her head she bowed,

Stooping through a fleecy cloud.

II P. $71-72$.

Now through the passing cloud she seems to stoop,

(T) Aut. 1096

or the tale of Troy divine,

Ennobled hat the buskined stage.

II 怾. 100-102.

The buskin'd Muse shall near her stand,

With each disastrous tale. + (c) Pity, 34-36.

'In buskin'd measures move $\quad(g)$ Bard, 128.

of turneys, and of trophies hung,

II ․․ 118 .

At solemn turney hung on high,

(c) Poet. Char. 7.

To arched walks of twilight groves,

"Ye brown o'er-arching Groves,

II P. 133.

(4) Music, 27 .

And shadows brown, that Sylvan loves,

II P. 134 .

Where'er the oak's thick branches stretch

A broader, browner shade;

(9) Sp. Ode, 11-12.

While the bee with honezed thigh,

II $\underline{P} \cdot 142$.

- - where the bee

of fragrant woodbine loads his little thigh.

(1) Sum. 626-628, 

To walk the studious cloister's pale,

Casting a dim religious light.

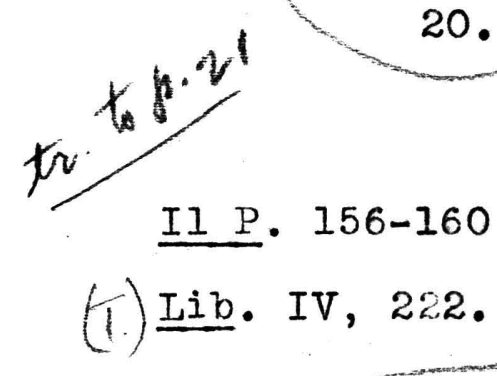

- - cloisters dim

(1.) Iib. IV, 222 .

With antique pillars massy-proof,

II $\underline{\text { P. }} 158$.

Ye distant spires, ye antique towers, $\left(\frac{1}{y}\right)$ Eton Col. 1 .

And storied windows richly dight

Can storied urn or animated bust

II … 159 .

(i) Elegy, 41 .

There let the pealing organ blow,

In service high and anthems clear,

II P. 161-163.

The pealing anthem swells the note

(b)Elegy, 40 .

The hairy gown and mossy cell,

II ․․ 169 .

- - sought of peace the mossy celI, (T) Cast. Ind. II.679.

The se pleasures, Melancholy, give;

And I with thee will choose to live. II. P. 175-176.

His cypress wreath my meed decree,

And I, 0 Fear, will dwell with thee! (1)/ Fear, 70-71.

1. Possible common source

"If these delights thy mind may move,

Then live with me and be my love."

Marlowe: The Passionate Shepherd to His Love. 



\section{1.}

It is probable that Milton's influence suggested these passages, although the verbal parallels are less obvious.

\section{B}

Hail, divinest Melancholy!

And Melancholy, silent maid

II $\underline{P} \cdot 12$.

(g) Advers. 27.

Guiding the flery-wheelèd throne,

II $\underline{P} .53$.

The living Throne, the saphire blaze, (9) Prog. Poes. 99.

Sometime let gorgeous Tragedy

II $\underline{P} \cdot 97$.

- - - Seneca be there

In gorgeous phrase of laboured eloquence.

(4) Agrip. 148-149.

While the bee with honeyed thigh,

II P. 142 .

The insect youth are on the wing,

Eager to taste the honied spring,

(4) Sp. Ode, $25-26$.

Entice the dewy-feathered Sleep.

II $\underline{P} \cdot 146$.

Shook thousand odours from his dewy wings.

(C) Passions, 94.

To walk the studious cloister's pale,

II $\underline{P} \cdot 156$.

In cloisters dim, far from the haunts of Foliy,

With antique pillars massy-proof,

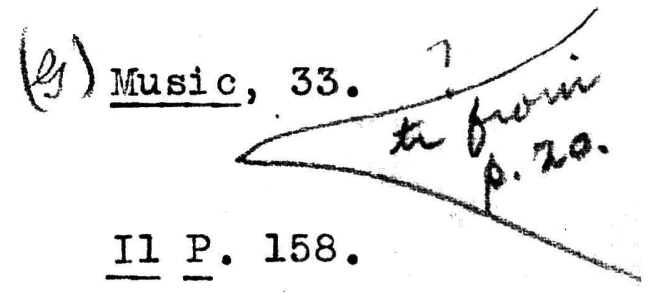

-. - - - secure in massy hall.

(T) Cast. Ind. I,387. 

And storied windows richly dight,

Casting a dim religious light.

II P. $159-160$.

Rich windows that exclude the light, l Iong Story, 7.

[From here tum to p. 2].]

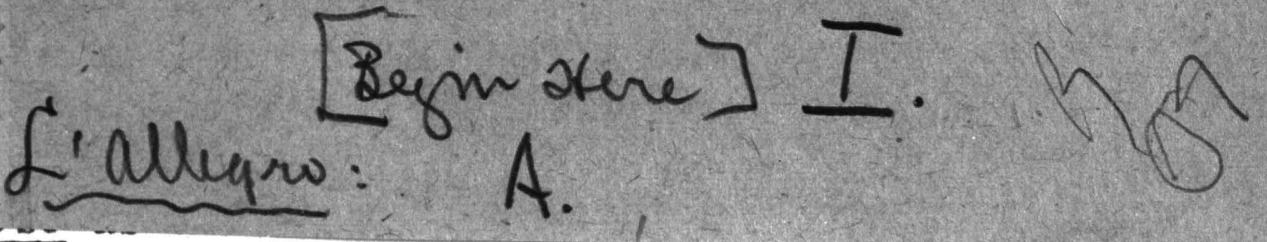

Where brooding Darkness spreads his jealous wings,

There, under ebon shades and low-browed rocks,

I'A. 6-8.

Where, tangled round the jealous steep,

Strange shades o'er-brow the valleys deep,

(C) Poet. Char. 57-58.

The frolic wind that breathes the spring, I'A. 18.

To breathe a second sp ring.

(b) Eton Col. 20 .

Mirth, admit me of thy crew,

I'A. 38.

Me too amidst thy band admit,

(c) Mann. 53.

In unreproved pleasures free $;$

I'A. 40.

With laughter unreproved.

(1) $M r$. Congreve 52 ,

Till the dappled dawn doth rise;

I'A. 44 .

At first faint-gleaming in the dappled ast;

() sum. 48 . 
And storied windows richly dight,

Casting a dim religious light.

II ‥ $159-160$.

Rich windows that exclude the light, I Long Story, 7.

The Influence of L'Allegro upon Thomson, Gray, and Collins is scarcely second to that of II Penseroso. The debt to I'Allegro in ve rbal influence is larger than that to II Pense-roso as the citations indicate:

Where brooding Darkness spreads his jealous wings,

There, under ebon shades and low-browed rocks,

I'A. 6-8.

Where, tangled round the jealous steep,

Strange shades o'er-brow the valleys deep,

(C) Poet. Char. 57-58.

The frolic wind that breathes the spring,

To breathe a second sp ring.
I'A. 18.
(y) Eton Col. 20 .

Mirth, admit me of thiy orew,

I'A. 38.

Me too amidst thy band admit,

(c) Mann. 53 .

In unreproved pleasures free;

I'A. 40.

With laughter unreproved.

(1) $M r$. Congreve 52 ,

Till the dappled dawn doth rise;

I'A. 44 .

At first faint-gleaming in the dappled Last;

(1) sum. 48 . 
Right against the eastern gate

Right against the eastern gate,
I'A. 59.

(乌) Des. Odin, 17 .

Russet lawns, and fallows grey, I'A. $7 I$. Oft let me wander o'er the russet 电ad ) Aut. 971. Or upland fallows grey (c) Even. 31.

Mountains on whose barren breast I'A. 73. Whose barren bosom starves her Eengrous birth,

(4) Educ. and Gov. 2.

Towers and battlements it sees I'A. 77.

Ye distant spires, ye antique towers, (1)

(9) Eton Col. 1.

Bosomed high in tufted trees, I'A. 78. And villages embosomd soft in trees, Spring, 952.

The upland hamlets will invite, I'A. 92 . C To meet the sun upon the upland lawn. $(4)$ Elegy, 100.

And the jocund rebecks sound L'A. 94. While airy minstrels warble jocund notes.

1. Other evidence makes it practically certain that Gray has this passage in mind. 

To earn his cream-bowl duly set, I'A. 106.

To the swart tribes, their creamy bowl allots;

c) Pop. Super. 23 .

Where throngs of knights and barons bold, I'A. 119. Girt with many a Baron bold

(1) Bard, 111 .

With mask and antique pageantry; I'A. 128. In pageant quaint, in motley mask, + C) Mann. 40.

On summer eves by haunted stream. $\underline{L^{\prime} A} \cdot 130$. of haunted stream ${ }^{-}-$ (1) Sum. $11-12$

Or sweetest Shakespeare, Fancy's child, I'A. 133. There Shakespeare's self, -... fancy sheen, (I) (C) Pop. Super. $176-17 \%$.

Warble his native wood-notes wild. L!A. 134.

Wild warbling nature all, above the $r e$ ach of art,

(1) Cast. Ind. I, 369

While airy minstrels warble jocund notes. (C) Pop. Super. 25 .

And ever, against eating cares, I'A. 135. Of cares that eat away thy heart with Eat up with carking care - Cast. Ind. I, 93. 1 cast. Ind. I, 445 . 1) Anowed.

(7. Horace has "eating cares", II, XI, 18.) omit 

Lap me in soft Lydian airs,

Ne'er let me change this Lydian me asure,

Such as the meeting soul may pierce,

Thou, only thou, canst raise the meeting soul!
I.'A. 136 .

(c) Iib. Ode, 47 .

I'A. 138.

(6) Simplic. 48 .
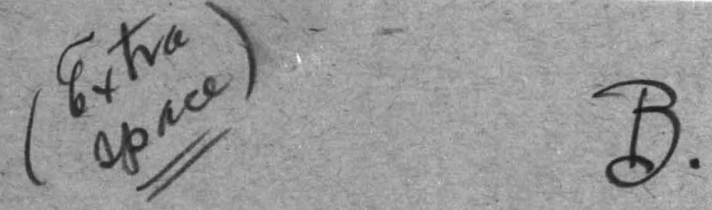

The frolic wind that breathes the spring, I'A. 18. Frisking light in frolic measures; (9) Prog. Poes. 31.

Quips and Cranks, and wanton Wiles, I'A. 27.

When wanton gales along the valleys play, (I)

(C) or. Ec. I, I, 15

And Lamghter holding both his sides. L'A. 32.

Calls Laughter forth deep-shaking every nerve.

Win: 616

On the light fantastic toe;

I'A. 34 .

Love fram'd with Mirth a gay fantastic round;

(c)passions, 90

The mountain-nymph, sweet Liberty; I'A. 36 .

Hail nymph, ador'd by Britain, hail! + (C) Iib. Ode, 63.

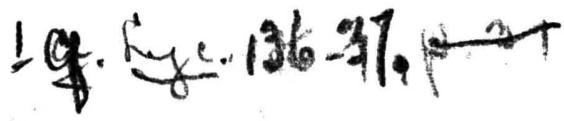


Lap me in soft Lydjan airs,

Ne'er let me change this Iydian me asure,
I'A. 136 .

(c) Iib. Ode, 47 .

I'A. 138 .

Such as the meeting soul may pierce,

Thou, only thou, canst raise the meeting soul!
(4) Simplic. 48

Although the parallels are less immediate, Milton's influence was probably operative in the passages that follow:

The frolic wind that breathes the spring, I'A. 18. Frisking light in frolic measures; $(0)$ Prog. Poes. 31.

Quips and Cranks, and wanton Wiles, I'A. 27. When wanton gales along the valleys
play, (I)

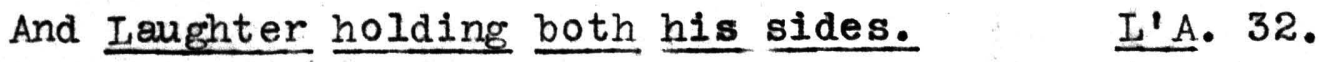
Calls Laughter forth deep-shaking every nerve.

(1) Win: 616

On the light fantastic toe;

I'A. 34 .

Love fram'd with Mirth a gay fantastic round;

(c) passions, 90

The mountain-nymph, sweet Liberty; I'A. 36 .

Hail nymph, ador'd by Britain, hail! +(C)Iib. Ode, 63.

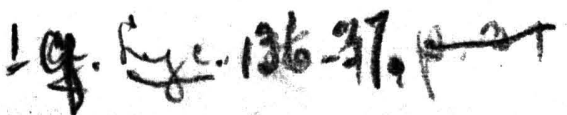



To hear the lark begin his flight, And, singing, startle the dull night,

\section{I'A. $7 / 4+4 \%$}

- - - - -Up sp rings the lark,

Shrill-voiced and loud, the messenger of morn:

By whispering winds soon lulled asleep. I'A. 116.

While whisp'ring pleasure as they fly,

Cool zephyrs thro' the clear blue sky $\left./ /{ }^{\prime}\right)$ sp. Ode, 8-9.

If Jonson's learned sock be on, I'A. 132 .

The comic sock that binds thy feet! (C) Mann. 50.

Or sweetest Shakespeare, Fancy's chi.ld, Warble his native wood-notes wild.

In loose numbers wildly sweet I, A. 133-134.

Is not wild Shake speare thine and Nature's boast?

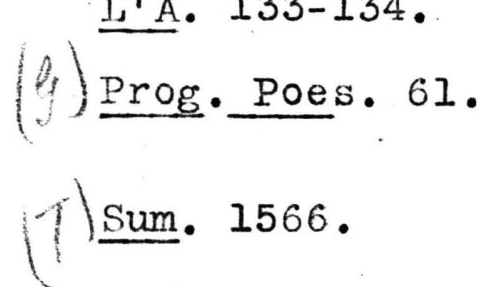

\section{Inose to stemogrepter: Juru tó. p. 18 .}

have been completely or partially paralleled by the se Romanticists.

The supposition of general indebtedness thus indicated is further enforced by a consideration of the influence of 
To he ar the lark begin his flight, And, singing, startle the dull night,

- - - - Up sp rings the lark,

Shrill-voiced and loud, the messenger of morn;

By whispering winds soon lulled asleep. I'A. 116.

While whisp'ring pleasure as they fly,

Cool zephyrs thro' the clear blue sky (1) Sp. Ode, 8-9.

If Jonson's learned sock be on, L'A. 132.

The comic sock that binds thy feet! C Mann. 50.

Or sweetest Shakespeare, Fancy's child, Warble his native wood-notes wild.

In loose numbers wildly sweet

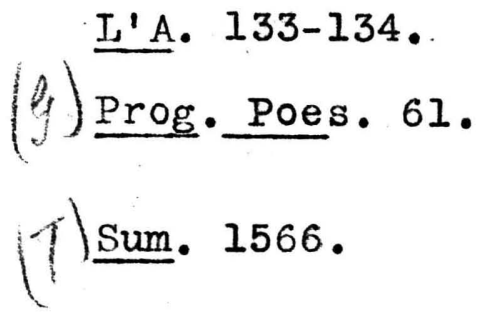

Is not wild Shake speare thine and Nature's boast?

Sum. 1566.

In II Penseroso and I'Allegro, with a total of three hundred twenty-eight lines, there are sixty-three instances In which Thomson, Gray, and Collins have borrowed verbal expressions. Some of the lines from milton have been imitated more than once, but, allowing for such cases, fifty-four lines, or thirteen per cent of the lines of II Penseroso and I'Allegro have been completely or partially paralleled by the se Romanticists.

The supposition of general indebtedness thus indicated is further enforced by a consideration of the influence of 

Milton's other minor poems upon Thomson, Gray, and Collins.

Or that crowned Matron, sage white-robed Truth?

With these the white-rob'd maids combine

(I)

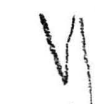

Death of Inf. 54 .

(c) Mann. 45 .

New shot up from vernal shower;

March. Win. 40.

- - - -with vernal showers distent. (7) Spring, 145.

Call on the lazy leaden-stepping Hours,

Time, 2.

The dreadful hour with leaden pace approach'd,

(I) Lizy's Cat, 1 .

The flowery May, who from her green lap throws

May Morn. 3.

In thy green lap was Nature's Darling laid,

Prog. Poes. 84

With joy and gladsome cheer,

Ps. IXXXIV, 7.

And lively chear, of vigour born; (2) $\left(l_{1}\right)$ Eton Col. 47 .

His starry front low-roofed beneath the skies:

Passion, 18.

sublime their starry fronts they rear (f) Bard, 112.

1. Reference to Truth.

12. Spenser has, "In either cheeke depeyncten lively cheere." Hobbinol's Dittie, 33 . 

Over the pole thy thickest mantle throw, Passion, 29-30. Night - ... - -

In mantle dun,

$$
\text { (T) Sum. 1685-87. }
$$

And ye, the breathing roses of the wood, Arc. 32. scent the new fragrance of the breathing rose, 9) Educ. and Gov. 56 .

O'er the smooth enamelled green, Where no print of step hath been, Arc. $84-85$. - - round thy green retreat, On whose enamelid side

Through the soft silence of the listening

$$
\text { night } \text { Circum. } 5 .
$$

Through the soft silence of the listening night

And sing their wild notes to the listening waste.

Pspring, 25

Of sad Electra's poet had the power Son. VIII, 13.

Sooth'd sweetly sad Electra's poet's ear:

Simplic. 18.

With praise enough for Envy to look wan; Son. XIII, 6 . And Envy wan, and faded care, (I) (ly) Eton Col. 68.

1. Cf. (also) P. I. I, 601-602. "and care sat on his faded cheek," 

And Worcester's laureate wreath: ، . $\quad$ Son. XVI, 9. Whe laureate wreath, that Cecil wore, $(9)$ Music, 84.

Help waste a sullen day, . . Yesterday the sullen year

Down through the turning sphere,

But thou who hear'st the turning + spheres,
Son. $X X, 4$

(y) Viciss. 21 .

Nat. Ode, 48 .

(C) Peace, 10.

And bid the weltering waves their oozy channel keep.

Nat. Ode, 124 .

The joy that shall their oozy channels swe 11 .

Past. Dav. Th: 26

With hollow shriek the steep of Delphos

le aving.

Nat. Ode, 178.

Woods, that wave o'er Delphi's steep,$(f)$ Prog. Poes. 66.

Ye myrtles brown, with ivy never sere, $\quad$ Lyc. 2.

- - - - - she sees her myrtles bloom,

Green and unwither'd - - - + (C) Thos. Hanmer, 3-4.

Himse If to sing, and build the lofty rhyme. Lyc. Il.

Build to him the lofty verse,

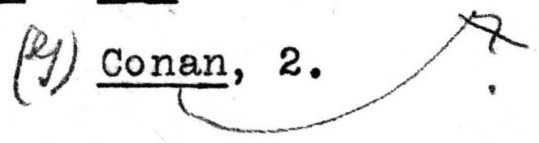

Begin, and somewhat loudly sweep the string. Iyc. I7.

- - - thou yet shall sweep the lyre; (1) Cast. Ind, I, 284. And swept with hurried hand the strings.

(C) Passions, 24. 

For we were nursed upon the self-same hill, Iyc. 23.

In social sweetness on the self-same bough. Spring, 321.

Together both, ere the high lawns appeared Under the opening eyelids of the Morn, Iyc. 25-26.

"Oft at the blush of dawn
"I trod your level (4) Music, 30-31.

Toward he aven's descent had sloped his westering wheel. Lyc. 31. When Dan sol to slope his wheels began , 1 Cast. Ind. I,5I6.

Thee, Shepherd, thee the woods and desert caves, Lyc. 39 . $c_{\text {Hark, how each giant-oak, and desert }}$ cave,

(1) Bard, 23

Or with the tangles of Neaera's hair? Lyc. 69.

Play with the tangles of her hair; Lib. Ode. 140 .

Comes the blind Fury - -

Comes blind unrelenting fate,

Lyc. 75. 1) Cast. Ind. I, I65. Lyc. 77 .

- - - and touched my trembling ears:

---But still their trembling ears retained Cast. Ind.I, 172 

Smooth-sliding Mincius, crowned with vocal reeds,

Lyc. 86 .

Had silent slept amid the Mincian reeds;

(1) Cast. Ind. II, 463 .

That strain I heard was of a higher mood. -that strain was of a graver tone;

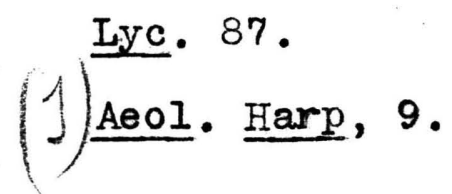

Next, $\frac{\text { Camus, }}{\text { slow, reverend sire, went footing }}$

Lyc. 103.

Or where old Cam soft-paces o'er the

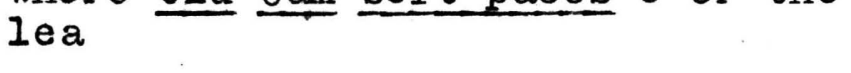

(1) Cast. Ind. II, $18 \%$

He shook his mitred locks, and stern be spake:-

Iyc. 112.

And mitred Fathers in long order go: (y) Music, 38.

Ye valleys low, where the wild whispers use

of shades, and wanton winds, -... Lyc. 136-137.

When wanton gales along the valleys + (C) or. Ec. I, 15.

To strew the laureate hearse where Iycid 1ies.

---and let me strew

The grave where Russell lies;

You lov'd her hills, and led her laureat band:

(1) sum. 1522-23. (2)

C) Simplic. 33

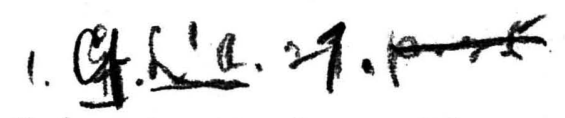

7. Cf. Music, 84, quoted above. 

Whether beyond the stormy Hebrides, Iyc. 156. Pours in among the stormy Hebrides- (T) Aut. 865.

With eager thought warbling his Doric lay: Iyc. 189. Temper'd to thy warbled lay. (y) Prog. Poes. 26.

Of bright aerial spirits live insphered Nigh spher'd in heav'n -.com. 3. (C) Poet. Char. 66 .

\section{To tread low-thoughted vice be neath
their feet,}

Com. 6 .

(1) Aut. 967 .

To lay their just hands on that golden key Com. 13. Thine too the se golden keys,..... (f) Prog. Poes. 91.

The nodding horror of whose shady brows $\underline{\text { Com. } 38 .}$ The rocks, and nodding groves rebellow to the roar,

What never yet was heard in tale or song, Com. 44. What never yet was sung in mortal lay 1 least. Ind. I, 275.

From old or modern bard, in hall or bower. Com. 45. No more, in hall or bow'r, (2) + (C) Simplic. 37.

1. Cf. also Lyc., 33: "Tempered to the oaten flute",

2. Spenser has, "Merrily masking both in boure and hall." Astrophe I and Stella, 28. 

Well knows to still the wild winds when they roar,

Com. 87 .

"Thro' the wild waves as they roar (y) Music, 89.

In a light fantastic round. Com. 144 .

Love fram'd with Mirth a gay fantastic round;

Passions, 90

The star that bids the shepherd fold

Com. 93.

For when thy folding-star arising shews

(C) Even. 21

- - - - - - When once her eye

Hath met the virtue of this magic dust,

With magic dust their eyne he tries to blind;

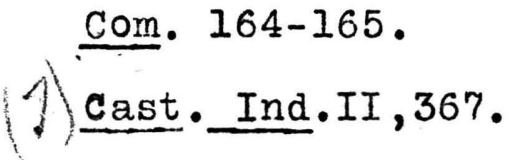

Rose from the hindmost wheels of Phoebus' wain.

Com. 190.

The whilst in ocean Phoebus dips his wain,

Cast. Ind. I, 268

Thou hovering angel girt with golden wings, (1) Com. 2I

And Hope enchanted smil'd, and wav'd her golden hair.

(Cassions, 38

By slow Meander's margent green,

Com. 232 .

And on the margent of some limpid flood,

Happiness, 90

Disporting on they margent green $\quad$ J Eton Col. 23.

1. Reference to Hope. 

Where the love-lorn nightingale

Nightly to thee her sad song mourneth well: Com. 234-235.

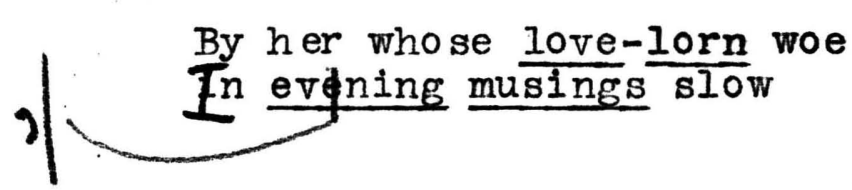

+ CSimplic. 16-17.

- - what time the laboured ox

Com. 291.

-............ Drooping, the labourer-ox Win. 240.

I know each lane, and every alley green, Com. 311.

Its vistas opens, and its alleys green. Spring, 515.

- - - - - - some gentle taper,

of some clay habitation, visit us

With they long levelled rule of streaming light, Com. 340 .

Nor visited by one directive ray

From cottage streaming or from airy hall.

- - - - - a taper's ray,

Aut. .1148-1149.

Did to a lonely cot his steps decoy: MCast. Ind.II, 49-51. ?

Or sound of pastoral reed with oaten stops, om. 345 .

If ought of oaten stop, or pastoral song,

C. Even. 1 .

Within the navel of this hideous wood, Com. 520 . Midst the green navel of our isle, (C) Lib. Ode, 90.

Iike stabled wolves,- - - -

Com. 534 .

- - - -a stabling now for wolves 1 Lib. III, 370. 

That draw the litter of close-curtained sleep. Com. 554 .

or $\frac{\text { curtain'd }}{\text { ev'ry future view. }}$. (c) Poet. Char. 76 .

The wonted roar was up amidst the woods - - - while the wonted roar is up, (T) sum. 949.

At last a soft and solemn-breathing sound Com. 555. Parent of sweet and solemn-breathing $/ 4$ prog. Poes. 14.
airs,

The pillared firmament is rottenness, Com. 598. 7 This pillardd earth so firm and wide, $(0$ Lib. Ode, 76.

He with his bare wand can unthread thy

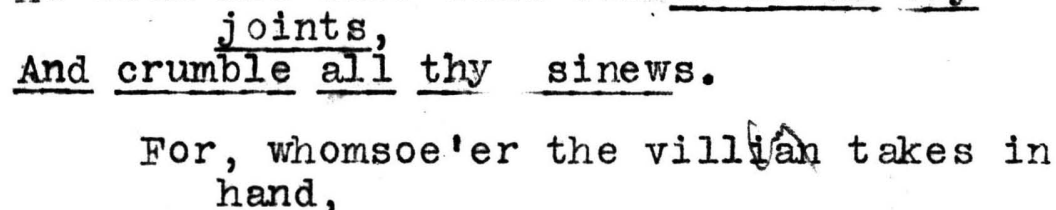
Their joints unknit, their sinews melt apace;

What need a vermeil-tinctured lip for that, Com. 752 . With vermeil-cheek and whispers soft MViciss. 3.

Love-darting eyes, or tresses like the morn?

1. Cast. Ind. I, 199-200.

The wish of each love-darting eye; Com. 753. (1) Boet. Char. 8.

1. Sylvester al so has "love-darting". 

Obtruding false rules pranked in reason's garb.

Com. 759 .

Where Science, prank'd in tissu'd vest,

(c) Mann. 15.

Under the glassy, cool, translucent wave, Com. 861.

With many a cool translucent brimming flood

(1) Aut. 888 .

With pliant. arm thy glassy wave?

(1) Eton Col. 26 .

From a thousand petty rills,

Com. 926 .

A thousand rills their mazy progress

(1) Prog. Poes. 4

The Graces and the rosy-bosomed Hours

Lo! where the rosy-bosom'd Hours,

Com. 986.

- - - The rosy-bosomed spring.

(1) sp. Ode, 1 .

Mspring, 1009.

About the cedarn alleys fling (1)

Com. 990

Peeping from forth their alleys green: (C) Passions, 77.

Up in the broad fields of the sky.

Com. 979 .

Oft as he traversed the cerulean field,

(1) Cast. Ind. I, 527.)

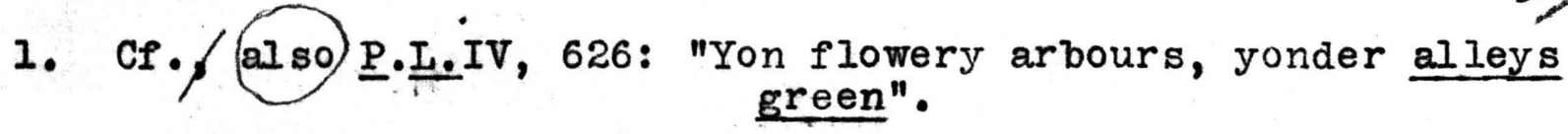





\section{(e.37 next) 38 .}

The white pink, and the pansy freaked with Iyc. 144. jet,

Or beanteous freaked with many a mingled hue,

f) Win. 814 .

And yet anon repairs his drooping he ad, Iyc. 169. "To-morrow he repairs the golden flood, Bard, 137.

Who, ripe and frolic of his full-grown age, com. 59. - - - would play the shapes

of frolic fancy,- - - (1) win. 610-611.

And, in thick shelter of black shades imbowered,

Com. 62 .

Close hid his castle 'mid embowering
trees,

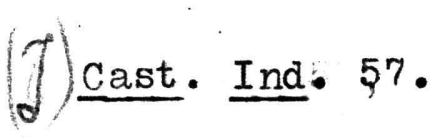

Stirs up among the loose unlettered hinds, Com. 174. $7 \begin{aligned} & \text { Their name, their years, spelt by } \\ & \text { th unlettergd Muse, }\end{aligned}$

By the rushy-fringè bank, Beside some water's rushy brink (f) Sp. Ode, 15.

A consideration of the passages quoted reveals the fact that Milton's minor poems, other than II Penseroso and I'Allegro, have fumished eighty-three lines that have been paralleled by Thomson, Gray, and Collins. Twenty-five of the se parall- 

Which deepest spirits and choicest wits desire.

Vac. Exer. 22.

Had arm'd with spirit, wit, and satire 1 tong story, 30.

But in their glimmering orbs did glow,

(2). Nat. Ode. 75 .

And from their dewy orbs the conscious stars

(1) Lisy's Cat, 11 .

Pillows his chin upon an orient wave, Nat. Ode, 231.

And drew the roseate breath of orient day;

(1) Cast. Ind. II, 84

- $\bar{c}^{-}-\overline{-}$-this best sun from orient Cast. Ind.II,I37.

We drove a-field, - - - $\quad$ Iyc. 27 .

How jocund did they drive their team afield!

$$
4 \text { Elegy, } 27
$$

Towards heaven's descent had sloped his westering wheel.

Iyc. $3 I$.

And Wfight, who checks the west'ring tide;

(C) Iib: Ode., 84

2. This reference is also to "stars". 
The verbal indebtedness in the passages that follow is less clear, but familiarity on the part of the Romanticists with Milton's poems probably suggested them.

Which deepest spirits and choicest wits

Had arm'd with spirit, wit, and satire 1 Long Story, 30.

\section{th}

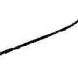

But in their glimmering orbs did glow,

(2). Nat. Ode. 75 .

And from their dewy orbs the conscious stars

1) Lisy's Cat, 1 I.

Pillows his chin upon an orient wave, Nat. Ode, 231.

And drew the roseate breath of orient
day;

- - ${ }_{\text {climes, }}$-this best sun from orient Neast. Ind.II,I37.

We drove a-field, - - - Iyc. 27 .

How jocund did they drive their team afield!

4 Elegy, 27.

Towards heaven's descent had sloped his westering wheel.

Iyc. 31.

And Wfight, who checks the west'ring tide;

Lib. Ode. , 84

1. This reference is also to "stars". 



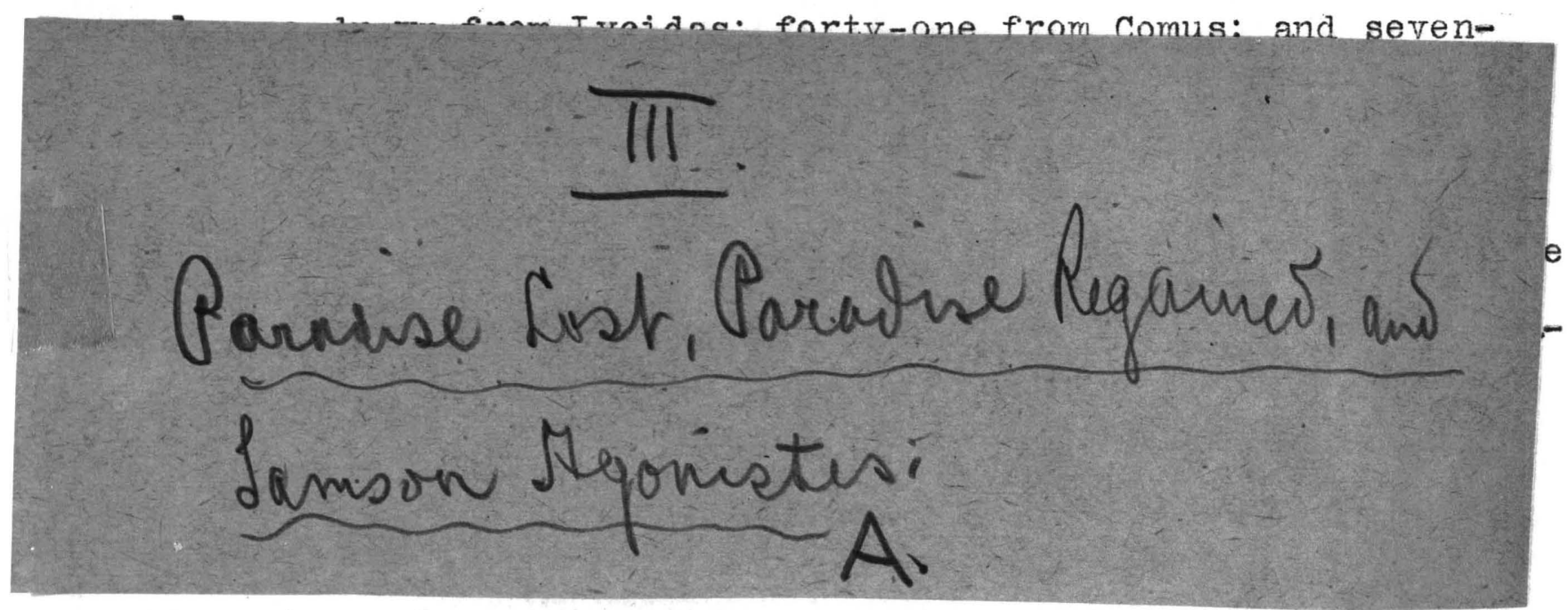

these three Romantic poets.

In adamantine chains and penal fire, P. I. , I, 48 . Bound in thy adamantine chain (e) Advers. 5 .

- - - - -round he throws his baleful eyes, P. I., I, 56. But Ruin spreads her baleful fires * around. (c) Or.Ec. IV, 52

Hail, horrors! hail,

Hail, horrors, hail!

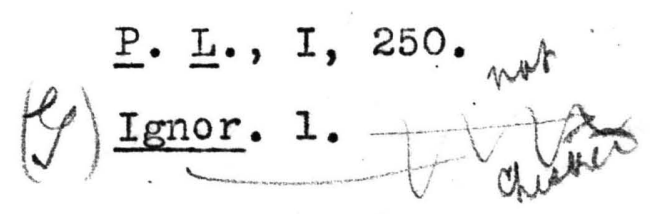

Rivers, or mountains, in her spotty globe. ․․ I., I, 291. Turn'd to the sun direct,her spotted disk-

1) Aut. 1091 .

Of locusts, warping on the eastern wind, $\underline{\text { P. I. }, ~ I, ~} 34 I$.

- - - insect armies warp

Keen in the poison'd b

T) Spring, 121-122. 
els are drawn from Lycidas; forty-one from Comus; and seventeen from the Sonnets, Nativity Ode, and other minor poems. Even granting that some of the less imnediate parallels are of little weight, the passages indicate that Milton's influence upon Thomson, Gray, and Collins is apparent in more than "occasional phrases".

An examination of Milton's later poems adds weight to the evidence that Milton influenced the verbal expression of these three Romantic poets.

In adamantine chains and penal fire, P. I. , I, 48 . Bound in thy adamantine chain

- - - - round he throws his baleful eyes, $\underline{\text { - }}$. I., I, 56. But Ruin spreads her baleful fires around. (c) Or.Ec. IV, 52

Hail, horrors: hail,

Hai 1, horrors, hai 1:

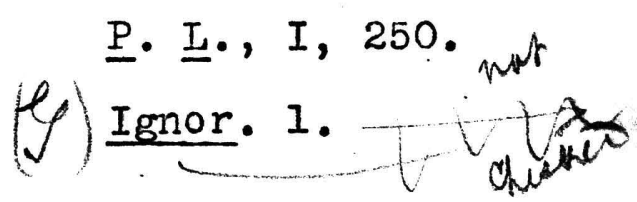

Rivers, or mountains, in her spotty globe. ‥ I., I, 291. Turn'd to the sun direct,her spotted disk1) Aut. 1091.

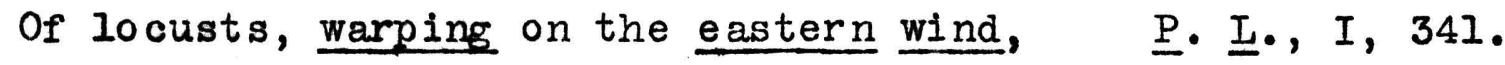
- - - Insect armies warp Keen in the poison'd breeze; 

Shone like a meteor streaming to the wind, $\underline{\text { P. }}$ I., I, 537 .

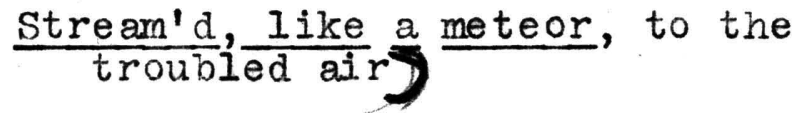

With orient colours waving: - - -

With orient hues, unborrow'd of the Sun: (f) Bard, 20

$\underline{\text { P. }}$ I. $, I, 546$.

(f) $\operatorname{Prog} \cdot$ Poes. 120

$\underline{P} \cdot \underline{I} \cdot, I, 601-602$.

Sat on his faded cheek, - . -

And on their brow sat every nation's cares.

(1) Cast. Ind.I,625.

P. I. , I, 717 .

(y) Iong story, 5 .

Where thro' the long-drawn isle and fretted vamit

(1)
(1) Elegy, 39.

- - - - - - - - - and confer

Their state-affairs:

‥ I. , I, 774-775.

The happy people in their waxen cells

Sat tending public cares, - . - -

T) Aut. 1176-77.

- - - when the scourge

Inexorably, and the torturing hour,

$\underline{P} \cdot \underline{I} \cdot, I I, 90-91$.

Whose iron scourge and tortiring hour,

(3)

1. Cf., Hamlet, II, 2, 312.

2. Reférence to "bees".

3. Cf. Aeneid, VIII, 429.

g) Advers. 3 

Scout far and wide into the realm of Night, ‥ I., II, 133. And drags me from the realms of night? (y) Des. Odin, 30.

Should inte mitted vengeance arm again

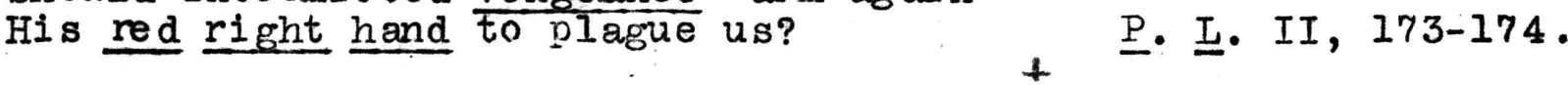

Whilst Vengeance, in the lurid air,

$>$ Iifts her red arm, exposqd and bare:(C) Fear, 20-21.

The sound of blustering winds, - - + $\quad$ P. I., II, 286. But when chill blust'ring. winds,--- (C) Even. 33.

- - - - - - and ride the air

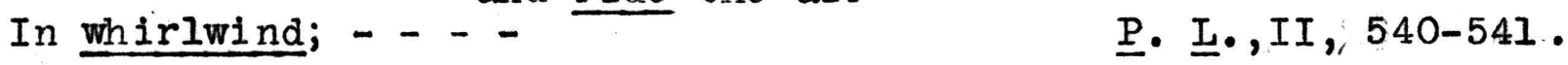

Riding sublime, - On the whirlwind's wing fil Hymn, 18-19.

Medusa with Gorgonian terror guards $\underline{\text { P. I., II, } 611 .}$

Not in thy Gorgon terrors clad, (1) (b) Advers. 35.

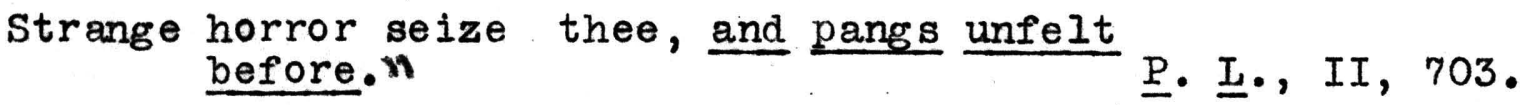

With pangs unfelt before, unpitied and alone. (f) Advers. 8.

Hail, holy $\frac{\text { Iight }}{\text { first-born! }}$ : fspring of Heaven $/$ P. I., III, I

of all material belngs first and best; (1) Sum. $90-91$.

Cf., Ov1d, Met., IV, 80I; and Val. Flac., VI, 175. 

In the dun air sublime, - - - - - - Night, (I) $\quad$ P.I., III, 71-72. Dun night has veil'd the solemn view.(C) Death Thom. 34.

Not far off Heaven, in the precincts of Iight,

$\underline{P} \cdot \underline{I} \cdot$, III , 88 .

Left the warm precincts of the che arful day,

(9) Elegy, 87 .

Rolls o'er Elysian flowers her amber stream!

P.I., III , 359 .

Or where Mâander's amber waves

(2) $/ f)$ Prog. Poes. 69.

Dark with excessive bright thy skirts appear,

P. I. , III , 380 .

He saw; but blasted with excess of light,

(g) Prog. Poes. 101

$\overline{-}-\overline{-}-\overline{-}-\overline{-o n}$ Imaus bread,
Whose snowy ridge the roving Tartar
bounds,

$\underline{P} \cdot I_{-}$, III, $431-432$.

- - - - - -from Imaus stretched

Athwart the roving Tartar's sullen bounds;(ी Aut. 783-784.

- - - - wings he wore

Of many a coloured plume - - -

$\underline{P} \cdot I_{-}$, III , 64I-642.

CWares in the eye of Heav'n her many-colour'd wings.

(y) Bard, $12 \%$

1.Cf., (also) P.I., VI, 10-11: "Obsequious $\underset{\text { her hour }}{\text { Darness }}$ enters, till

2.Cf., (aIso) P. R., Book III, 288: "There Susa by Choaspes, amber stream," 

Of a steep wilderness, whose hairy sides

With thicket overgrown, grotesque and wild, Access denied; - . - . -

High on some cliff, to heav'n up-pil'd, clief, to hear'n

of rude access, of prospect wild, $+(C)$ Poet. Char, 55-56.

Blossoms and fruits at once of golden hue, …․, IV, 148.

Greened all the year; and fruits and

blossoms blush'd $(1)$ Spring, 320.

Appeared, with gay enamelled colours mixed;

$\underline{P} \cdot I_{-}, I V, 149$.

All glossy gay, enamelied all with gold,

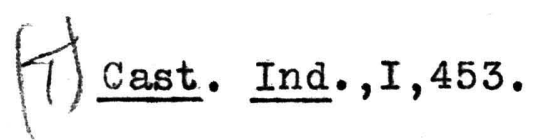

At one slight bound high overleaped all bound

Far overleaps all bound, - - $\left(\int\right)_{\text {Trans. }}^{\text {P.I. IV }, 18 I .}$.

Watching where shepherds pen. their flocks at eve, $\underline{P} . \underline{.} ., I V, 185$

Till late at silent eve she penn'd the fold. (c) or. Ec. III, 14

- - - - - - the crisped brooks,

With mazy error under pendent shades P. I. , IV , 237-239. - - - - - - and the warbling maze of the wild brooks (1) Cast. Ind. I, 430-431. 

- - - - - but Nature boon

- - - - - boon nature gave,

All that boon nature could luxuriant pour

o Nature boon, - - - -
$\underline{P} . I_{.}, I V, 242$.

(1) Cast. Ind. I,513.
(1) Lib. II, 98 .

(C) Mann. 71 .

- - - - - and where the unpierced shade

Imbrowned the noontide bowers. P. I. , IV , 245-246.

$\frac{\text { Shade }}{\text { the deepening }} \frac{\text { over }}{\text { country } \text { shade, }}$

Imbrown, - - -

(1) Aut. 951-952.

- - - - with summer half imbrowned, (T) Cast. Ind. , I, 16.

And woods imbrown the steep, - - ( T) Cast. Ind., II, 243

Its glooms embrown, - - + + (C) Poet. Char. 60.

Of some irriguous valley spread her store, P.I.,IV,255.

See where the winding vale its lavish

stores,

Irriguous spreads. - . . -

T) Spring, 493-494.

Truth, wisdom, sanctitude severe and pure- $\underline{P} \cdot \underline{I} ., I V, 293$.

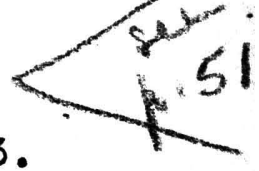

And Truth severe, - . - ( 1 ) Bard, 127.

$\frac{\text { Yielded, with coy submission, modest pride, }}{\text { And sweet, reluctant, amorous delay. }}$ 年, IV, 310-3ll.

Wi th fond reluctance, yielding modesty,

l) Agrip. 179

Reluctant pride, and amorous faint consent;
C) Verses, 19.

Il With modest pride to grace thy youthful brow

ly Music, 83. 

Eyed them askance, - - - $\underline{P} \cdot I_{-}, I V, 504$.

Whom meaner Beauties eye askance, $\quad(f)$ Long Story, 27.

She all night long her zmorous descant sung: $\underline{P} . I_{-}, I V, 603$.

The Birds in vain their amorous Descant joyn;

(g) Rich. West, 3 .

Sweet is the breath of Morn, $\underline{P} \cdot I ., I V, 641$

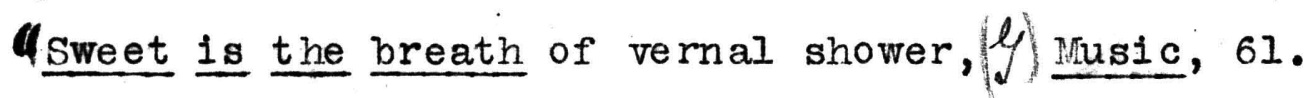

How nature paints her colours, - - $\underline{P} \cdot \underline{I} \cdot, \mathrm{V}, 24$. - - - - - whose colours clear Richly paint the vernal year:

(y) Prog. Poes. $89-90$

Shadowy sets off the face of things $\underline{P} \cdot \underline{.} ., \mathrm{V}, 43$.

To close the face of things. -...-. (T) Sum. 1654.

- - - - - that crown'st the smiling morn P. I. . V, 168 .

In vain to me the smileing Mornings shine,

- - . - - "Adam, Earth's hallowed mould, ${ }^{+}$. I. I.,V, 321. Returns to deck their hallow'd mold, (C) Ode in 1746, 4.

- - - from off the boughs each morn

We brush the mellifluous dews - - $\quad \underline{P}$. I. , V, 428-429. Brushing with hasty steps the dews awaylElegy, 99. 

From midst a golden cloud, - - - P. I. VI, 28 . Foremost and leaning from her golden $(y)$ Music, 65.
cloud P. I. VI, 328 .

And writhed him to and fro convolved;

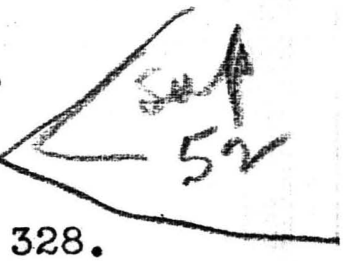

- - - - - his sportive lambs

This way and that convolved, - - (1) Spring, 835-837.

"Now, when fair Morn orient in Heaven

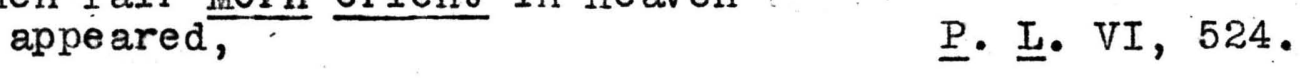

The radiant Morn resum'd her orient
pride;

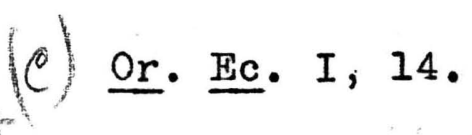

On the crystalline sky, in sapphire

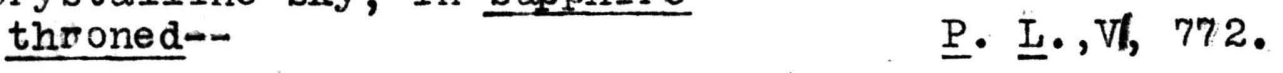

And plac'd her on his sapphire throne, (Poet. Char. 32.

He on the wings of Cherub rode sublime

P. I. VI, 77 I.

Nor second He, that rode sublime

Upon the seraph-wings of Extasy,

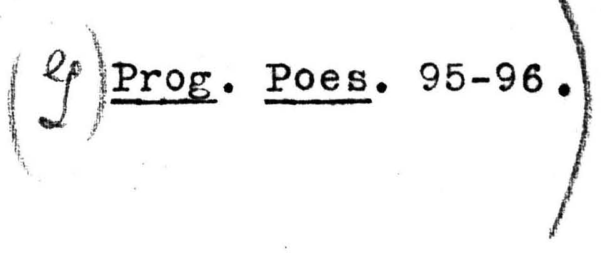

- - - - - but on the watery calm

His brooding wings the spirit of God out-
spread,
P. I.VII , 234-235.

And broods o'er Aegypt with his wat'ry wings, 

- - - - - -where rivers now

Stream, and perpetual draw their humid train.

Where rushy Camus" - - -

Perpetual draws his humid train of mudf/Ignor. 3-4.

Ye softer floods, that lead the humid maze

(T) Hymn, 51 .

And drink the Iiquid Iight, - - -

Melts into air and liquid light.
$\underline{\mathrm{P}} \cdot \mathrm{I} ., \mathrm{VII}, 362$.
(1) $(y)$ Viciss. 16

- - - - -Part, single or with mate,

Graze the sea-weed, their pasture, and through groves

of coral stray, or, sporting with quick

Show to the sun the ir waved coats dropt with gold,

Some IIghtly o'er the current skim,

Some shew their gaily-gilded trim

Quick-glancing to the sun.

lf) $\mathrm{sp} \cdot$ Ode, $28-30$

- - - - ard spread their painted wings, $\underline{\text { p.I. }}$. VII, 434. No painted plumage to display:

(2) (lf) Sp. Ode, 47 .

- - - the crested cock, whose clarion sounds

P. I. VII, 443 .

The cock's shrill clarion, - - (3) ylegy, 19.

1. Lucretius has, "Iiquidi fens luminis", V, 282.

2. Virgil has, "Pictisque plumis", Aenjd, IV, 525.

3. Cf., Elegy, 19-20 with I'Allegro, 53-56. 

- - - - - - part, huge of bulk,

Wal lowing unwieldy, enormous in their gate,

Tempest the ocean. There Ieviathan,

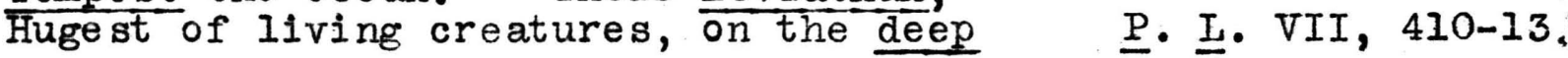

More to embroil the deep, Ieviathan

And his unwieldy train in dreadful

sport

Tempest the loosened brine; --

(T) Win. 1014-1016.

- - -the swan, with arched neck

Between her white wings mantling proudly, rows

Her state with oary feet; - -

P. I. VII, 438-40.

- - - The stately-sailing swan

Gives out his snowy plumage to the gale;

And, arching proud his neck, with oary feet

1) Spring, 776-778.

Easy my unpremeditated verse,

P. I. IX, 24 .

Poured forth his unpremeditated strainf Cast. Ind. I,607.

- - -four times crossed the car of Night $\underline{\text { P. }}$ I. IX, 65.

Till dusky night, advancing in her car f Beauty, 19.

- - - - that breathed

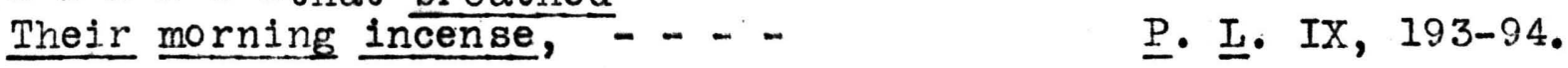

The breezy call of incense-breathing Morn,

Elegy, 17.

Veiled in a cloud of fragrance, where she

Half-spied, so thick the roses bushing round

P. I. IX, 425-26.

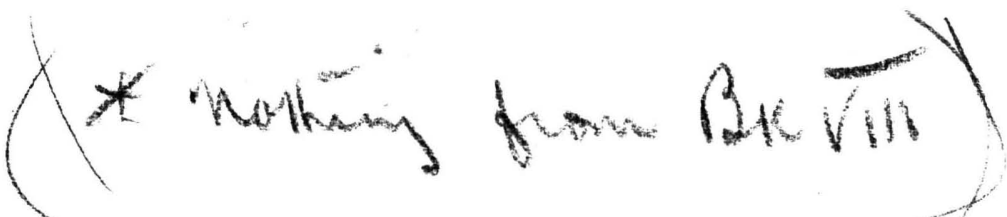



of shadowy roses, - in - shower

The smell of grain, or tedded grass, - $\quad$ P. I. IX, 450 .

Wide flies the tedded grain; -.. (T)

With feathered cincture, naked else and wild,․․ I. IX,1ll\%.

Their feather-cinctured Chiefs, and dusky Loves.

(y) Prog. Poes. 62.

The field pavilioned with his guardians bright;

P. I. XI, 215.

Amidst the bright pavilion'd plains, (C) Lib. Ode, 105.

With carcasses and arms the ensanguined

field

P. $\underline{\text { I. }} \mathrm{XI}, 654$.

Wading thro' th' ensanguin'd field:

l. Fatal Sisters 30.

-. - - ensanguined man

(T) Spring, 339.

With dreadful faces thronged and fiery arms. ‥ I. XII, 644. - Thronged with aerial spears, and steeds of fire,

T.Aut. 1118.

They, hand in hand, with wandering steps and slow,

P. I. XII, 648 .

With solemn steps and slow

(f) Music, 36 .

- - - At every step

Solemn and slow $\ldots$

T) Sum. 519-520.

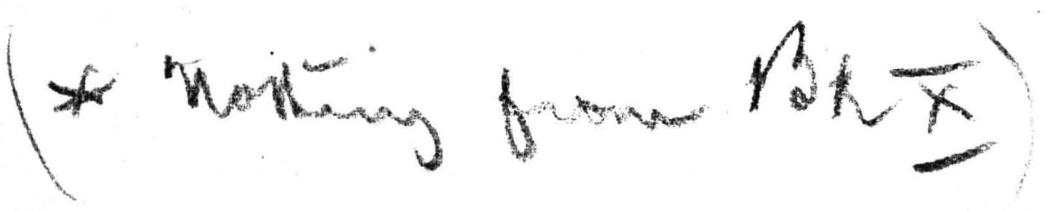



Sharp sleet $\frac{\text { of }}{\text { face }}$ arrowy showers against the Iron-sleet of arrowy shower

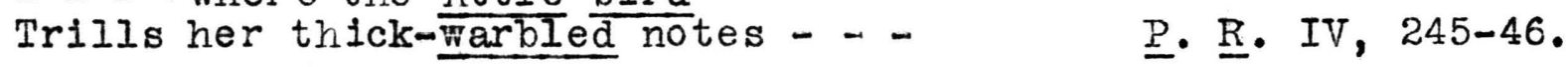

The Attic warbler pours her throat, $(g)$ sp. Ode, 5.

of bees' industrious murmur, - - -

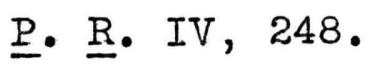

Yet hark, how thro' the peopled air

The busy murmur Elows!

$(y)$ sp. Ode, 23-24.

Through the soft air the busy nations

fly,

(T) Spring, 506

-...- - till Morning fair

Came forth with pilgrim steps, in amice

gray;

$\underline{P} \cdot \underline{R} . I V, 426-27$.

There Honour comes, a pilgrim grey, (C) Ode in 1746, 9.

Though in this uncouth place), if old
respect,

S. Agon. 333.

- - - these, by ties confirmed,

Of old respect and gratitude, are

I Agrip. 113-114.

I dread him not, nor all his giant brood, S. Agon. 1247 .

But Mother of the giant-brood! y) Des. Odin, 86. 
Sharp sleet of arrowy showers against the

$$
\begin{array}{ll}
\text { Iron-sleet of arrowy shower } & \text { P. R. III, 324. } \\
\text { Ires } & (y) \text { Fatal sisters, } 3 .
\end{array}
$$

- - - where the Attic bird

Trills her thick warble d notes - . $\quad$ P. ‥ IV, 245-46.

The Attic warbler pours her throat, $(\mathcal{G})$ sp. Ode, 5 .

Of bees' industrious murmur, - - $\quad$ ‥ ‥ IV, 248 .

Yet hark, how thro' the peopled air

The busy murmur Elows!

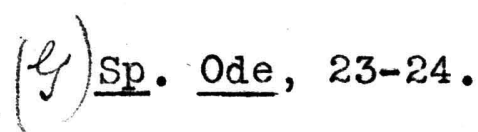

Through the soft air the busy nations fly,

(T) Spring, 506

....- - till Morning fair

Came forth with pilgrim steps, in amice

$$
\text { gray; }
$$

P. R. IV, 426-27.

There Honour comes, a pilgrim grey, (C) Ode in 1746, 9.

Though in this uncouth place), if old
respect,

S. Agon. 333.

- - - these, by ties confirmed,

Of $\frac{\text { old }}{\text { yourespect }}$ and gratitude, are

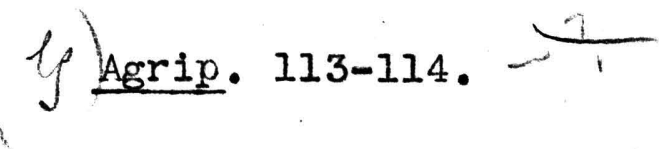

I dread him not, nor all his giant brood, S. Agon. 1247
fes. Odin, 86

But Mother of the giant-brood!

It cannot be definitely determined, but there is a possibility that Milton's later poems had some influence upon 

Thomson, Gray, and Collins when they wrote these passages.

Awake, arise, or be forever fallen! arise, or be forever fallen!
Goddess! awake, arise! alas, my fears f I Ignor. 250 .

Rifled the bowels of theirmother earth P. I. I, 687 . Deep in the bowels of the pitying earth sum. 870 .

Environed, wins his way; - P. I. II, 1016.

In gliding state she wins her easy way f prog. Poes. $3 q$

All path of man or beast that passed that way. $\underline{P} \cdot \underline{I} \cdot I V, 177$. From all the roads of earth that pass
there by:

- - - - and the Hours in dance

Led on the eternal Spring. - . - - - and in her train

Leads on the gentle Hours; - -
P. I. IV, 267-68.

Spring , 1035-36.

- - - wove with Gordian twine

His braided train, - - P. I. IV, 348-49. In braided dance their murmurs join'd, Cpoet. Char. 48.

- - when he impregns the clouds P. I. IV, 500 .

The fruitful rock itself, impregned by thee, 

Till the sun paint your fleecy skirts with

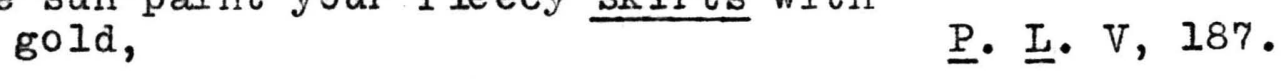

Sits in yon we stern tent, whose cloudy

$$
\text { skirts, (I) (C) Even. } 6 \text {. }
$$

- - - - Like Maia's son he stood,

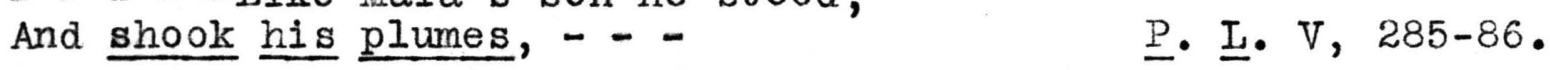

Shook thous and odours from his dewy wings.

(c) Passions, 94

From skirt to skirt a fiery region, - ... ‥ ‥ VI, 80 .

Descending slow their glitt'ring skirts unróll?

(f) Bard, 106

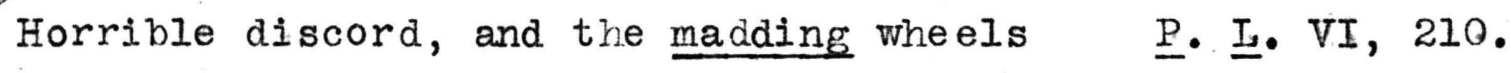

Far from the madding crowd's ignoble strife,

Rocks, waters, woods, and, by the shaggy

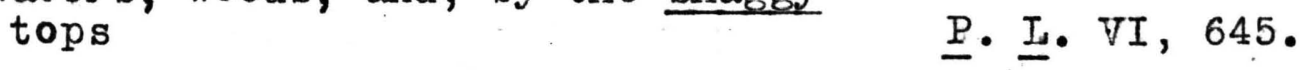

As down the steep of Snowdon's shaggy
side

On the crystalline sky, - - -

She eyes the clear crystalline well, (4 yiciss. 55.

1. Cf., also, "The fluid skirts of that same watery cloud,"

2. Note that Milton and Gray each accent "crystalline" on the penult. Milton has the same accent for this word

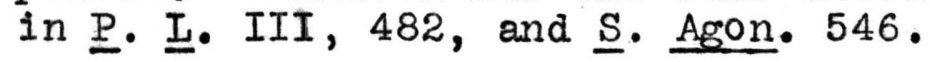





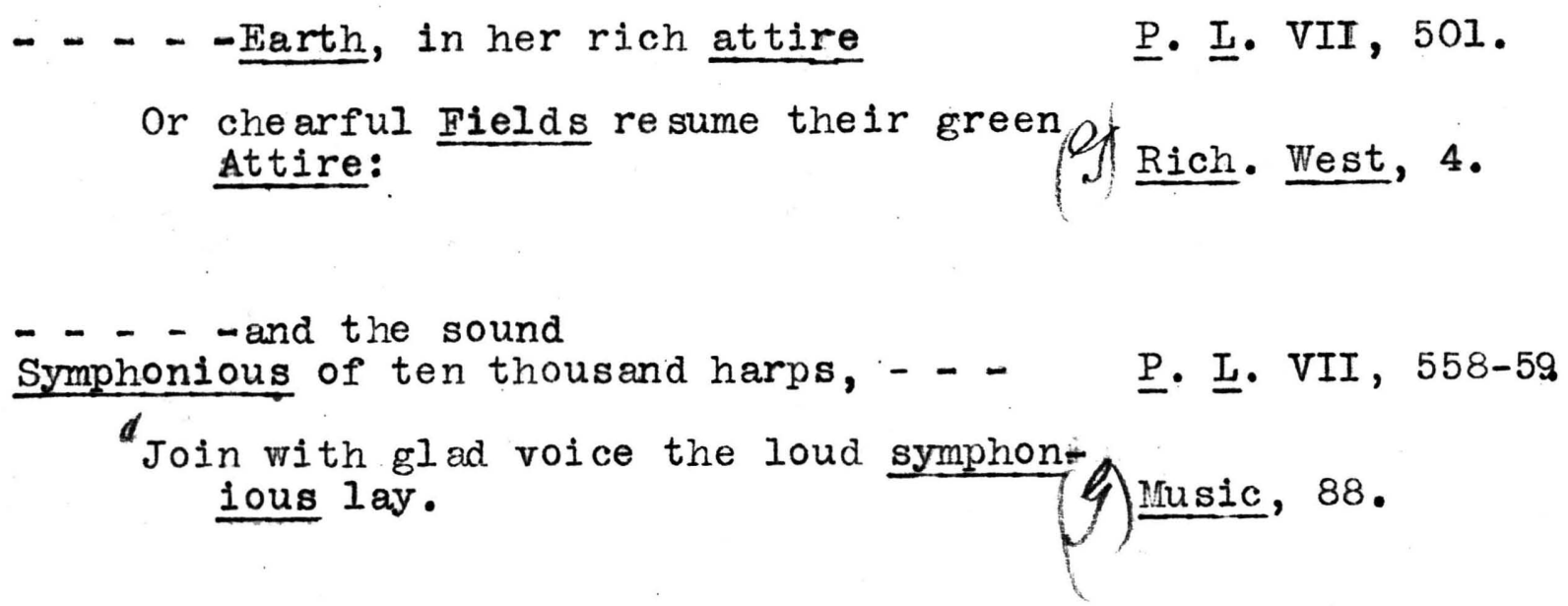

And over them triumphant Death his dart

Shook, - - - ․․ I. XI, 491 . And o'er the nations shook her conquering dart:

Thomson, Gray, and Collins have borrowed from at le ast eighty-two Iines of Paradise Iost, from three Iines of Paradise Regained, and from two lines of Samson Agonistes. Milton's entire poems have furnished these Romanticists with two CP hundred twenty-four partially or completely borrowed lines. This is no inconsider able number when it is recalled that Collins and Gray, in particular, have such a small body of poems.

Iiterary critics have pointed out that the primary aspect of the creative genius of a poet lies in his power in combining words, especially adjectives and nouns. They have shown, also, that the parts of speech that especially give color, life, and spirit to poetry are the adjective and the 

verb. An examination of the parallel passages reveals the fact that approximately sixty-five per cent of the words borrowed from Milton by Thomson, Gray, and Collins are adjectives. Ten per cent are adjectives and nouns in juxtaposition; as "eastern gate", "fallows grey", "barons bold", "haunted stream", Fifteen per cent of the borrowed words are verbs. The remaining ten per cent are participles, adverbs, etc.

This would seem to indicate that, in so far as verbal expressions are concerned, these Romanticists are indebted to Milton primarily in adjectives and secondarily in verbs. If it be true that adjectives and verbs are of such fundamental importance, the verbal indebtedness of the Romanticists to Milton is of a character that connotes a fundamental and farreaching influence. Since Milton was practically ignored until the Romantic revival, these words were not handed on from poet to poet; in very few cases does there seem to have been a common source. Therefore, Thomson, Gray, and Collins hust have drawn these verbal expressions directly from Milton. Such a large number of parallel lines demonstrates that Milton's influence upon Thomson, Gray, and Collins wain very extensive. Their verbal indebtedness to Milton is primarily in the matter of adjectives and verbs,--the parts of speech that most of all indicate the fervor, the vividness, the power of the poetic imagination. Milton's influence upon Thomson, Gray, and Collins was of the deepest kind. 



\section{PART IV.}

\section{MILTON'S INELUENCE IN CONCEPTION}

Il Penseroso is the beginning and The Elegy Written in a Country Churchyard is the culmination of that phase of English literature known as the "Poetry of Ifelancholy" or "Greveyard Poetry". Its classical parallel is to be found in the elegiac poetry of Catullus, Propertius, and Tibullus. The Latin elegiac feeling was somewhat different; love was at the basis of its melancholy. In Propertius, it is a passion, but the "gravitas" of the Roman character has deepened into gloom; in Tibullus, love is tender affection tinged with melancholy. In Catullus, there is a prevailing chord of sadness, a mournful minor key. Even his gay dedication of his yacht, which declares no pinnace could outstrip her, ends with the sad reflection, "portion and parcel of the past". (1). In his most ardent bursts of passion, he cannot put aside the thought of the darkness of death and the certainty that

Suns will rise and set again: But for us, when once doth wane This poor page ant's little light, We must sleep in endless night. (2),

The general atmosphere and the literary tools of the se Roman poets are found in II Penseroso and in the melancholy reflec-

1. Sed haec prius fuere. (IV,23)

2. Soles occidere et redire possunt: Nobis cum semel occidit brevis lux Nox est perpetua una dormienda. $(\mathrm{V}, 4-6)$. 3. Cf., Terrell, R. Y. -Iatin Poetry, H. M. \& Co., 1895. 

tions of the Romanticists.

Il Penseroso furnished the model and the material for this contemplative, thoughtful, scholarly, and romantic group of poets. Milton's picture of the ideal day of the thoughtful man, who at twilight in company with Contemplation takes great delight in the song of the nightingale, that "most musical, most melencholy" of birds; or, away from the haunts of men with the moon as his only companion, listens to the sound of the curfew as it is borne across "some wide-watered shore"; or, yet again, spends the entire night with his favorite philosophers, tragedians, and romantic poets, leaving them at dawn to retire to groves where the bee with "honeyed thigh" and the meiodious sound of running water entice the "dewyfeathered" sleep--this ideal day of an ideal youth was the source of the imaginative conceptions and the inspiration of that group of men who were pioneers in the Romantic movement. Fletcher's,

Nothing's so dainty sweet as lovely Melancholy was a theory accepted by the entire group. Joseph and Thomas Warton, and Mason followed Milton so closely that their works seem almost like parody. Mason wrote two poems called II Bellicoso and Il Pacifico that are direct imitations of Milton. Joseph Warton wrote odes To Fancy, To Solitude, To the Nightingale that recall Milton's poems at every turn. Thomas Warton imitated him in The Pleasures of Melancholy, On the First of April, and On the Approach of Summer. Dodsley's Miscellanies 

abound in odes on Simplicity, Innocence, Fancy, Melancholy, Solitude, Contemplation, and allied themes. The poetical machinery, of Milton in II Penseroso furnished all the material necessary for these men; grots, caverns, brooksides, ivied woods, firelight rooms, curfew bells, twilight with its beetle and bat, solitude, the darkening vale, moonlight ruins, appear in one form or another in all their poems.

Although Thomson, Gray, and Collins have reminders of Milton on almost every page, the imitations in conception are not so openly manifest, and the flights of imagination which owe their impulse to Milton were probably unconscious. Yet brooding, placid, cultivated minds like those of Thomson, Gray, and Collins are the very places where we should expect to find second-hand ideas. They have not named any of the ir poems II Bellicoso or II Pacifico; but melancholy was a "pleasing fit to them". II Penseroso of fered many suggestions to their contemplative minds;again and again, melancholy conceptions are met that seem to have had Milton's lyric as their inspiration. A comparison of some of the passages from the poems of Thomson, Gray, and Collins with II Penseroso tends to establish this st atement. 

Hence, vain deluding Joys,

The brood of Folly without $f$ ather bred!

How little you bested,

or fill the fixed mind with all your toys!

Dwell in some idle brain,

And fancies fond with gaudy shapes possess,

As thick and numberless

As the gay motes that people the sun-beams,

Or likest hovering dreams,

The fickle pensioners of Morpheus' train.

But, hail! thou Goddess sage and holy!

Hail, divdne st Mel ancholy!

Who se saintly visage is too bright

To hit the sense of human sight,

And therefore to our we aker view

o'erlaid with black, staid Wisdom's hue;

Come, pensive Nun, devout and pure,

Sober, steadfast, and demure,

All in a robe of darkest grain,

Flowing with majestic train,

And sable stole of cypress lawn

Over they decent shoulders drawn.
Begone all mirth! Begone all sports and play, (I)
Hail, mildly ple asing solitude, Companion of the wise and good; But from who se holy, piercing eye, The herd of fools and villians fly. (2)

But sacred be the veil that kindIy clouds

A light too keen for mortals;
Thou who with hermit he art Disdain'st the wealth of art, And gauds, and pageant weeds, and trailing pall, But com'st a decent maid In Attic robe array'd, 0 chaste, unboastful nymph, to thee I call!

1. Pastoral, Thir. Cory., 19.

2. Solitude, $\overline{i-4}$.

3. Iib. III, 561-562.

4. Simplic. 7-12. 

Come; but keep thy wonted state,

With even step, and musing gait,

And looks commercing with the skies,

Thy rapt soul sitting in thine eyes:

There held in holy passion still,

Forget thyself to marble, till

With a sad leaden downward c ast

Thou fix them on the earth as $f$ ast.

And join with thee calm Peace and Quiet,

Spare Fast, that oft with gods doth diet,

And hears the Muses in a ring

Ave round about Jove's altar sing;

And add to the se retired Iei sure,

That in trim gardens takes his pleasure;

But, first and chiefest, with the e bring

Him that yon soars on golden wing,

Guiding the fiery-wheeled throne,

The Cherub Contemplation;

And the mute silence hist along,

'Less Philomel will deign a song,

In her sweetest saddest plight,

smoothing the rugged brow of Night,

While Cynthia checks her dragon yoke

Gently o'er the accustomed oak.
With eyes uprais'd as one inspir'd,

Pale Melancholy sate retir'd, And from her wild sequester'd se at,

In notes by distance made more sweet,

Pour'd thro' the mellow horn her pensive soul;

And, dashing soft from rocks around,

Bubbling runnels join'd the sound;

'Ihro' glades and glooms the mingled measure stole:

or o'er some haunted stream with fond delay

Round an holy calm diffusing,

Jove of peace and lonely musing,

In hollow murmurs died away. (1)

Ye brown o'er-arching Groves,

That Contemplation loves,

Where willowy Camus lingers with delight !

Oft at the blush of $d$ awn

I trod your level lawn,

Oft woo'd the gleam of Cynthia silver-bright

In cloisters dim, far from the haunts of Folly,

With Freedom by my side, and soft-ey'd Melancholy. (2)

\footnotetext{
1. Passions, 57-68.

2. Music, $27-34$.
} 

Sweet bird, that shunn'st the noise of folly,

Most musical, most melancholy!

Thee, chauntress, oft the woods among

I woo, to hear thy evensong;

And, missing thee, I walk unseen

On the dry smooth-shaven green,

To behold the wandering moon,

Riding ne ar her highest noon,

Iike one that had been led astray

Through the he aven's wide pathless way,

And oft, as if her head she bowed,

Stooping through a fleecy cloud.

Oft, on a plat of rising ground,

I hear the far-off curfew sound,

Over some wide-watered shore,

Swinging slow with sullen roar;

Or, if the air will not permit,

Some still removed place will. fit,

Where glowing embers through the room

Teach light to counterfeit a gloom,

Far from ali resort of mirth,

Save the cricket on the he arth,

Or the beliman's arowsy charm

To bless the doors from nightly harm.

Or let my lamp, at midnight hour,

Be seen in some high lonely tower,
In Georgia's land, where Tefflis' tow'rs are seen,

In distant view along the level green,

While ev'ning dews enrich the glitt'ring glade,

And the tall forests cast a

$$
\text { longer shade, (1) }
$$

The changing moon he clad with silver light,

To check the biack dominion of the night:

High through the skies in silent st ate she rides,

And by her rounds the fleeting time divides.

Or, if he meditate his wish'd e scape,

To some dim hill that seems uprising near,

In the wild depths of Winter, while without

The ceaseless winds blow ice, be my retreat

Between the groaning forest and the shore

Beat by a boundless multitude of waves, -

A rural, sheltered, solitary scene,

Where ruddy fire and beaming tapers join

To cheer the gloom. There studious let me sit,

And hold high converse with the mighty dead,-

Sages of ancient time, as gods revered,

As gods beneficent, who blessed mankind

1. Or. Ec. III, 1-4. 2. Ps. CIV, 66-69. 3. Pop. Super. 112-13. 

Where I may oft outwatch the Bear,

With thrice great Hermes, or unsphere

The spirit of Plato, to unfold

What worlds or what vast regions hold

The immortal mind that hath forsook

Her mansion in this fleshly nook;

And of those demons that are found.

In fire, air, flood, or unde rground,

Whose power hath a true consent

With planet or with element.

Thus, Night, oft see me in thy pale career,

Till civil-suited Morn appear,

Not tricked and frounced, as she was wont

With the Attic boy to hunt;

But kerchieft in a comely cloud,

While rocking winds are piping loud,

Or ushered with a shower still,

When the gust hath blown his fill,

1. Win. 426-439.

2. Even. 33-34.
With arts and arms, and humanized a world.

Roused at the inspiring thought, I throw aside

The long-lived volume; and deepmusing hail

The sacred shades, that slowlyrising pass

Before my wondering eyes. First Socrates,

(I)
But when chill blust'ring winds, or driving rain,

Forbid my willing feet, be mine the hut (2) 

Ending on the rustiing leaves,

With minute-drops from off the eaves.

And, when the sun begins to fling

His flaring beams, me, Goddess, bring

To arched walks of twilight groves,

And shadows brown, that Sylvan loves,

of pine, or monument al o ak,

Where the rude axe with heaved stroke

Was never heard the nymphs to daunt,

or fright them from their hallowed haunt.

There, in close covert, by some brook,

Where no profaner eye may look,

Hide me from day's garish eye,

While the bee with honeyed thigh,

That at her flowery work doth sing,

And the waters murmuring,

With such consort as they keep,

Entice the dewy-feathered sleep.

And let some strange mysterious dream

Wave at his wings, in airy stream.

Of lively portraiture displayed,

Softly on my eyelids laid;

And, as I wake, sweet music breathe

Above, about, or underneath,

I. Cast. Ind. I,536.

2. Cast. Ind. I, 20.

3. Spring, 442-447.

4. Aut. 1030-1035.

5. Cast. Ind. I, 28-36.
To groves of pine and broad o'ershadowing oak;

Sleep-soothing groves, and. quiet lawns between;

- - -but when the sun

Shakes from his noon-day throne the scattering clouds,

Even shooting listless languor through the deeps,

Then seek the bank where flowering.elders crowd,

Where scattered wild the Iily of the vale

Its balmy essence breathes, - - (3)

Oh! be ar me them to vast embowering shades,

To twilight groves and visionary vales,

To weeping grottos and prophetic glooms,

Where angel-forms athwart the solemn dusk

Tremendous sweep, or seem to sweep, along, (4)

Joined to the prattle of the purling rills

Were heard the lowing herds along the vale,

And flocks loud bleating from the distant hilis,

And vacant shepherds piping in the dale;

And now and then sweet Philomel would wail,

Or stockdoves 'plain amid the forest deep,

That drowsy rustled to the sighing gale;

Yet all these sounds yblent inclined all to sleep.

(5) 

Sent by some spirit to mortals good,

Or the unseen Genius of the wood.

But let my due feet never fail

To walk the studious cloister's pale,

And love the high embowed roof,

With antique pillars, mas sy-proof,

And storied windows richly dight,

Casting a dim religious light.

There let the pealing organ blow,

To the full-voiced quire below,

In service high and anthems clear,

As may with sweetness, through mine ear,

Dissolve me into ecstasies,

And bring all Heaven before mine eyes.

And may at last my weary age

Find out the peaceful hermitage,

The hairy gown and mossy cell,

Where I may sit and rightly spell

Of every star that heaven doth

And every herb that sips (shew, the dew,

Till old experience do attain let some retreating cynic find

To something like prophetic strain.

The se pleasures, Melancholy, give;

And I with thee will choose to Iive.

Meantime, unnumbered glittering streamlets played,

And hurled everywhere their waters sheen;

That, as they bickered through the sunny glade,

Though restless still themselves, a lulling murmur made.

Rich windows that exclude the light,

And passages that lead to nothing.

(2)

Assembled men, to the deep organ join

The long-resounding voice, oftbreaking clear

At solemn pauses through the swelling bass;

And, as each mingling flame increases each,

In one united ardour rise to heaven.

There let me oft, retir'd by day,

In dreams of passion melt away,

Allow'd with thee to dwell:

There waste the mournful lamp of night,

Till, virgin, thou again delight To hear a British shell!

Those oft-turn'd scrolls I leave behind:

The sports and I this hour agree

To rove thy scene-full world with thee!

(5)

1. Cast. Ind. I, 24-27. Cf., also Cast. Ind. I, 380-387; II, 23-24; I, 345-358; Aut. 969-973; Sum. 9714; Spring, 459-62; Country Iife, 5-12.

2. Iong story, 7-8.

3. Hymn, 84-86.

4. Pity, 37-42

5. Mann. 75-79. 

The study of II Penseroso in its conceptional influence upon Thomson, Gray, and Collins is meant to be suggestive rather than exhaustive. There are many passages in the poems of these Romanticists that recall the conceptions which Milton has given expression to in II Penseroso. The twentyone passages that have been quoted will serve to indicate the very considerable influence which this Iyric had upon Thomson, Gray, and collins.

While Miltonic conceptions are more abundant in Thomson, Gray, and Collins where there is evidence of the Melancholy Iiter ature", they may also be found in other connections. For the sake of convenience, passages suggested by Milton have been grouped under the following somewhat arbitrary headings.

\section{Physical Nature}

- - - -ere the odorous breath of morn

Awakes the slumbering leaves, - - -

Arc. 56-57.

And odorous sweets shall load the balmy gales;

Past. Dav. Th. 24

The winds, with wonder whist,

Smoothly the waters kissed,

Whispering new joys to the mild Ocean,

Nat. Ode. $66-68$.

While, whispering pleasure as they

fly,

Cool Zephyrs through the clear blue sky

Their gathered fragrance fling.

(I) Sp. Ode, 8-10

1. Cf., also I'A. 116 and P. I. IV, 156-159. 

The lonely mountain o'er, And the resounding shore, A voice of weeping heard and loud lament; Nat. Ode, 181-183

Where each old poetic Mountain Inspiration breathed around;

Prog. Poes. 73-74

So, when the sun in bed,

The flocking shadows pale

Troop to the infernal jail,

Each fettered ghost slips to his several grave,

And the yellow-skirted fays

Fly after the night-steeds,

Nat. Ode, 229-236

Night, and all her sickly dews,

Her spectres wan, and Birds of boding cry,

He gives to range the dreary sky:

Prog. Poes. 49-5I

Oft listening how the hounds and horn

Cheerly rouse the slumbering morn,

From the side of some hoar hill,

Through the high wood echoing shrill:

I: A. $\quad 53-56$.

The breezy call of incense-breathing Morn,

The swallow twitt'ring from the strawbuilt shed,

The cock's shrill clarion, or the echoing horn,

No more shall rouse them from their lowly bed.

Elegy, $17-20$.

And every shepherd telis his tale

Under the hawthorn in the dale.

I'A. $67-68$.

The Shepherd, in the peaceful dale, Brit. 136.

The shepherd tells his transport to the dale;

Prince Wales, 16 

Towers and battlements it sees

Bosomed high in tufted trees,

Add ancient seats, with venerable o aks

Fmbosom'd high, - - -

When the merry bells ring round,

And the jocund rebecks sound

Meantime the song went round; and dance and sport,

The melting voice through mazes running,

From Helicon's harmonious springs

A thousand rills their mazy progress take:

(I)
I'A. 77-78.

Iib. V, 52-53.

I'A. 93-94.

Spring, 248 .

I'A. I42.

Prog. Poes. 3-4.

That, like to rich and various gems, inlay The unadorned bosom of the deep;

com. 22-23.

Full manv a gem of purest $r$ ay serene, The dark unfathom'd caves of ocean bear:

Elegy, 53-54.

And see, like gems, her laughing train, The little isles on ev'ry side!

Iib. Ode, 80-8I.

Ere the blabbing eastern scout,

The nice Morn on the Indian steep,

From her cabined loop-hole peep,

And to the tell-tale sun descry

our concealed solemnity.

Com. 138-142.

And soon, observant of approaching day,

The meek-eyed morn appears, mother of dews,

At first faint-gleaming in the dappled east;

Till far o'er ether spreads the widening glow,

And from before the lustre of her face

White break the clouds away.

Sum. 46-51.

1. Cf. Pindar, $01 . \mathrm{II}, 62,229$. 

- - - -till the moon

Peeps through the chambers of the fleecy east,

Enlightened by degrees, and in her train

Ieads on the gentle hours;

Spring, $1032-36$

Oft have we seen him at the peep of dawn

Elegy, 98.

Wherefore did Nature pour her bounties forth

with such a full and unwithdrawing hand, Covering the earth with odours, fruits, and flocks,

But man, whom Nature formed of milder clay,

With every kind emotion in his heart,

And tamt alone to weep--while from her lap

She pours ten thousand delicacies, herbs

And fruits, as numerous as the drops of rain

Spring, 348-352.

By the rus,y-fringed bank,

Where grows the willow and the osier dank, Com. 890-891.

Where'er the rude and moss-grown beech

o'er-canopies the glade

Beside some waters rushy brink

Sp. Ode, $13-15$.

'Sing, Heavenly Muse', that, on the secret

of oreb, or sinai, didst inspire

That shepherd who first taught the chosen seed

In the beginning how the heavens and earth

Rose out of Chaos:

P. I. I, 5-10.

As when of old (so sung the Hebrew bard) 

Light, uncollected, through the chaos urged

Its infant way; nor order yet had drawn

His lovely train from out the dubious gloom.

Aut. $732-735$.

Deeming some island, oft, as seamen tell, With fixed anchor in his scaly rind, Moors by his side under the lee, while night

Invests the sea, and wished morn delays.

$\underline{P} \cdot \underline{I} \cdot I, 205-08$.

Ill fares the bark with trembling wretches charged,

That tossed amid the floating fragments,

Moors beneath the shelter of an icy isle,

While night o'erwhelms the sea, and horror looks

More horrible.

Win. 1005-1008.

- - - - as when the sun new-risen

Looks through the horizontal misty air

Shorn of his beams, or, from behind the moon

In dim eclipse, disastrous twilight sheds. ‥ I. I, 594-97.

- - - - - - - - - - -the sun

Sheds weak and blunt his wide-refracted $r$ ay;

Whence glaring oft, with many a broadened orb,

He frights the nations. Indistinct on earth,

Seen through the turbid air, beyond the life

Opjects appear;

Aut. 721-726.

Hail, holy light, offspring of Heaven first-born!

Or of the Eternal coeternal beam

May I express thee unblamed?

P. I. III, I-3. 

With them would search if Nature's boundless frame

Was called late-rising from the void of night,

or sprung eternal from the Eternal Mind,

Win. 575-577.

Portable gold, when, with one virtuous touch,

The arch-chemic sun, so far from us remote,

produces, with terrestrial humour mixed,

Here in the dark so many precious things

of colour glorious and effect so rare?

P. I. III, 608-12

The mineral kinds confess thy (1)

mighty power.

Effulgent hence the veiny marble

shines;

Hence labour draws his tools;

Sum. 134-136.

o thou(I) that, with surpasing glory crowned,

Look'st from thy soul dominion like the god

Of this new World -

P. I. IV, 432-34.

Great source of day, best image here below

of thy creator, ever pouring wide,

From world to world, the vital ocean round, -

Hymn, 66-68.

Sabean odours from the spicy shore

Of Araby the Blessed,

P. I. IV, 162-63.

- - - - Arabia cannot boast

A fuller gale of joy than liberal thence

Breathes through the sense,

Spring, 499-501.

By Sargis' banks or Irwan's shady grove;

On Tarkie's mountain, catch the cooling gale,

Or breathe the scents of Aly's flow'ry vale:

Or. Ec. IV, 44-46.

1. Reference to "sun". 

- - - - - as the ranks ascend, Shade above shade, a woody the at re Of stateliest view. P. I. 140-142.

The theatre's green height and woody wall

Trans. Stat. 14 .

Southward through Eden went a river large,

Nor changed his course, but through the shaggy hill

Passed underneath ingulfed; for God had thrown

That, mountain, as his garden-mould high raised

Upon the rapid current, which, through veins

of porous earth with kindly thirst updrawn,

Rose a fresh fountain, and with many a rill Watered the garden;

Some sages say that, where the numerous wave

For-ever lashes the resounding shore,

Sucked through the sandy stratum every way,

The waters with the sandy stratum rise;

Nor stops the restless fluid, mounting stili,

Though oft amidst the irriguous vale it spir ings;

But to. the mountain courted by the sand,

That leads it darkling on in faithful maze,

Far from tine parent main it boils again

Fresh into day, - - . - - -

Spring, 743-755.

- - - - -fresh gales and gentie airs

Wrispered it to the woods, and from their

wings

Flung rose, flung odours from the spicy shrub, 

I feel the gales, that from ye blow

A moment ary bliss bestow,

As waving fresh their gladsome wing, Eton Col. 15-17.

As one who, long in populous city pent,

Where houses thick and sewers annoy the

air,

Forth'issuing on a summer's morn, to breathe

Among the pleasant villages and farms

Adjoined, from each thing met conceives

delight -

The smell of grain, or tedded grass, or kine,

Or dairy, each rural site, each rural sound- P. I. IX, 445-45I.

- - - - -Now from the town

Buried in smoke, and sleep, and noisome damps,

Oft let me wander o'er the dewy fields

Where freshness breathes, and dash the trembling drops

From the bent bush, as through the verdant maze

Of sweet-briar hedges I pursue my walk;

or taste the smell of dairy;

Spring, 100-106.

II. Animals, Birds, Insects, etc.

To he ar the lark begin his flight,

And, singing, startle the dull night, I'A. 4l-42.

The early larks their morning tribute

And, in shrill notes, salute the blooming day.

Morn. Count. 3-4.

What time the grey-fly winds her sultry horn,

Iyc. 28.

Save where the beetle wheels his droning flight, 

O Nightingale that on yon bloomy spray

Warblest at eve, when all the woods are still,

Thou with fresh hope the lover's heart dost

fill.

While the jolly hours lead on propitious

May.

Thy liquid notes that close the eye of day

First heard before the shallow cuckoo's bill,

Portend success in love.

Son. I, I-6.

Lend me your song, ye nightingales; oh pour

The mazy-running soul of melody

Into my varied verse; while I deduce,

From the first note the hollow cuckoo sings,

The symphony of Spring, and touch a theme

Unknown to fame-the passion of the groves.

Spring, 575-580

The Attic warbler pours her throat, Responsive to the cuckow's note,

Sp. Ode, 5-6.

A multitude like which the populous North

Poured never from her frozen loins to pass

Rhene or the Danaw, when her barbarous

sons

Came like a deluge on the South, and spread

Beneath Gibraltar to the Iibyan sands.

P. I. I, 35I-55.

Wide o'er the spacious regions of the north

That see Bootes urge his tardy wain,

A boisterous race, by frosty caurus pierced,

Who little ple asure know and fear no pain,

Prolific swarm.

Win. 834-838.

- - - - There Ieviathan,

$---$

- - - - and at his gilis

Draws in, and at his trunk spouts out,

a sea.

P. I. VII, 412-16.

'Tis there that Leviathan sports and plays,

And spouts his water in the face of day;

Ps. CIV, 97-98. 

- - There the eagle and the stork

On cliffs and cedar-tops their eyries build.

P. I. VII , 423-24.

Forth from his eyrie rous'd in dread,

The rav'ning eagle northward fled:

or dwell in willow'd me ads more near,

With those to whom thy stork is dear; Lib. Ode, 53-56.

III. Man - His Occupations and Characteristics

So may some gentle Muse

With lucky words favour my destined urn,

And as he passes turn,

And bid fair peace to be my sable shroud! Iyc. 19-22.

- -the muse, ambitious of thy name

To grace, inspire, and dignify her song,

Would from the public voice they gentle e ar

Awhile engage.

Spring, 9-12.

With stories told of many a feat,

How Faery Mab the junkets eat.

She was pinched and pulled, she said; I'A. 101-103.

Me antime the village rouses up the fire;

While, well attested and as well believed,

Heard solemn, goes the goblin story round,

Till superstitious horror creeps o'er all;

Win. 616-620.

Such sights as youthful poets dream

On sumer eves by haunted stream.

I'A. 129-130.

You caninat bar my constant feet to trace

The woods and lawns by living stream at eve:

Cast. Ind. II, 23-24 

And all their friends and native home forget,

And sweet oblivion of vile earthly care, -

Com. 76 .

Cast. Ind. I,242.

- - - Me thought it was the sound

Of riot and ill-managed merriment,

Such as the jocund flute or gamesome pipe

Stirs up among the loose unlettered hinds, When, for their teeming flocks and granges fuil,

In wanton dance they praise the bounteous Pan,

Com. $171-176$

While, loose to festive joy, the country round

Ialghs with the loud sincerity of mirth,

Shook to the wind their cares.

Aut. 1221-23.

- - - - what time the laboured ox

In his loose traces from the furrow came, Com. 291-292.

The plownan homeward plods his weary way,

Elegy, 3.

Joyous the impatient husbandman perceives

Relenting nature, and his lusty steers

Drives from their stalls to where the we 1l-use d plow

Iies in the furrow loosened from the frost.

Spring, 34-37.

Far from the cheerful haunt of men and herds,

Com. 388.

Far from the madding crowd's ignoble strife,

Elegy, 73.

No goblin or swart faery of the mine,

Com. 436 

And goblins haunt, from fire, or fen, Or mine, or flood, the walks of men! Fear, 62-63.

Such are those thick and gloomy shadows damp

Oft seen in charnel-vaults and sepulchres, Iingering and sitting by a new-made grave, Com. 470-472.

The disappointed prowlers $f a l l$, and dig

The shrouded body from the grave; o'er which,

Mixed with foul shades and frighted ghosts, they howl.

Win. $411-413$

- - - - - a certain shep̄herd lad,

of small regard to see to, yet well skilled

In every virtuous plant and healing herb Com. 619-621.

He came, the bard, a little Druid wight

Of withered aspect; but his eye was keen,

With sweetness mixed.

Cast. Ind. II , 289-291.

- - See, here be all the pleasures

That fancy can beget on useful thoughts,

And first behold this cordial julep here,

That flames and dances in his crystal

bounds,

With spirits of balm and fragrant syrups

mixed.

Com: 668-674.

And everywhere huge covered tables stood,

With wines high-flavoured and rich viands crowned;

Whatever sprightly juice or tasteful food

On the green bosom of this earth are found,

Cast. Ind.I, 298-301.

- - - a spot like which perhaps

Astronomer in the Sun's Iucent orb

Through his glazed optic tube yet never saw. $\underline{\text {. }}$ I. III,588-590. 

- - - -or astronomic tube,

Far stretching, snatches from the dark abyss;

I. Newt on, 61 .

- - - - -though both

Not equal, as their sex not equal seem;

For contemplation he and valour formed,

For softness she and sweet attractive grace; $\underline{P}$. $\underline{L}$. IV, 295-99.

With equal virtue formed, and equal grace -

The same, distingui she d by their sex alone:

Hers the mild lustre of the gloomy morn,

And his the radiance of the risen day.

Sum. $1173-76$.

- - - -which implied

Subjection, but required with gentle sway,

And to thy just, thy gentle hand

P. I. IV , 307-308.

Mnsic, 85 .

Now Morn, her rosy steps in the eastern clime

Advancing, sowed the earth with orient pearl,

When Adam waked, so customed; for his sleep

Was aery light, from pure digestion bred,

And temperate vapours bland, which the only sound

of leaves and fuming rills, Aurora's $f$ an,

Iightly dispersed, and the shrill matin song

of birds on every bough.

P. I. V, I-8.

The first fresh dawn then waked the gladdened race

of uncorrupted man, nor blushed to see

The sluggard sleep beneath its sacred be am;

For their light slumbers gently fumed away,

And up they rose as vigorous as the sun, 

- - - -arms on armour clashing brayed

Heard ye the din of battle bray,
$\underline{P} \cdot-I \cdot V I, 208$.

Bard, 83.

The Angel ended, and in Adam's ear So charming left his voice that he awhile

Thought him still speaking, still stood fixed to hear;

P. $\underline{I} \cdot \operatorname{VIII}, 1-3$.

He ceased. But still their trembling ears retained

The deep vibrations of his 'witching song;

Cast. Ind.173-74.

- - - - - for nothing lovlier can be

found

In woman than to study household good,

P. I. IX, 232-33.

- - - -there to tend

Her household cares, a woman's best employment,

Agrip. 7-8.

Well-ordered home, man's best delight, to make;

And by submissive wisdom, modest skill, With every gentle care-eluding art,

To raise the virtues, animate the bliss,

Even charm the pains to something more than joy,

And sweeten all the toils of human life:

This be the female dignity, and praise. Aut. 603-609.

A bery of fair women, richly gay

P. I. XI,582.

Bevies of dainty dames, of high degree Cast.Ind. I, 632. 

IV. Moral, Ethical, and Abstract Conceptions

Sent down the meek-eyed Peace:

She, crowned with olive green, came softly siliding

Down through the turning sphere,

His ready harbinger,

with turtle wing the amorous clouds

dividing;

Nat. Ode, $46-50$

0 Thou, who bad'st thy turtles bear Swift from his grasp, thy golden hair, And sought'st thy native skies;

Peace, 1-3.

Such sweet compulsion doth in music lie, To lull the daughters of Necessity, And keep tunsteady Nature to her law, And the low world in measured motion draw

After the heavenly tune, which none can he ar

Of human mould with gross unpurged ear.

Arc. $68-73$

Aerial music in the warbling wind,

At distance rising oft, by small

degrees,

Nearer and'nearer came, till o'er the trees

It hung, and breathed such soul-dissolving airs,

As did, alas! with soft perdition ple ase:

Entangled deep in its enchanting snares,

The listening heart forgot all duties and

i. all cares.

Cast. Ind.I, 345-35I.

- - - they introduce

Their sacred song, and waken raptures high: $\underline{P}$. I. III, 368-69.

Or wak'd to extasy the living lyre. Elegy, 48.

- - - - - -his evil

Thou usest, and from them creat'st more good. 

From seeming evil still educing good, Hymn, 114 . (Educing good from ill) - - (1). Iib. IV, 702.

- - - most men admire

Virtue who follow not her lore. $\underline{P} \cdot \underline{R}: I, 482-483$.

Stern rugged Nurse! thy rigid lore

With patience many a year she bore: Advers. 13-14.

- - - - For Beauty stands

In the admiration only of weak minds

Led captive; cease: to admire, and all her plumes

Fall flat and shrink into a trivial toy,

At every sudden slighting quite abashed.

P. . $I I, 220-224$.

Who trust alone in beauty's feeble ray,

Boast but the worth Balsora's pearls display;

Drawn from the deep we own their surface bright,

But, dark within, they drink no lustrous iight:

Or. Ec. I, 29-32.

- - be not over-exquisite

To cast the fashion of uncertain evils; Com. 359-360.

Yet ah! why should they know their fate?

Eton Col. 95.

She that has that is clad in complete steel, And, like a quivered nymph with arrows keen, May trace huge forests, and unharboured heaths

In famous hills, and sandy perilous wilds;

Where, through the sacred rays of chastity, Com. 421-427.

With thee be chastity, of all afraid, Distrusting all a wise suspicious maid, But man the most:

Or. Ec. I, 57-60

1. Cf., Henry V, IV, 1,4-5. 

Wherewith she tamed the brinded lioness And spotted mountain-pard,

Com. $443-444$

Even beauty, force divine! at whose bright giance

The generous lion stands in softened gaze,

Win. $405-406$

A thousand liveried angels lackey her, Driving far off each thing of sin and guilt, And in clear dream and solemn vision

Tell her of things that no gross ear can ḩear;

Com. $455-458$.

In waking wh1spers and repeated dreams

To hint pure thought and warm the favoured soul

For future trials fated to prepare; Sum. 528-530.

How charming is divine Philosophy!

Not harsh and crabbed as dull fools suppose, Com. 476-477.

- - - the enlightened few,

Whose godlike minds philosophy exalts, Sum. 1714-15.

Virtue may be assailed, but never hurt,

Surprised by unjust force, but not enthralled;

Yea, even that which Mischief meant most harm

Shall in the happy trial prove most glory.

But evil on itself shall back recoil,

And mix no more with goodness, when at last,

Gathered like scum, and settled to itself,

It shall be in eternal restless change

Self-fed and self-consumed.

Com. 589-597.

From virtue's fount the purest joys outwell,

Sweet rills of thought that cheer the conscious soul;

While vice pours forth the troubled streams of hell

The which, howe'es disguised, at last with dole

W11l through the tortured breast their fiery torrents roll.

Cast. Ind. II , 320-324.

On virtue can alone my kingdom stand,

For, lost the social cement of mankind, 

The greatest empires, by scarcefelt degrees,

will moulder soft away; till, tottering loose,

They, prone at last, to total ruin rush.

Iib. V, 93-97.

'Tis Virtue makes the bliss, where'er we dwell.

Or. Ec. I, 6 .

- - -taught the swains that surest bliss to find

What groves nor streams bestow, a virtuous mind.

Or. Ec. I, I2.

Or, if Virtue feeble were,

Heaven itself would stoop to her.

Com. 1022-23.

- - -to save the fall

Of Virtue struggling on the brink of Vice;

Sum. 526-527.

The song of Indolence (Castle of Indolence, I, 73-170) reminds one constantly of the dialogue between Virtue and Pleasure in comus.

Wherefore did Nature pour her bounties forth

With such a full and unwithdrawing hand;

Covering the earth'with odours, fruits, and flocks,

Thronging the seas with spawn innumerable,

But all to please and sate the curious taste?

And set to work millions of spinning worms,

That in their green shops weave the smoothhaired silk,

To deck her sons; and, that no corner might

Be vacant of her plenty, in her own loins

She hutched the all-worshipped ore and precious gems,

To store her children with. If all the world

Should, in a pet of temperance, feed on pulse,

Drink the clear stream, and nothing wear but frieze, 

The All-giver would be unthanked, would be unpraised,

Not half his riches known, and yet despised; Com. 710-723.

What, what is virtue, but repose of mind?

A pure ethereal calm that knows no storm,

Above the reach of wild ambition's wind,

Above those passions that this worls deform,

And torture man, a proud malignent worm!

But here, instead, soft gales of passion play,

And gently stir the heart; thereby to form

A quicker sense of joy;

Cast. Ind. I , 82-90.

v. Mythology and Superstition.

The Nymphs in twilight shade of tangled

thickets mourn.

Nat. Ode, 188.

The Muse has broke the twilight-gloom Prog.Poes. 56.

Next, Camus, reverend sire, went footing slow,

His mantle hairy, and his bonnet sedge, Lyc. 103-104.

Or where old Cam soft-paces o'er the lea

In pensive mood, and tunes his doric reeds,

The whilst his flock at large the lonely shepherd feeds. (I).

Cast. Ind.II, 187-189.

- - whila universal Pan,

Knit with the Graces and the Hours in dance,

Led on the eternal Spring.

P. I. IV, 266-68.

In graceful dance immingled, o'er the land,

1. Cf., al so Iyc. 23-26 and 186-189. 

Pan, Pales, Flora, and Pomona played: Cast.Ind.II;248-249.

Milions of spiritual creatures walk the Earth

Unseen, both when we wake, and when we

sleep:

All these with ceaselesis praise his works behold

Both day and night. How often, from the steep

of echoing hill or thicket, have we heard

Celestial voices to the midnight air,

Sole, or responsive each to other's note,

Singing their great creator!

P. I. IV, 677-84 .

Of Nature sing with us, and Nature's God.

Here frequent, at the visionary hour

When musing midnight reigns or silent noon,

Angelic harps are in full concert heard,

And voices chanting from the wood-crowned hill,

The deepening dale, or inmost sylvan glade, -

Aut. $555-560$

- - - Hell at last,

Yawning, received them whole,

P. I. VI, 874-75.

Down the yawning steep he rode,

That leads to Hela's drear abode.

Des. Odin, 3-4.

Who, with his soft pipe and smooth-dittied song,

And hush the waving woods;

Com. 86-88.

That hush'd the stormy main;

Bard, 30 .

And the gilded car of day

His glowing axle doth allay

In the steep Atlantic stream;

Com.95-97.

The whilst in ocean Phoebus dips his wain,

Cast. Ind. I, 268 . 

Me anwhile, welcome joy and feast, Midnight shout and revelry,

Com.102-103.

Comus, and his midnight crew, Music, 2.

Some say no evil thing that walks by night, In fog or fire, by lake or moorish fen,

Blue meagre hag, or stubborn unlaid ghost, That breaks his magic chains at curfew time, No goblin or swart faery of the mine

Com. $432-436$

In that thrice hallowed eve, abroad, When ghosts, as cottage maids believe, Their pebbled beds permitted leave; And goblins haunt, from fire, or fen, Or mine, or flood, the walks of men! Fear, 58-63.

At that still hour, when awful midnight reigns,

And none but wretches haunt the twilight plains;

Or. Ec. IV , 3-4.

- - - Without $h$ is rod reversed,

And backward mutters of dissevering power, com. 816-817.

Due sacrifice performed with barb'rous rites

of muttered charms, and solemn invocation,

Agrip. $62-63$

VI. God and Divinity.

- - -How oft amidst

Thick clouds and dark doth Heaven's all-ruling Sire

Choose to reside his glory unobscured,

And with the majesty of darkness round

Covers his throne, from whence deep thunders roar,

Mustering their rage, and Heaven resembles Hell!

- - -till Nature's King, who oft

Amid tempestuous darkness dwells alone, 

And on the wings of the careering wind

Walks dreadfully serene, commands a calm;

Then straight air, sea, and earth are hushed at once.

Win. 197-201.

- - - -since God is Iight,

And never but in unapproached light

Dwelt from eternity - dwelt then in thee, $\underline{P}$. I. III, 3-5.

How shall I then attempt to sing of Him,

Who, light Himself, in uncreated light

Invested deep, dweils awfully retired Sum. 175-177.

- - - Nor think, though men were none,

That Heaven would want spectators, God

want prai se.

P. I. IV, $675-76$.

And yet was every faltering tongue of Man

Almighty Father! silent in thy praise,

Thy works themselves would raise a general voice;

Sum. $185-188$.

- - - Upled by thee,

Into the Heaven of Heavens I have presumed, An earthly guest, and drawn empyreal air, ‥ I. VII, 12-14.

He pass'd the flaming bounds of place and time:

The living throne, the sapphire blaze,

Where angels tremble while they gaze,

He saw;

$\underline{\text { Prog. }}$ Poes.98-101

Yet doubt not but in valley and in plain

God is, as here, and will be found alike Present,

……XI, 349-35I.

Since God is ever present, ever felt,

In the void waste as in the city full; Hymn, 105-106. 

And his next son, for wealth and wisdom famed, The clouded ark of God, till then in tents Wandering, shall in a glorious temple enshrine.

P. I. XII, 332-335.

When He, who called with thought to birth.

Yon tented sky, this laughing earth

And dressed with springs and forests tall,

Poet. Char.25-27.

Thirty passages from Thomson, Gray, and Collins have been cited in which there are conceptions referring to nature that very probably owe their inspiration to Milton's poems; twenty-one passages referring to man, eighteen to mental, moral, and ethical conceptions, eleven to mythology and superstition, seven to the animal kingdom, six to Divinity. These parallels plus the parallels drawn from II Penseroso make a grand total of one hundred and fourteen passages in which Milton influenced Thomson, Gray, and Collins. Thirty-seven of the one hundred fourteen passages refer to some aspect of nature. It is worthy of note that when there was such a decided tendency to return to nature for descriptions of her, Thomson, Gray, and Collins should have drawn so many of their imaginative descriptions of $n$ at ure from Milton's poetry.

There are many passages in Thomson, Gray, and Colinns that do not suggest any one line or group of lines in Milton's poems, yet the general conception is felt to be Miltonic. Throughout the Ode on the Spring and the Eton College Ode, as well as in his Elegy, Gray is full of that melancholy brooding 

and twilight revery that is so suggestive of Milton. The Progress of Poesy (43-54) and the Ode on Vicissitude (34-36) also bear traces of Miltonic suggestions.

Collins' Ode on the Death of Mr. Thomson has many Miltonic reminiscences; and $h$ is Ode to Evening has about it a subdued twilight tone, a remoteness from men and human things, a pensive, evening musing, a serious melancholy that suggests Milton's lyrics. He was perhaps influenced by Milton in his Ode to the Manners $(1-18)$ and his Ode on Popular Superstitions (61-64); his picture of cheerfulness (Qde to the Passions; 69-74) would never have been drawn as it is had Collins not been familiar with I'Allegro.

Parts of Thomson's Seasons show many melancholy conceptions, some of which have a Miltonic tinge. (1) The speech of Corydon in A Pastoral. Between Thirsis and Corydon, upon the Death of Damon was in all probability inspired by Milton's Lycidas.

Ye muses, weep; your mirth and songs forbear, And for him sigh and shed a friendly tear.

He was your favorite, and by your aid

In charming verse his witty thoughts array'd;

He had of knowledge, leaming, wit, a store,

To it denied he still press'd after more.

He was a pious and a virtuous soul, And still press'd forward to the heavenly goal; He was a faithful, true, and constant friend, Faithful, and true, and const ant to the end. Ye flowers, hang down and droop jour heads, No more around your grateful odour spreads;

1. Cf., Aut. 1004-1007; 1030-1036; Surn. 344-351, etc., etc. 

Ye leafy trees, your blooming honours shed,

Damon forever from your shade is fled;

Fled to the mansions of eternal light,

Where endless wonders strike his happy sight.

I to some dark and giloomy shade will fly,

Dark as the grave wherein my friend doth lie;

And for his death to lonely rocks complain

In mournful accents and a dying strain,

While pining echo answers me again.

The passages cited appear to indicate that the "Melancholy Iiterature" of Thomson, Gray, and Collins had the II Penseroso of Milton as its inspiration. Milton appears also to have had marked influence upon the Romanticists in general ideas, intellectual activity, and imaginative conceptions in matters pertaining to the physical, mental, moral, and spir-itual worlds. It has been demonstrated to what an extensive degree and in what a fundamental way Thomson, Gray, and Collins borrowed from Milton in the matter of verbal expression. Their debt to him in the matter of conception is scarcely second to that of their verbal debt. It would seem justifiable to conclude that Milton's poems, his II Penseroso in particular, influenced the poetical conceptions of Thomson, Gray, and Collins to a very considerable degree. 



\section{PART V.}

\section{MILTON'S INFLUENCE IN FORM}

Since the evidence produced points to the conclusion that Thomson, Gray, and Collins were under the influence of Milton's language and thought to a very marked extent, it is to be expected that his form should also have had some influence upon them. It has been intimated that Pope and his school had made the heroic couplet so perfect in technique that the best poets soon lost interest in using.it. Just as the poets of the eighteenth century had found a satisfaction and delight in studying the language and conceptions of the heretofore despised English poets, so they turned to a thoughtful consideration of the form in which these men had expressed their ideas and feelings. In this respect, too, Milton was revived. The poets of the eighteenth century wrote lyrics and odes in his metres, and they strove to write his blank verse.

They did not have many models in blank verse. It came into the language $r$ ather late. The earliest specimen of English blank verse, that is, of the unrhyming five-foot iambic, is found in the translation of the second and fourth books of the Aeneid by Henry HOward, Earl of Surrey. This was done about 1540 and published in 1557. Important as this is historically, it is very poor poetically. The majority 

of the lines are rigidly decasyllabic, the verse-pause rarely varies from the end of the second foot, and there is a great preponderance of end-stopt lines. : The verses are not knit one to another; they are strung, not twisted.

Nicholas Grimoald added müch strength, elegance, and modulation to the blank verse of Surrey; Norton and Sackville applied it to the drama and increased the number of end-stopt lines. In 1587, Marlowe's Tamburlaine was published, a play whose verse sealed the fate of the rhymed drama. There are very few end-stopt lines in his work; his placing of the caesural pause shows considerable, though not the greatest variety; there is an extraordinary improvement in verse-accent. Rhymed couplets are still found occasionally. Hampered as he was by the popular taste and by popular custom, it was almost an impossibility to write an entire sentence without a rhyme.

The posibilities of blank verse revealed by Marlowe were employed, developed, and perfected by Shakespeare. Students of his dramas have discovered that those written before 1594 show an extensive use of rhyme and many end-stopt lines, and that the blank verse as a whole is marked by roughness and by Iimitations. (1) Yet there is an advancement over his prededessors in the use of double or feminine endings.

1. I. I. I. II, I, 13-34; II, I, 232-249. 

Shakespeare's gradual elimination of rhymed couplets, his increased use of run-on lines, his added number of weak endings, the gradual increase of the number of Alexandrine Iines, his mastery of the harmony and flow and rhythm of the verse- all this may be traced through the historical plays and the tragedies (I) and up to The Tempest and The Winter's Tale where dramatic blank verse is found in perfect organic form: Dramatic blank verse has never excelled the second scene of the first act of The Tempest nor parts of the fifth act.

Ye elves of hills, brooks, standing lakes, and groves, And ye that on the sands with printless foot Do chase the ebbing Neptune, and do fly him When he comes back; you demi-puppets that By moonshine do the green sour ringlets make Whereof the ewe not bites; and you whose pastime Is to make midnight mushrooms, that rejoice To he ar the solemn curfew, by whose aidWeak masters though ye be - I have bedimm'd The noontide sun, call'd forth the mutinous winds, And 'twixt the green sea and the azur'd vault

set roaring war;

The Tempest, V, 1, 33-44.

So Shakespeare, starting under a metrical bondage but little less troublesome than that of rhyming, perfected himself first within the limits of the individual line, until he reached at last the utmost freedom possible within those limits; then he set himself to remove the limits, broke down

1. Cf., I Henry I¥, I, 3, 1-302; Julius Caesar, III, 1, 254-275; III, 2, 78-234; Hamlet, I, 2, 129-159; Othel10, I, 3 , 158-168; IV, $2,47-64 ;$ Lear, I, $4,318-332 ;$ IV, 6 , $11-24$, etc. 

the $b$ arrier at the end of the line, and proceeded to compose less and less with the single verse as the standard, and more in rhythmical phrases of ever-varying length. (1).

Such was the condition and place of blank verse when Milton came to it. With few exceptions it had been used only by the dramatists. Shake speare had demonstrated for all time its power in that field. It remained for Milton's musical ear to compose the epic of English that should st and permanently with Homer's and Virgil's; he was to bring blank verse to its highest pitch of perfection as an instrument of narration. In his characteristic pugnacious spirit, and forgetting or disdaining his youthful poems, Milton has given us in the preface to his Paradise Jost his ideas in regard to rhyme; it is "no necessary adjunct or true ornament of poem or good verse, in longer works especially, but the invention of a barbarous age to set off wretched matter and lame metre..--Not without cause therefore, some both Italian and Spanish poets of prime note have rejected rime both in longer and shorter works, as have long since our best English tragedies; as a thing of itself, to all judicious ears, trivial and of no true musical delight; which consists only in apt numbers, fit quantity of sylabbles, and the sense variously drawn out from one verse into another; (2) not in the jingling sound of like endings, a fault avoided by the learned ancients both in poetry and in all good or atory."

1. Chambers: The Metre of Macbeth, 24.

2. The italics are mine. 

What Milton learned his blank verse from the dramatists seems clear. His early blank verse shows the influence of the Elizabethan age. Passages from Comus show Shakespe are's peculiarities. Although Milton began as a pupil of the dramatists, he escaped the decadent period; his ambitions and tendencies did not lead him to dramatic literature. When Milton began his blank verse, Suckling, Davenant, and their contemporaries were fast causing blank verse to degenerate into prose. At a time when it was yielding to decay, Milton used blank verse for epic poetry, and one by one gave up almost all the licenses the later dramatists had abused.

The variety necessary for a long poem he gains in various ways; principally, by varying the stresses in the Iine, their number, their weight, their incidence, letting them fall in the odd as well as the even syllables of the line; by varying the caesura, allowing it to fall usually towards the middle of the line, but occasionally, even after the first or ninth syllable, or by an interchange of feet, substituting a trochaic or an anapaestic for the iambic.

The striking characteristics of his blank verse, however, are two in number. One is his perfection in drawing the sense variouisly from one verise into another. "No other blank verse in the language exhibits such a masterly skill in the variation of ițs pauses." (I) His pauses coming at the end of a periodic

1. Corson; A Primer of English Verse, 192. 

group or at the end of a logical section of groups vary widely. They may come after or within the first, second, third, or fourth foot of a verse. Professor Corson has found five cases where the termination is within the fifth foot. (1). Paradise Lost, I, 59-69 or III, 80-89 exhibits in a very short space the variety of pauses. In the third line of the latter passage there are two pauses, in the last none, while the other, lines present the various possibilities.

Milton's other distinguishing characteristic is his versestanza. He seems to have obtained the suggestion from the classics. Homer's and Virgil's stanzas are not uniform; Milton's are based' upon them. But Homer never, and Virgil very rarely, attained the heights which Milton has scaled. Milton's skill in the use of the verse-stanza has rightly given him the praise of being the master of the grand style. No one else has ever succeeded so admirably in the harmonious and melodious grouping of verses into stanzas. The sonorous roll of his rhythm is unique. His stanzas are constructed upon the unifying action of feeling. They vary in length and in cadence with the power of thought and feeling which produces them; sometimes the wave of eloquence is sustained through a score of lines, again it may be expended within two or three. In any case, his musical ear was never content until he had produced waves of perfect melody and harmony. No one can read Paradise Lost without realizing that the voice is

1. Corson: Op. Cit., 193. 

kept in suspense over the theme and cannot come suddenly to a cadence. The reader can $f$ ind notable examples and underst and what is meant by length and strength of poetic flight. The invocation to Iight that opens Book III illustrates his masterly skill, in the binding of the poetic paragraph. "The harmonies of rhyme linked together into a perfect stanza could not create a whole more finished and more self-contained." Milton combined the two essential qualities of blank verse, - freedom and form; the freedom that admits variety of effect, without which a long narrative becomes intolerably monotonous, and the form which saves an unrhymed measure from drifting into that which is nearer to bad prose than to good verse. (2) By the use of his verse-stanzas, out of apparently uniform and monotonous blank verse, Milton made an instrument of almost Protean variety by "avajiing himself of the infinite permutations of cadence, syllabic sound, variety of feet, and adjustment of sense to verse". (3) His blank verse has all the conveniencesof the line, the couplet, and the stanza, punctuated and divided by cadence, not rhyme. No device that is possible within its limits is strange to him or sparingly used by him, or used. without success.

After Milton's death, blank verse dropped into obscurity; poets aroided its use. It has been said that Milton's influence upon his contempor aries and his immediate successors amounted

1. Crawshaw: Op. Cit., 176 .

2. Verity: P. I. Intro. IIX.

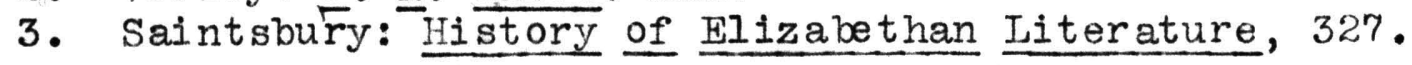



to practically nothing. He wrote for another age. The blank verse that was known to the poets of the seventeenth century was the blank verse of Suckling, Davenant, and others of Shakespeare's successors, who had carried to excess the freedom and Iicense found in Shakespeare's latest dramas. Blank verse, as they knew it, was poor prose; Milton's successors attempted to restrain the liberties verse was assuming, and, consequently, the years immediately following Milton's death witnessed the growth in $f$ avor and the excellence of the heroic couplet. By 1726, this form of verse had held the popular attention for over half a century, and had come to be regarded as the form for all serious poetry to take. This had attained such perfection at the hands of Pope that many of the younger school hesitated to at tempt its use. Partly from this reason, partly because there was a distinct Miltonic revival at this time, and partly because this was a period in his life when he was most under Milt on's influence, James Thomson broke away from the established form and published, in 1726, his Winter, written in blank verse.

This was a daring venture upon a form of verse which had only once before been $u$ sed in a great way for other than dramatic purposes, and which to the few, who up to this time knew Paradise Lost, had probably been considered sacred to the epical genius of Hilton. The only important writer who had employed blank verse in undramatic poetry between the publica- 

tion of Paradise Lost in 1672 and Thomson's Winter in 1726 , was John Philips. Quoting Milton's preface to Paradise Iost at a time when its author was in favor, added dignity and authority to $h$ is undertaking. Thomson recognized the wellnigh solitary character of Philips' poems when he alludes to him in Autumn,

Philips, Pomona's bard! The second thou Who nobly durst, in rime-unfettered verse, With British freedom sing the British song.

Yet Thomson did not hesitate. His admiration for Milton and his own genius compelled him to adopt this form of expression. The first draft of Thomson's Winter opened with all the explicitness and boldness of the old epic style.

I sing of winter and his gelid reign;

Nor let a rhyming insect of the Spring

Deem it a barren theme: to me itis full

of manly charms,- to me who court the shade,

Whom the gay Season suits not, and who shun

The glare of summer. Welcome, kindred glooms!

Drear, awful Wintry horrors, welcome all!

Yet Thomson's verse is not the blank verse of Milton. Nowhere has he attained Milton's height, ease, facility, harmony, and lack of monotony; nowhere has he attained that indefinable serenity, that victoriousness, that sustained equality, 

that indomitable power which characterises Milton's verse. Iine after line runs along without a break in the five-footed iambics; often there are long passages with only a very few feet to break the monotony.

But who their virtues can declare? who pierce

With $v$ ision pure into these secret stores

Of life, and health, and joy? the food of man

While yet he lived in innocence, and told

A length of golden years, unfleshed in blood,

A stranger to the savage arts of life,

Death, rapine, carnage, surfeit, and disease,

The Iord, and not the tyrant, of the world.

The first fresh dawn then waked the gladdened race

of uncorrupted man, nor blushed to see

The sluggard sleep beneath its sacred beam;

For their light slumbers gently fumed away,

And up they rose as vigorous as the sun,

Or to the culture of the willing glebe,

or to the cheerful tendance of the flock.

Spring, 234-248.

Fifteen successive lines with only one trochaic foot is not a masterly handing of blank verse. An examination of the one thousand one hundred seventy-four lines of Spring reveals few irregularities. There are no Alexandrine lines; there is no trace of trisyllabic feet; there are no weak endings; trochaic lines are in the minority. There is absolutely no roughness in any of these thousand lines wi th the possible exception of line 692. Thomson's lines have five full stresses; there are very few examples of inversion of rhythm. The Seasons unrolls itself with a rhythm remarkable for its regularity. Only the first foot is often anything other than an 

iambus. (1) Morel has recorded that of the one thousand sixty-nine verses of Winter there are only one hundred eighty, sixteen per cent, that begin with a trochee. (2)

Al] this is contrary to Milton's style. He has many supernumerary syllables; some of his lines have only three or four stresses; inversion of rhythm is very common in the first foot, often occurs in the third and fourth, rarely, but sometimes, in the second and fifth; (3) trisyllabic feet are frequent; there are many lines that it is impossible to scan according to our present rules with any degree of satisfaction. Yet, as Symonds has pointed out, his lines always have the "proper burden of sound". (4)

In the two respects, however, in which Milton's blank verse has been shown to be especially characteristic there is imitation on Thomson's part. His pauses vary; the sense is drawn from one verse into another. This is not done with the skill of Milton, but it is there. An examination of a number of lines bears out the Miltonic proportion, viz., the majority of the pauses coming after 3xa, with the pause after 2xa next in number. (5)

Thomson's attempt at Milton's "grand style" and his attempt to sustain harmony and rhythm through a number of lines is

1. Morel; Op. Cit., 468.

2. Morel: Op. $\overline{\mathrm{C} i t} ., 469$.

3. Bridges: Milton's Prosody, 1-17.

4. The Blank Verse of Milton, 772 .

5. Cf., Corsonts table, Primer of English Verse, 194. Morel has found in the first three hundred verses of Summer, ninety-five pauses after the second foot, seventy-two 

very manifest. The result is partial failure--sometimes a ludicrous one. He moves through a vast variety of scenes with a lofty sedateness, a serene moral dignity, a conscious sublimity, "a grand style" that falls flat when the subject is fishing, an address to the Countess of Hertford or the plow, a category of plants or animals, a plea for vegetarianism, an address to sheep about to be sheared, an appeal to women not, to hunt, and more or less commonplace matters. Such words as embryo, vegetable, granary, sidelong, mildew, corrosive, incult, botany, botanist, reservoir, innoxious, concoctive, sequacious, portentous, emergent, pestilential, detruded, etc., are good words, but they scarcely add dignity to an epic line. Milton's grand style is eminently suited to his grand theme; blank verse may be fitted to some of Thomson's subjects, - there are instances of true poetical worth in his poetry. However that may be, one hears on page after page in flowing and sonorous lines a suggestion and imitation of the statelier and more sustained music of Paradise Lost.

The following passage, a verse-stanza of only six sentences, su ggests Milton, not in conception and language (though there are instances of slight imitation) but in form. One feels, rather than sees, the Miltonic influence as he reads aloud such a passage as this:

after the third, and twenty-one after the first. ( p.470) An examination of the whole of Spring and of other parts of The Seasons evidences the caesurafalling in the Miltonic proportions. 

From the moist meadow to the withered hill,

Ised by the breeze, the vivid verdure runs,

And swells, and deepens to the cherished eye.

The hawthorn whitens; and the juicy groves

Put forth their buds, unfolding by degrees, Till the whole leafy forest stands displayed

In full luxuriance to the sighing gales;

Where the deer rustle through the twining brake, And the birds sing concealed. At once, arrayed

In all the colours of the flushing year

By Nature's swift and secret-working hand,

The garden glows, and fills the liberal air

With lavish fragrance; while the promised fruit

Lies yet a little embryo, unperceived,

Within its crimson folds. Now from the town

Buried in smoke, and sleep, and noisome damps,

Oft let me wander o'er the dewy fields

Where freshness breathes, and dash the trembling drops

From the bent bush, as through the verdant maze

Of sweet-briar hedges I pursue my walk;

Or taste the smell of dairy; or ascend

Some eminence, Augusta, in thy plains,

And see the country far diffused around

One boundless blush, one white-empurpled shower

of mingled blossoms, where the raptured eye

Hurries from joy to joy, and, hid beneath

The fair profusion, yellow Autumn spies -

If, brushed from Russian wilds, a cutting gale

Rise not, and scatter from his humid wings

The clammy mildew; or, dryjolowing, breathe

Untimely frost, before whose baleful blast

The full-blown Spring through all her foliage shrinks,

Joyless and dead, a wide-dejected waste.

For oft, engendered by the hazy north,

Myriads on myriads, insect armies warp

Keen in the poisoned breeze; and wasteful eat

Through buds and bark into the blackened core

Their eager way. A feeble race, yet oft

The sacred sons of vengeance; on whose course

Corrosive famine waits, and kills the year.

To check this plague, the skillful farmer chaff

And blazing straw before his orchard burns,

Till, all involived in smoke, the latent foe

From every cranny suffocated falls;

Or scatters o'er the blooms the pungent dust

Of pepper, fatal to the frosty tribe;

Or, when the envenomed leaf begins to curl,

With sp ringled water drowns them in their nest;

Nor, while they pick them up with busy bill,

The little trooping birds unwisely scares.

Spring, 85-135. 

Milton writes of nature in one place thus,

Sweet is the breath of Morn, her rising sweet, With charm of earliest birds; pleasant the Sun, When first on this delightful land he spreads His orient beams, on herb, tree, fruit, and flower, Glistering with dew; fragrant the fertile Earth After soft showers; and sweet the coming-on Of grateful Evening mild; then silent Night, With this her solemn bird, and this fair Moon, And the se the gems of Heaven, her starry train;

P.. . IV, $641-649$.

Thomson shows his indebtedness to Milton when he writes,

Shopt is the double empire of the night;

And soon, observant of approaching day,

The meek-eyed morn appears, mother of dews,

At first faint-gie aming in the dappled east;

Till far o'er ether spreads the widening glow,

And from before the lustre of her face

White break the clouds away. With quickened step

Brown night retires. Young day pours in apace,

And opens all the lawny prospect wide.

The dripping rock, the mountains misty top

Swell on the sight, and brighten with the dawn.

Blue through the dusk the smoking currents shine;

And from the bladed field the fearful hare

Iimps awkward; while along the forest glade

The wild deer trip, and often turning gaze

At early passenger. Music awakes,

The native voice of undissembled joy;

And thick around the woodland hymns arise.

Roused by the cock, the soon-clad shepherd leaves

His mossy cottage, where with peace he dwells;

And from the crowded fold in order drives

His flock to taste the verdure of the morn.

Sumner, $46-66$. 

A comparison of the se two passages shows the influence of Milton's blank verse upon that of Thomson;

Hail, holy Light, offsp ring. of He aven first-born! Or of the Eternal coeternal beam May I express thee unblamed? Since God is light, And never but in unapproached light

Dwelt from eternity - dwelt then in thee, Bright effluence of bright essence in create! Or hear'st thou rather pure Ethereal stream, Whose fountain who shall tell? Before the Sun, Before the Heavens, thou wert, and at the voice Of God, as with a mantle, didst invest The rising World of waters dark and deep, Won from the void and formless Infinite!'

Welcome, ye shades! ye bowery thickets, hail!

Ye lofty pines! ye venerable oaks!

Ye ashes wild, resounding o'er the steep!

Dellcious is your shelter to the soul, As to the hunted hart the sallying spring

or stream full-flowing, that his swelling sides

Laves as he floats along the herbaged brink.

$$
\text { Summer, } 469-475 \text {. }
$$

The passages that follow are surely Miltonic in their form and in the onward sweep of the verse:

Then to the shelter of the hut he fled And the wild season, sordid, pined away; For home he had not: home is the resort Of love, of joy, of peace and plenty, where, Supporting and supported, polished friends And dear relations mingle into bliss. But this the rugged savage never felt, Fiven desolate in crowds; and thus his days Rolled heavy, dark, and unenjoyed along, A waste of time! till Industry approached And roused him from his miserable sloth, His faculties unfolded, pointed out 

Where lavish Nature the directing hand Of art demanded, showed him how to raise His feeble force by the mechanic powers, To dig the mineral from the vaulted earth, On what to turn the piercing rage of fire, On what the torrent and the gathered blast; Gave the tall ancient forest to his axe, Taught him to chip the wood and hew the stone Till by degress the finished fabric rose; Tore from his limbs the blood-polluted fur And wrapt them in the woolly vestment warm, or bright in glossy silk and flowing lawn; With wholesome viands filled his table, poured The generous glass around - inspired to wake The life-refining soul of decent wit; Nor stopped at barren bare necessity, But, still advancing bolder, led him on To pomp, to pleasure, elegance and grace; And, breathing high ambition through his soul, Set science, wisdom, glory, in his view, And bade him be the lord of all below.

Autumn, 63-95.

But wondering oft with brute unconscious gaze Man marks Thee not, - marks not the mighty hand That ever-busy wheels the silent spheres, Works in the secret deep, shoots steaming thence The fair profusion that o'er spreads the spring, Flings from the sun direct the flaming day, Feeds every creature, whirls the tempest forth, And, as on earth this grateful change revolves, With transport touches all the springs of life.

Hymn, $28-36$.

Milton's superiority is evident. Every page affords a verse-paragraph which might well illustrate the incomparable elevation of the style, the shaping spirit of the imagination, the mere majesty of music, qualities that in the opinion of 

some critics have made Paradise Lost Iive. (I) That Thomson rivalled or even approached Milton in the sublimity of his blank verse cannot be established. Milton's exquisite rhythm was never caught by Thomson. He could copy Milton's form, but he could not render the charm of his lines; he did not have the mastery of the technique of blank verse that Milton had; he did not have Milton's finely attuned ear; he did not choose a subject comparable to Milton's; his blank verse is not Miltonic. One feels that when Thomson reached the end of his verse-paragraph it was with a sigh of relief and a burst of exultation over his finished product. Thomson is a verse-smith; he works awkwardly and clumsily. His paragraphs are not linked the one to the other with the consummate art Milton displayed. Yet to say that Thomson would have written the blank verse he did without his predecessor, that he was uninfluenced by Paradise Lost, that his invocations, his verse-paragraphs, his dignified sonorous sentences are his own creation would be to make a statement that even the Iimited passages cited above refute. And Gosse is surely right when he says that The Seasons recall to English verse a melody, a rapture which had been entirely unknown since Milton's death sixty years before. (2) Thomson's indebtedness to MiIton is most apparent in The Seasons, particularly in the closing

1. Verity: Op. Cit., IIII; Saintsbury: Op. Cit., 328.

2. op. Cit., 236 . 

Hymn, but traces of the "grand style" apear in his shorter poems, especially in To the Memory of Sir Isaac Newton and The Fragment of a Poem on the Works and Wonders of Almighty Power. Thomson has also employed some of the subleties of style which Milton has displayed in his blank verse. The charm of much of Paradise Lost depends in no small part upon alliteration. Milton's alliteration is not the strident sort that forces itself, upon the ear, but rather flatters by delicate suggestion and subtle echoes of recurring sound. For instance, there is an $\underline{f}$ and $\underline{I}$ sequence in the following:

Fairer than feigned of old, or fabled since

Of faery damsels, met in forests wide

By knights of togres, or of Lyones, Lancelot, or Pelleas, or Pellenore.

$$
\text { P. R. II, - 358-36I. }
$$

and this,

Far off from these, a slow and silent stream, Lethe, the river of oblivion, rolls

Her watery labyrinth, whereof who drinks Forthwith $h$ is former state and being forgets Forgets both joy and grief, pleasure and pain.

$$
\text { P. I. II, 582-586. }
$$

Thomson is particularly fond of this sequence, and appears to imitate it from Milton.

To the fair forms of Fancy's fleeting train. Surmer, 928 . 

From stifled Cairo's filth, and fetid fields

Summer, 1056.

And in loose fragments fling them floating round.

Winter, 174 .

At first thin-wavering; till at last the flakes

Fall broad and wi de and fast, dimming the day

With a continuous flow. The cherished fields

Winter, 230-232.

It is $r$ are to find a structure of repeated $\mathbf{s}$ in Milton, but in Paradise Lost V, $322 \mathrm{ff} .$, is found,

- - - - - small store will serve where store,

All seasons, ripe for use hangs on the stalk;

Save what, by frugal storing, firmness gains

To nourish, and superfluous moist consumes.

Thomson has,

Sound slept the waters; no sulphureous glooms

Swelled in the sky, and sent the lightning forth;

Spring, 326-327.

The descriptive pomp of the alliterative system is remarkable In the passage where Raphael relates the division of earth from water. 

Immediately the mountains huge appear

Fmergent, and their broad bare backs upheave

Into the clouds; their tops ascend the sky.

So high as heaved the tumid hills, so low

Down sunk a hollow bottom broad and deep,

Capacious bed of waters. Thither they

Hasted with glad precipitance, uprolled,

As drops on dust conglobing, from the dry:

Part rise in crystal wall, or ridge direct,

For haste; such flight the great command impressed

On the swift floods. As armies at the call

Of trumpet (for of armies thou hast heard)

Troop to their standard, so the watery throng,

Wave rolling after wave, where way they found -

If. steep, with torrent rapture, if through plain,

Soft-ebbing; nor withstood them rock or hill;

But they, or underground, or circuit wide

With serpent error wandering, found their way,

And on the washy ooze deep channels wore:

P. I. VII, 285-303.

Symonds has pointed out how, here the $\underline{b}$ and $\underline{h}$, not inaptly mark the firmness and resistance of the earth, while $\underline{w}$ and $\underline{V}$ depict.the liquid lapse of waters.

Thomson has attempted to attain the same charm in Autumn

by the use of the liquids.

Shook sudden from the bosom of the sky

A thousand shapes or glide athwart the dusk

Or stalk majestic on. Deep-roused I feel

A sacred terror, a severe delight,

Creep through my mortal frame; and thus, methinks,

A voice, than human more, the abstracted ear

Of fancy strikes: 'Be not of us afraid,

Poor kindred man! thy fellow-creatures we

From the same Parent-Power our beings drew;

The same our Iord, and laws, and great pursuit.

Once some of us, like thee, through stormy life

Toiled tempest-beaten ere we could attain 

This holy calm, this harmony of mind, Where purity and peace immingle charms.

$538-549$

The majority of Thomson's minor poems are written in ordinary rhyming heroics. While four of Milton's minor poems are written in this metre, the prevailing style of Thomson's age and the lack of any Miltonic characteristics. In his verse make any positive statement in this respect impossible. To Seraphina and A Nuptial Song, octosyllabic iambics, bear some resemblance to Milton's I'Allegro and II Penseroso. Especially in the latter, there is a Miltonic echo and swing. It is primarily in his blank verse, however, that Thomson is indebted in form to Milton.

Just as the Romantic school was inore influenced in conception by Milton's minor poems than by his epic, so the form of II Penseroso and I'Allegro affected the poetry of Collins and dray more than did Paradise Lost. Collins has left us nothing in blank verse; Gray has only a fragment of a drama in that measure. Why they were not influenced by Milton's blank verse is an interesting problem. Both Gray and Collins have for the most part written odes, and their inspiration for this form naturally came from the classics. Neither of them has attempted a poem on a theme to which blank verse would be well adapted. Gray had too keen a sense of poetical fitnesis and beauty and harmony to attempt to fit the grand style of 

Milton to a mean theme. His musical ear could never have permitted anything like some of the passages in The Seasons. It is a possibility, too, that Thomson's attempt was sufficient warning; after his partial failure, they did not care to venture upon blank verse. They were likely familiar with it for Collins and Thomson were friends in the latter part of Thomson's life; Collins undoubtedly knew Thomson's works. Since Gray was an omniverous reader and an habitual student, both of the ancient and contemporary literatures, it may safely be inferred that he had read The Seasons. Perchance, then, Thomson's Seasons made Gray and Collins more keenly realize that Milton's blank verse is suited only to grand themes. Although Gray did not imit ate Paradise I,ost in form, it is said that he could endure no blank verse outside of Milton, (I) and in his Elegy (Iine 59) he refers to Milton as the great type of poets.

Although they were not influenced by Milton's blank verse, there are a few bits of evidence that point to their indebtedness to him in other forms. Gray knew his Milton and appreciated the master's verse as is shown by his eulogy in his Observations on English Metre in which he says, "The more we attend to the composition of Milton's harmony, the more we shall be sensible how he loved to vary his pauses, his measures and his feet, which gives that enchanting air of

1. Beers: 0 p. Cit., 52 . 

freedom and wildness to his versification, unconfined by any rules but those which his own feeling and the nature of his subject demands." (I) In no less than four places in the small body of his poems Gray has rendered praise and eulogy to Milton's form.

Nor second He, that rode sublime Upon the seraph-wings of Extasy, The secrets of th' Abys to spy.

He pass'd the flaming bounds of Place and Time:

The living Throne, the saphire-blaze, Where Angels tremble, while they gaze, He saw; but blasted with excess of light, Closed his eyes in endless night.

Prog. Poes. 95-102.

'Twas Milton struck the deep-toned shell, And, as the choral warblings round him swell, Meek Newton's self bends from his st ate sublime, And nods his hoary head, and listens to the rhyme. music, 23-25.

A Voice, as of the Cherub-Choir, Gales from bloomine Eden bear;

Bard, 131-132.

But not to one in this benighted age

Is that diviner inspiration given,

That burns in Shake speare's or in Milton's page,

The pomp and prodigality of heaven.

Stanzas to Mr. Bentley, 17-20.

1. Quoted in Phelps: Op. Cit., 166. 

There are also examples of direct borrowing of form. In his Epitaph on Mrs. Clarke, there is evidence of the influence of Milton's Epltaph on the Marchioness of Winchester in both form and conception. Compare the opening couplet of e ach:

This rich marble doth inter

The honoured wife of winchester,

Lo! where this silent marble weeps, A Friend, a Wife, a Mother sleeps;

The Descent of Odin and The Triumphs of Owen have the metre of $\mathrm{I}^{\prime A l l e g r o}$ and II Penseroso. The influence of Milton. style comes out clearly in such a passage as

\footnotetext{
Right against the eastern gate, By the moss-grown pile he sate; Where long of yore to sleep was laid The dust of the prophetic Maid. Facing to the northern clime, Thrice he traced the runic rhyme; Thrice pronounc'd in accents dread, The thrilling verse that wakes the Dead; Till from out the hollow ground Slowly breath'd a sullen sound.
}

Des. Odin, 17-26.

Such lines as

With antique Sports, and blue-eyed Ple asures,

1. Prog. Poes., 30 

have the I'Allegro and II Penseroso swing.

Finally, in his Ode for Music, Gray has one stanza that is not only full of Miltonic phrases but is written in the metre of the Nativity Ode.

Ye brown o'er-arching Groves,

That Contemplation loves,

Where willowy Camus lingers with delight!

Oft at the blush of dawn

I'trod your level lawn,

Oft woo'd the gleam of Cynthia silver-bright

In cloisters dim, far from the haunts of Folly,

With Freedom by my Side, and soft-ey'd Melancholy.

Music, 27-34.

Collins' debt to Milton is also openly made in several places. He prefixes a quotation from one of Milton's Latin poems to his On Our Late Taste in Music, and in the same paem (line $29 \mathrm{ff.}$ ) he shows his appreciation of comus:

So while she varies the impassion'd song, Alternate motions on the bosom throng!

As heavenly Milton guides her magic voice, And virtue thus convey'd allures the choice.

Collins' Ode to Evening, considered the most beautiful and most original of his odes, is composed in the Horation unrhymed metre. It is a very difficult verse-form and has seldom been used with success in English. The earliest specimen of this unrhymed ode form in Finglish is Milton's trans- 

lation of the Fifth Ode of Horace, Book I. John Warton's poems, published at the same time as Collins', contain also an unrhymed ode to Content. That both of these forms were at tempted on account of their early study of the classics and of Milton's translation seems probable.

In his Ode on the Poetical Character, Collins openly acknowledges his attempt to follow Milton's verse-forms.

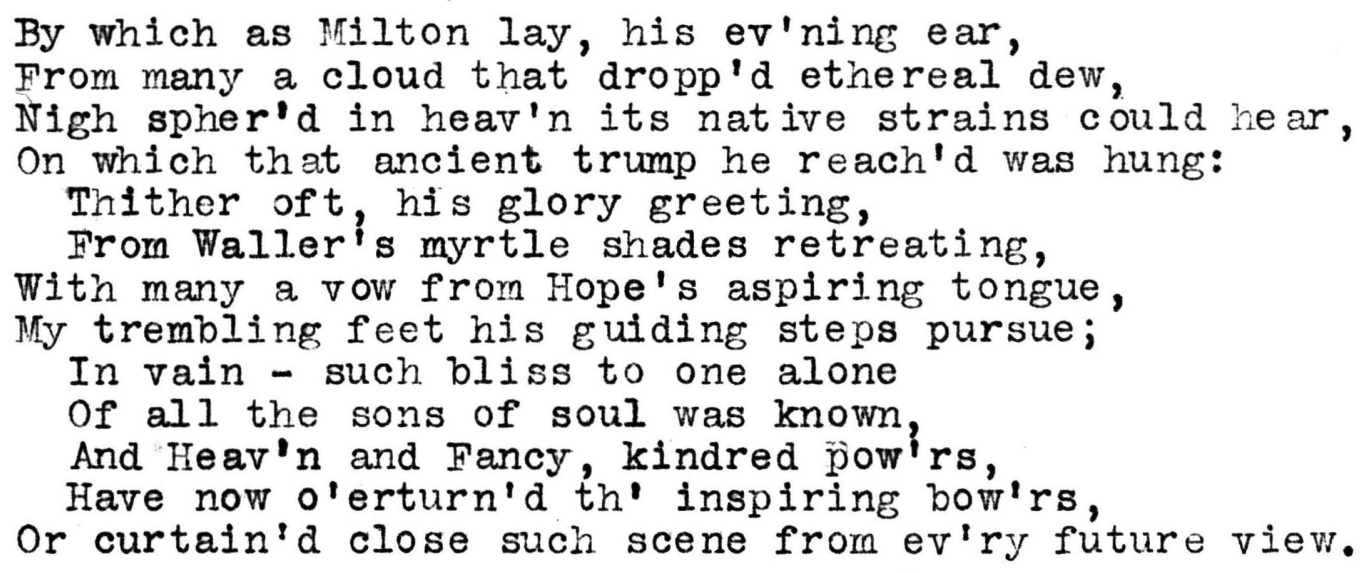

$$
63-76 \text {. }
$$

Collins wrote one poem in which his trembling feet did pursue Mliton's guiding steps. The Ode to Simplicity is written in the same metre whol Milton employed in his Nativity Ode. Collins and Gray, realizing the artistic effectiveness of closing a stanza with an Alexandrine line, have employed it in several of the stanzas of their odes. (2) Milton fur-

I. For Milton's translation, cf., Masson: Op. Cit., I, 441. 2. Gray: Hymn to Adversity, The Progress of Po esy, The Bard, Ode for Music; Collins: Ode on the Poetical Character, ode to Mercy, ode to Iiberty, ode on the Popular superstitions. 

nished a model here. He has used Alexandrine lines in Comus and Paradise Lost to round off his verse-stanzas, and has employed them very effectively in two of his juvenile poems. It is very probable, however, that Milton and the Romanticists have a common master in this respect - Spenser.

It is perhaps worthy of note that Spenser, who had great influence upon many of the Romanticists in conceptions and language, influenced Collins and Gray very little. Mason and Thomas Warton each have one poem written in the Spenserian stanza. Gray and Collins show very little, if any, evidence of Spenserian influence in form or conception. Thomson in his Castle of Indolence is the scholar who caught the glow of Spenser's form best. It is of interest for the study of his indebtedness to Hilton to note that this was the last poem of Thomson's, (it appeared only two months before his death), and that the reference to spenser in summer did not appear in tine first edition, but was inserted later. From a letter of Thomson's written in 1748 we know that he had such a poem as The Castle of Indolence in mind for fourteen or fifteen years. It is impossible to say how intensive his study of spenser was during this time.

Morel attributes Thomson's study of Spenser to his later years and thinks he chose the Spensersian stanza for The Castle of Indolence because he realized that the verse of Paradise

1. For authority cf., Phelps: Op. Cit., 74. 

Lost was too grave for such a subject, that his old age and experience had diminished his fervor for such a solemn strain, and that his liter ary taste had changed somewhat. (1) Further evidence that Thomson was under Milton's influence in his early life may be deduced from the fact that his juvenile poems written before The Seasons include a paraphrase of Psalm CIV, A Pastoral upon the Birth of Our Saviour, a short poem, entitled On May, which were probably suggested by Milton's early parphrases of the Psalms, his Nativity Ode, and his Song on May Morning. In form these are in the heroic couplet, but there are also at tempts at blank verse in his early poems. $\mathrm{He}$ also wrote a preface to Milton's Areopagitica, published by Millar in 1638, and there are several internal references to Milton. (3) These facts would seem to contradict Professor Beers' statement that Thomson took his "form and hue" frorn Spenser. (4) He was influenced by him, but it seems clear that he was influenced no less strongly by Milton.

The majority of Thomson's lines are written in blank verse. He was the first poet of importance after MiIton to at tempt this form in English poetry. Thomson's use of pauses, of the verse-paragraph, of several minor subtleties of style, his

1. Op. Cit. , 635 .

2. Iisy's Parting with her Cat, To the Memory of Sir Isaac

3. Cf., Summer, 1567-1571; 年inter, $\frac{\text { Newton }}{33-536}$.

4. Beers: Op. Cit., 92. 

sonorous sentences and attempted flights of sublimity seem to have been imitated directly from Milton. Gray and collins have left little proof of the influence upon them of Milton's blank verse, but they admired it thoroughly. They have rendered homage to his minor poems; Gray has eulogized Milton's form in his poems and has borrowed it in at least three instances; Collins has al so made internal reference to his admiration for Milton's verse and has written two poems in his metres. These facts seem to justify the statement that Milton influenced Thomson, Gray, and Collins in form. 

PART VI.

\section{MINOR INFLUENCES OF MILTON}

There are some minor points that may tend to establish the claim that Thomson, Gray, and Collins were under Milton's influence.

\section{Personified Abstractions.}

The allegorical pictures in L'Allegro and II Penseroso gave rise to the "feeble mythology" of the eighteenth century. The personfication in the se two poems of Imps, Cranks, Wiles, Nods, Becks, Smiles, Mirth, Melancholy, Darkness, Sleep, Joy, Folly, Peace, Quiet, Fast, Leisure, Contemplation and

Sport that wrinkled Care derides, And Iamghter holding both his sides

furnished an excuse to the Miltonic revivalists for the personification of every abstract conception. Thomson has done this to excess in Liberty and The Seasons; the first twentyfive lines of The Seasons have twenty personified abstractions. He is by no means free of it in The castle of Indolence. Gray has personified ninety-seven abstract conceptions; Collins has seventy-one. Everything from Wonder, Wit, Remembrance, Re- 

bellion, Plenty, Opinion, Observance, Murder, Meekness, Madness, Disease, Fxercise, Echo, Dullness, Doubt, Distress, Danger, Conquest to our more frequently personified ideas of Mirth, Joy, Mercy, Truth, Virtue, Slavery, War, Youth, Age, Pleasure, Music, Sympathy, Ambition, Anger, Anguish, Care, Charity, Death, etc., etc., are dignified with capital letters and talked about as if they were persons. In Gray's Ode to Adversity, there are in about fifty lines personifications of Adversity, Virtue, Folly, Noise, Joy, Prosperity, Melancholy, Charity, Justice, Pity, Horror, Despair, Disease, and Poverty. Collins' Ode to the Passions is a very fine example of the same tendency. Professor Raleigh has pointed out that Milton's management of personification is superb. It is a figure difficult to handle and generally fails of effect through failing into one of two extremes; either the quality or the person is forgotten. (I) The Romanticists have not handled the figure superbly. They have fallen at times into both of these faults. But the fact remains that they seem to have been encouraged in the $u$ se of the personified abstraction by Milton's use of it.

II. Avoidance of Plain Concrete Terms.

Milton's starting-point was ordinarily an abstraction; each real person tends to become the representation of an idea 

or a group of ideas; and it was necessary for him in describing a world unknown and unseen to use shadowy abstract language and to avoid the $u$ se of plain concrete terms. He refers to spring flowers as "vernal bloom" (Paradise Lost, III, 43), to the rainbow as "the humid bow" (… I. IV, 151 and Com. 992), to gunpowder as "nitrous powder" (… I. IV, 815) or "smutty grain" (ㅁ․ I. IV, 8I7), to the telescope as "optic tube" (‥ I. III, 590), to cannon balls as "iron globes" (‥ I. VI, 590) and "balls of missive ruin" (ㅁ․ I. VI, 519), to the linstock as "the incentive reed pernicious" (․․ I. VI, 520), to the brooks rolling as "with mazy error under pendant shades" (‥ I. IV, 239), to the sun receiving from earth "his alimental recompense In humid exhalations" (․․ $\underline{I} . V, 424-425$ ), to food as "corporal nourishments" (… I. V, 496). Such phrases and Iines as "The palpable obscure" (…… II, 406) and "Sonorous metal blowing martial sounds" (‥ $I . I, 540)$ are numerous. The eighteenth century abused this habit of style; it became a vicious trick in the hands of its poets. As professor Raleigh has pointed out "A reader making his first acquaintance with Thomson's Seasons might suppose the poem was written for a wager, to prove that country life may be described, and nothing called by its name. - . - When he speaks, for instance of the 'feathered nations' or of 'the glossy kind' it is only by the context that we are saved from supposing him to 

allude, in the one case to Red Indians, in the other to moles". (1) There are dozens of instances that support this statement of Professor Raleigh's; a few might be indicated. Chimneys are called "smoking currents" ( of the morn" ( Sum. 66), the sun, "the powerful king of day" (Sum. 81 ) and "informer of the planetary train" (Sum. 104), the stars, "the lamps of heaven" (um. 180), twilight, "the falling glooms" (Sum. 197), the sunflower, "the lofty follower of the sun" (Sum. 216), a cow, "the full-uddered mother" (Sum. 222), flies, "the noisy summer race" (Sum. 237),"the ox's hay, the fruit of all his toil" (Win. 242), the winter forest,"the foodless wilds" (Win. 256), sheep, "the bleating kind" (Win. 261), rain, "condensed.vapours" (Aut. 1085), bees, "the stillheaving hive" (Aut. 1173) and "the tender race" (Aut. 1181), a brook, "the mossy-tinctured stream" (Spring, 380), fish, "the finny race" (Spring, 394) and "crimson-spotted fry" (Cast. Ind. I, 159), coffee, "the sage berry sun-burnt Mocha bears" (Cast. Ind. I, 268), the interior of the earth, "beneath earth's verdant floor" (Cast. Ind. II, 93), and the contest between a fly and a spider is described thus;

But chief to heedless flies the window proves A constant death; where gloomily retired The villian spider lives, cunning and fierce, Mixturemabhorred! Amld a mangled heap 

Of carcases in eager watch he sits,

o'erlooking all his waving snares around.

Near the dire cell the dreadless wanderer oft

Passes: as oft the ruffian shows his front.

The prey at last ensnared, he dreadful darts

With rapid glide along the leaning line,

And, fixing in the wretch his cruel fangs,

Strikes backward, grimly pleased: the fluttering wing

And shriller sound declare extreme distress,

And ask the helping hospitable hand.

Sum. $267-280$

Gray is also guilty in this respect. In his ode on the Spring, he refers to the nightingale as "The Attic warbler", to cattle as "the panting herds", to insects and reptiles as "they that creep, and they that fly", to optimists as "the sportive kind", to bees and their humming as

Yet hark, how thro' the peopled air

The busy murmur glows!

In another ode, instead of the yellow cornfields, we have "Ceres" golden rain"; in his sonnet, the sun does not rise, but "redning Phoebus lifts his golden Fire"; the birds do not sing, but "their amorous Descant joyn"; the fields "resume their green Attire"; "morning smiles the busy Race to chear"; and the fields bear their "wonted Tribute". 

Collins is more free from this use of abstract terms than Thomson and Gray, but instances of this style may be found in his Ode to Simplicity, Ode on the Death of Mr. Thomson, and, occasionally, in his other poems.

(I)

\section{Compound Words.}

Milton's use of compound words is so conspicuous as to have called forth much comment and appreciation. They are always felicitous, suggestive, and frequently beautiful. Archbishop trent has called them "poems in miniature". Thomson, Collins, and Gray have followed Milton's style in this respect also. Sometimes, they have borrowed Milton's own compounds, as Thomson and Gray in rosy-bosomed, Gray in dove-like, and Collins in white-robed, low-roofed, love-darting, and allcommanding; but in many cases, following the genius of Milton, they have created their. own compound epithets. Some of theirs, too, are miniature poems; Thomson, especially, has excelled in this particular.

The majority of Thomson's compound words are composed of substances, as the harvest-treasure, tulip-race, torrent-softness. Of his epithets, the first term is frequentiy a noun followed by an adjective, as blood-happy, plume-dark, but more often the second term is a past-participle: sage-instructed eye, flower-enwovèn bowers, rhyme-unfettered verse, etc. Some 

of his compounds are formed with adverbs; ever-dripping fogs, well-dissembled fly. One of his most frequent is that which affects the form of the past participle, as, rosy-footed May, young-eyed health, dewy-skirted clouds. In all the se instances Milton has been his model, both in formation and use. (1)

IV. Long-tailed Similes.

Most of the passages that have gained for Milt on the name of a learned poet are introduced by way of simile. At times he employs the simplest epic figure, drawn from the habits of rustic or animal life. "But his favorite figure is the longtailed simile, or, as it is often called, the decorative comparison, used for its ennobling rather than for its elucidating value".

Once more, Milton is found serving as a prototype for the Romanticists. Gray and Collins had very little opportunity to use the long-tailed simile in their odes; (3) but Thomson has employed it very effectively. It should be observed that

1. Collins has 52 compound words; Gray, 80; Thomson, 538, 358 of which are found in the Cast. Ind. and The Seasons, 120 in Liberty, and 60 in the minor poems.

2. Op. Cit., 98. (Raleigh)

3. Gray empioys two long-tailed similes in his opening lines of Educ. and Gov. 

both Homer and Virgil have used this figure; yet inasmuch as Thomson seems to have borrowed from the English epic in other details, it may be assumed that he is in debt to Milton in this instance.

V. Iatin Names and Epithets.

Educated at one of the two most celebrated seats of learning in Fngland, and endowed by nature with talents of the highest order, Milton became a Latinist, Hellenist, Hebraist, master of Italian, and like all great scholars, was endowed in a very high degree with the faculty of reproducing at will the results of his wide reading. As a consequence, paradise Lost is perhaps the most learned poem in the English language. The poets of the eighteenth century were attracted to this store of learning. The Romanticists could not resist the attractions of Milton's Latin voc abulary. Where Milton describes how, in Paradise -

$$
\text { the flowery lap }
$$

of some irriguous valley spread her store;

Thomson follows with -

See where the winding vale its lavish stores Irriguous spreads.

1. Milton's use of the long-tailed simile mav be illustrated by Paradise Lost IV, $159 \mathrm{ff} ., 183 \mathrm{ff} .$, I, $338 \mathrm{ff.,} 594 \mathrm{ff.;}$ II, 487ff., 636ff.; III, 543ff.; IX, $445 \mathrm{ff}$. For illustration in Thomson of., Spring $69 \mathrm{ff.;}$ Cast. Ind. I, 177ff., 262ff., 370ff., 568ff.; II, 568ff., 570ff., 577ff., 720ff.; Lib. III, $320 f$.

2. Gurteen: The Egic of the Fall of Man, 133. 

Sat an, according to Milton,

- - - - writhed him to and fro convolved,

Thomson describes how

The sportive lambs

This way and that convolved.

Thomson seems to object to calling spring flowers anything but vernal flowers, snows are dissolving snows, the atmosphere is expansive, the soul is vivifying, the master leans incumbent, man is laborious, the domain of the sea is turbulent, the air is lenient, the earth is verdant, rivers and gales are humid, the south wind is effusive, the floods are diffusive; the leaves are umbrageous; pungent, crude, observant, inflated, bounteous, amorous, etc., appear again and again.

Gray in the Iine,

The Birds in vain their amorous Descant joyn;

has Milton's Latin words,

She all night long her amorous descant sung. He addresses Adversity,

Whose iron scourge and tort'ring hour, The Bad affright, afllict the Best!

and has Milton's Latin epithet, that says

- - - - - - -the scourge

Inexorably, and the torturing hour

Calls us to penance.

VI. Peculiarities of Style.

Thomson seems to have imitated Milton in several minor 

respects of style. Milton is fond of using a nominative absolute; me overthrown, us dispossessed, him destroyed. Thomson has many of them. It is a construction that he seeks. $\overline{-}-\overline{-}-\overline{-}$ - He now shut up Within his iron cave.

Dashed down and scattered by the tearing wind's Assiduous fury its gigantic limbs.

At last, extinct each social feeling.

Milton very often inverts his adjectives and nouns, verbs and adverbs, etc. The very first lines of Paradise Lost illustrate this. Such lines as

A dungeon horrible, on all sides round,

The infernal Serpent: he it was whose guile

are frequent. Thomson follows with such expressions as - - - - if some sharp rock or shoal insiduous

- - - - - - the brawling brook And cave presageful (Z).

Milton often places an adjective on either side of the noun, as, sad occasion dear, towered structure high, that old man eloquent. Thomson follows with joyless rains obscure, the pillared dome magnific, in endless mazes intricate. Gray has al so noted and borrowed this mannerism in his Elegy, Full many a gem of purest ray serene.

1. For further illustration cf., Spring, 751, Sum. 348-351, Aut. 245-246, 856-860, Win. 968 etc.

2. Cf. also Aut., 407, $408, \frac{1}{433}$, win. 127, 693, 694. 

VII. Treatment of Nature.

Critics have maintained that Milton's knowledge of nature was a second-hand knowledge. Squires has gone to some length in considering Milton's treatment of nature. After cataloguing and classifying the references to birds, animals, and aspect of nature, he concludes that Milton betrays no intimacy with nature, that his knowledge of birds and animals is slight, that most of the animals named by him are foreign and ar e not known to him from direct observation, and that "his idea of beauty seems to have been not a natural landscape but a garden, not the real features of a simple English scene, but an impossible Arcady or Arden forest."

On the other hand, Walter Savage Iandor claims that "if ever there was a poet who knew her well, and described her in all her loveliness it was Milton." (2) Shairp maintains that the "pure breath of the country and the fragrance of the fields " (3) is to be found in Milton's poems. Morel attributes to Milton a firm grasp of reality, a large and profound feeling for nature.

It is true that Milton's most vivid renderings of scenery are found in L'Allegro, II Penseroso, Lycidas, and Comus. These poems were probably written during the five years of country life which he passed at Horton just after leaving

1. Milton's Treatment of Nature, 474.

2. Quoted in The Journal of Germanic Philology, II, 245.

3. Poetic Interpretation of Nature, 192.

4. Op. Cit. 230 . 

'Cambridge. Although he was primarily engaged in the study of Greek and Lat in, hi.s heart was perhaps more open to the beauty of rural nature than at any other time of his life. When Paradise Lost was written he was blind, and his subject did not present an opportunity for a minute treatment of nature. Squires' statistics are based upon his later poems as well as his earlier. Were his minor poems treated alone, the mathematical results would be quite to the contrary in many respects. Comus and Iycidas contain fine natural imagery. Throughout Iycidas, mingled with its imitative artificiality, are outbursts of real appreciation of nature herself undraped in any mythologic disguises. (1) In his I'Allegro and II Penseroso are found the clearest proofs of an observance of nature at first hand. She appears in these poems without any bookish allusions, with the outlines clear and distinct, and clothed in language the most graceful and musical. His description of the early morning is true and natural. The "russet lawns, and fallows gray", the cottage chimney smoking betwixt two aged oaks, "the tann'd haycock in the mead", the moon

- - - -as if her head she bowed,

stooping through a fleecy cloud - . - . -

the shower pattering

- - - -on the rustling leaves

With minute-drops from off the eaves, - - - these are all pictures taken at first hand from English land1. Cf., Iines 28, 136-138, 142-150, 190 . 

scapes. There is evidence that as a man of middle-age, Milton loved nature. (I) Once in Paradise Lost, Milton returns to the simple love of nature, (2) but his immense scholarship, experiences in political life, contemplation of humanity and divinity, with other causes previously mentioned, seem to have excluded for the most part his early love of nature. On the whole, he seems to have known and loved nature, but he was firşt of all a student, a man of letters, and nature was never an end in itself, but only a means to an end.

After Milton's death, rural life and nature disappeared from English poetry for more than half a century. (3) The artificiality of the eighteenth century was evident also in this respect. Men seemed content to regulate their thoughts and lipes by rules not traceable to first principles, but dependent upon a set of special and exceptional conditions; and in the imaginative sphere the accepted symbols did not express the deepest and most permanent emotions, but were an arbitrary compromise between traditional assumptions and the new philosophical tenets. (4) In the age of Dryden and Pope, the subjects of poetry were found in city life and in social man. Politics, party-spirit and argument, wit and satire, criticism and scientific inquiry took the place of nature.

1. In his Tractate on Education Milton says, "In those vernal seasons of the year when the air is calm and ple asant, it were an injury and sullenness against nature, not to go out and see her riches, and partake in her rejoicing intth heaven and earth". p. 59.

2. P. I. IX, $445 f f$.

3. Cf., Shairp: Op. Cit., 192.

4. Lesile Stephen: 으. it. II, 448. 

James Thomson, Thomas Gray, and William Collins were among the first poets to return to nature. But they returned through books. Not until Cowper, Burns, and Wo rdsworth did English poets study and love nature for herself. Thomson's theory of frost in Winter and of springs returning to their sources in Autumn are distinctly Lucretian. Had he been a clo se student of nature he would scarcely have made that remarkable mistake in The Seasons. Just after sunset,

- - - -rising slow,

Blank in the leaden-coloured east, the moon

Wears a wan circle round her blunted horns.

Only a full moon can rise as the sun sets, and the phenomenon to which Thomson's refers is seen only with a new moon, which, of course, is in the west at sunset. (1)

As Milton's minor poems have been so influential elsewhere, it is fair to as sume that their poetical treatment of nature may have been bor rowed from. When Thomson was writing The Seasons he was a close student of Milton. While he wrote with his eye upon nature, and expressed facts and images never conceived before, while his adjectives and descriptive words are often very appropriate, many of his descriptions are mere enlargements of Milton's one-line pictures. His twenty-five lines in Spring on a spring shower are concisely put in Milton's Iine (130) from II Penseroso. He follows Milton in describing the world not with the accuracy of a photograph but

1. W. H. Browne in Color Chords in Thomson's Seasons, Modern Ianguage Notes, XI, I4I, has pointed out this error. 

in bold outlines. He does not describe a forest, but the forest. He records only general impressions. Milton's use of nature in his figures is often such as to indicate that the artificial object was more beautiful or more familiar than the natural object. For instance,

- - - - - Sea-girt isle

That like to rich and various gems inlay

The unadorned bosom of the deep.

Thomson uses nature in his similes in much the same way, especially in the castle of Indolence. Thomson always blends man with his landscape; he does not describe a snowstorm for it self, but for the hardships it works on fowls, beasts and men. Milton never describes a landscape for its own sake. Thomson does not describe the ocean and rarely mentions mountains. Milton refers to them only by name. Thomson's sense of color was keen; Milton had a special fondness for light and color. Thomson's ear was remarkably sensitive; Milton has six hundred eleven allusions to sound. (1) Thomson returned to nature, but he returned by way of books, and largely by way of Milton. This would seem to be a natural result of the fact that.Milton, the first poet of pure natural description, was his early poet guide, and that he was the last man in English poetry who had described nature.

Collins' descriptions of nature have a sweet pathetic tone. He was the first poet since Milton wrote his early

1. Squires: Op. Cit., 466 . 

lyrics who brought to the description of rural things that perfection of style that combined simplicity and beauty. He shows some unusual originality and imaginative power. Gray maintained this movement. His fine feeling for nature is more apparent in his letters than in his poetry. Yet he has some fine touches in his poetry. He is at his best in the Elegy, and there has drawn from the English landscape alone all that is necessary for the quiet and pathos of his situation. Ordinarily, mythology and classicism come in between him and nature; "the rosy-bosomed hours, fair Venus' train" usher in spring, the nightingale is "the Attic warbler", the insects have to preach a sermon to justify the notice that is taken of them. Gray was perhaps capable of feeling the "impulse from the vernal wood" as truly as Wordsworth, but he would have altogether rejected the doctrine that it could teach him more than all the sages. (I) In short, Gray and Collins, like Milton, were lovers of books before they were lovers of the country. Their style was formed by a more or less intimate study of poetry. A reference to the parallel passages bearing.upon nature, quoted elsewhere in another connection, will show how many times the imaginative descriptions of nature that Thomson, Gray, and Collins employ, come from Milton. Iike Milton, they were thoughtful, cultivated men, with convictions and sentiments of their own - sentiments main-

1. Iiving Age: Gray and his School, 272. 

ly of the II Penseroso type. They saw nature through the light of these sentiments, and sought out those scenes and images in nature which suited their habitual mood. They regarded nature in a meditative, moralizing way. For them, as for Milton, there was no rapture in the presence of nature. They treated her, as did Milton, through books.

. In general it may be said that Milton seldom reacted to nature simply and directly; he rarely gives utterance to a lyrical cry; he was never aroused to song by impressions from nature. The reaction was checked and did not find expression until he had considered his own feelings and modified or altered them upon the suggestion of his intellect. Nature harmonizes and sympathizes with man and his moods. He not infrequently employs what Ruskin terms the "Pathetic Fallacy". The same statement holds true, in the main, for Thomson, Gray, and Collins. Nature to them was the nature of melancholy, (I) nature harmonizing with their moods, nature altered and modified by their intellect. Thomson has more real feeling for nature than the other two poets who have been considered, but even his nature-love, as manifested in his poetry, was probably first stirred into life by the natural descriptions found in poetry and especially in llitton's lyrics. He did not return to nature so much as he pointed the way for those who came after him back to nature from artificiality.

1. Thomson opens his Winter

See, Winter comes to rule the varied year Sullen and sad,

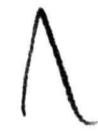



VIII. Minor Characteristics.

Thomson, Gray, and Collins have other characteristics in common with Milton which serve to enforce the evidence which has been offered in confirmation of the statement that Milton Influenced Thomson, Gray, and Collins in language, thought, and form. Milton was almost wholly lacking in a sense of humor; aside from one or two of his juvenile poems, there is scarcely a trace of it. Collins seems to have had no sense of humor; Thomson's attempts, like Milton's, are heavy and farfetched; Gray's friends speak of his possessing a very keen sense of humor, but it is $r$ arely apparent in his poems. Milton has introduced no children; none are found in Collins; Thomson and Gray make one reference each to children in an incidental way. ( Aut. 134lff., and Elegy, 23ff.) Milton was a student. Deep study removes men from life, absorbs them in themselves, purifies their conduct, with some risk of isolating their sympathies. Consequently, Milton was deficient in a knowledge of plain human nature; he has no profound touches of humanity, no sudden felicities of insight into character. There is no evidence of the interpretation or understanding of humanity in Collins or Gray; Thomson possessed this gift only to a very limited degree. Milton's poems, his themes, are all abstract; they represent his thoughts and feelings about abstract thoughts and generic types. His characters in Paradise Iost are types. 

Eve is a kind of abstract woman, the Miltonic conception of the "eternal feminine" (Das ewige Weibliche) in nature. Thomson, Gray, and Collins with but few exceptions have chosen abstract conceptions as themes for their poems. Milton was notoriously fond of high romance and Gothic diableries; Collins was wholly carried away by the same attachments. (2) Like Milton, Collins has the rich economy of expression haloed with thought, which by single or few words often hints entire pictures to the imagination. Milton was a genuine lover of and fighter for liberty. "The general idea around which he grouped the cycle of his prose writings is liberty; in his earliest series of pamphlets he pleaded for ecclesiastical liberty; in others, he presented his ideal of domestic liberty; and in yet others he vindicated the civil liberties of his country." (3) Thomson was the first poet to take up the fight after Milton's death. But his long poem Liberty is more a talk about liberty than it is a plea in its behalf. Swinburne is responsible for the statement that Collins was the first poet after Milton to blow again the clarion of republican $f$ ath and freedom; to reannounce with the pasion of a lyric and heroic $r$ apture the divine right and the Godlike duty of tyrannicide. (4) Milton stamped his own personality

1. Dowden: Transcipts and Studies, 456.

2. Cf., British poets, II, 128.

3. Dowden: Puritan and Anglican, 174.

4. Ward; The English Poets, III, 281. 

upon his poems. Although his subject in some degree forbade reference to his personal history, he has impressed the stamp of his own individuality, his own character, moral as well as intellectual, as deep on all he has written as if his theme had been ever so directly himself. A reader of the Iliad and Odyssey forgets that Homer must have been a sentient being. "Who in the delineation of the wrath of Achilles finds a trace of the temper or the character of the delineator? Who in Milton's Satan does not recognize much of Milton himself? (1) As Lowell says, "Other poets are possessed by their theme, he is self-possessed, his great theme being John Milton, and his great duty that of interpreter between htm and the world." (2) Iike Milton, the characters of Gray and Collins, and to some extent, that of Thomson, are indelibly left upon their joems. The subjects of the Romanticists of course make their subjective expressions more pardonable. They at tempted to suppress themselves and to interpret the emotion that a.l men feel at times. But they express not so much the melancholy reflections common to mankind as those possessed by themselves. A reader of Collins and Gray sees the personal life and character of Collins and Gray in every line.

It is after all not a surprising fact that Thomson, Gray, and Collins should have been attracted to Milton and his poems.

1. Craik: A Compendious History of English Iiterature and of 2. Among the English Language, IT, 

Gray's temperament in particular was not unlike Milton's. In many ways his life was a melancholy one. His vitality was low, and such happiness as he enjoyed was of the languid kind. Physically and emotionally he was unfit to cope with realities. As he himself said, he was spoiled by retirement. He was horrified at $f$ inding himself a celebrity; he declined to be Poet Laureate; he refused honorary degrees; when at Cambridge the young scholars are said to have left their dinners to see him as he passed in the street, it was a sincere pain to him. It is not to be wondered that his diffident and fastidious inclinations, his high and seclusive dignity, his contemplative soul should have been attracted by Milton and his ideal II Penseroso.

Then, too, both Milton and Gray were Puritans; both were imbued with Hebraistic conceptions. Both were musicians with keenly sensitive feelings for all the delicate posstbilities of music. Both were great students of the classics. Gray was the greatest scholar among the English poets with the posible exception of Milton. Perhaps it would be more accurate to say that Milton's scholarship was the greatest and Gray's the best. (2) Gray's longest poem is in Latin, De Principiis Cogitandis, and he must have taken a great pleasure in reading Milton's Lat in elegies. Both were Cambridge graduates, and their

1. Bronson: Thomas Gray, 120.

2. Phelps: selections from the prose and Poetry of Thomas Gray, XV, 

Iife there cannot have been very unlike. We know that Gray's was solitary and seclusive with very few friends. Milton seems to have held himself aloof from his fellow-clas smates, and probably had very few, if any, congenial friends. He himself says that he left college "accompanied by the regrets of most of the fellows", who showed him "no common marks of friendship and esteem". (I) But he felt himself to be out of sympathy with his surroundings and whenever in after years he spoke of Cambridge it was with the feeling that the years spent there had been the most unprofitable of his life. (2) Gray's later days, when he was ill, dejected, with his body so pitifully unequal to projecting his soul on its way, are not incomparable to the pathetic darkness of Milton's old age.

Collins, too, had a temperament not unlike Milton's. He was passionately fond of music. (3) He is said to have had very few associates, and the last six years of his life, spent in a low-spirited and melancholy condition, at times wholly deprived of his faculties, and terminating in insanity and an early death, explain much of his love for "Melancholy Iiterature" and for Milton.

Thomson resembles Milton less in temperament than either Gray or Collins. Iike the two latter, however, he was never married, and his later years seem to have been tinged with

1. The Second Defense, 108 .

2. Verity: Op. Cit.; XI.

3. W. Moy Thomas: Memoir of Collins, XXXIII. 

mel ancholy regrets and forebodings.

Thomson, Gray, and Collins knew, loved, and believed in the same great masters that Milton cherished. Spenser was the poet of poets to them all. All sat at the feet of the philosopher Plato, the Grecian Homer, and the Latin Virgil. Their poetic and philosophic loves were in common with those of Milton's. Thomson makes Milton Homer's equal when he says,

Behold who yonder comes in sober state, Fajr, mild, and strong, as is a vernal sun 'Tis Phoebus' self, or else the Mantuan swain! Great Homer too appears, of daring wing, Parent of song! and equal by his side The British muse; joined hand in hand they walk Darkling full up the middle steep to $f$ ame.

Win. 530-536.

It should not be concluded that Thomson, Gray, and Collins worked together or were influenced by each other. Collins (1721-1759) and Gray (1716-1771) were contemporaries and they borrowed from a common master. Yet in spite of the fact that their names are almost inseparable now, each lived and did his work independent of the other. The career of collins practically closed before the end of the half-century and before 

Gray came prominently before the public. (1) There is no evidence that Gray and Thomson ever met, but in 1744, Collins formed a friendship with Thomson which lasted until 1748, the year of Thomson's death. This event gave us that exquisite elegy of Collins' beginning, "In yonder grave a Druid lies." But Thomson's poetical ideas seem not to have influenced Collins or Gray. Each poet went separately and voluntarily to Milton.

1. Gosse: History of Eighteenth Century Iiterature, 231. Cf., also Gosse: Modern EngIish Liter ature, 233, and Beers: Op. Cit., 155 . 



\section{CONCLUSIONS}

In this study the conclusions based upon the evidence offered are -

I. That Milton influenced Thomson, Gray, and Collins in their use of language to a very great extent and in a very fundamental manner.

Two hundred twenty-four passages have been cited in which Thomson, Gray, and Collins have borrowed lines or parts of lines from Milton. Milton's poems were almost unknown from the time of $h$ is death until the Romantic revival in the eighteenth century. His diction was not passed on from mouth to mouth nor from poet to poet. The common sources are so few as to be practically neglected. Thomson, Gray, and collins in all probability borrowed the se two hundred twentyfour passages directly from Milton. Their debt to him is largely in the matter of adjectives and nouns. This indicates an influence of the deepest and most fundamental kind. II. That Milton influenced Thomson, Gray, and Collins in their conceptions of the mental, moral, physical, and spiritual worlds.

One hundred twenty-four passages that suggest, rather than exhaust the conceptions of Milton which have been paralleled by Thomson, Gray, and Collins have been cited to substantiate the statement. The entire body of Thomson's, Gray's, 

Collins' works is characterised by a spirit of melancholy which is suffused and interwoven into their poems. This conception seems to have been inspired largely by II Penseroso. Twenty-one passages have been quoted to intimate the extent of the influence of this poem upon Thomson, Gray, and Collins. III. That Milton influenced Thomson, Gray, and Collins in form.

Thomson's blank verse is Miltonic in its use of pauses, verse-paragraphs, and alliteration; he attempted Milton's "grand style". Milton's influence upon Thomson's juvenile poems is evidenced by the fact that three of his early poems, Psalm CIV, Paraphrased, A Pastoral upon the Birth of our. Saviour, On May, are subjects upon which Milton also wrote; that two of his early poems, To Seraphina, and A Nuptial Song have the swing of Milton's octosyllabic iambics, and that four of his early poems, Lisy's Parting with her Cat, To the Memory of Sir Isaac Newton, Brittania, and To the Memory of Mr. Congreve are attempts at Milton's blank verse. There is external and internal proof of Milton's influence upon Gray in form. He is sald to have been unable to read blank verse other than Milt on's, and in four places in the small volume of his poetical works, he has praised and eulogized Militon's form. Three of his poems, Epitaph on Mrs. Clarke, The Descent of Odin, and The Triumphs of Owen bear clear influences of Milton's lyric style. One stanza of his Ode for Music is written in the 

metre of Milton's Nativity Ode. Collins has rendered homage to Milton's form, once in his Ode on the Poetical Character, and twice in On Our Late Taste in Music. His Ode to Evening is written in the metre which Milton used in his translation of an ode of Horace's, and in his Ode to Simplicity, Collins employs the metre of Milton's Nativity Ode. The evidence offered in proof of Milton's influence upon the form of Thomson, Gray, and Collins is enforced by the fact that thirteen of Milton's characteristics and subleties of style are employed by these Romanticists.

After all, the influence of one personality upon another is a very subtle and elusive thing. Many general characteristics of Milton's style and personality may have attracted and influenced the Romanticists. Some specific instances of his influence upon Thomson, Gray, and Collins in the matter of language, conception, and style have been siezed upon, and the forms and extent of this influence indicated. On the whole, the inherent characteristics and natural endowments of Thomson, Gray, and Collins were such that it is very fitting and natural that for their poet-guide and master they should have chosen him who, as he himself said, was

Cut off. from the cheerful ways of men 



\section{A $\underline{B} \underline{\mathrm{B}} \underline{\mathrm{E}} \underline{\mathrm{V}} \underline{\mathrm{A}} \underline{\mathrm{T}} \underline{\mathrm{I}} \underline{\mathrm{O}} \underline{\mathrm{N}} \underline{\mathrm{S}}$.}

John Milton

Arc.

Com.

Circum.

Death of Inf.

II P.

I'A.

March. Win.

May Morn.

Nat. Ode.

Passion.

P. I.

P. $\mathrm{R}$.

Ps.

S. Agon.

Shak.

Sol. Music.

Time.

Univ. Carrier.

Vac. Exer.
Arcades.

Comus.

Upon the Circumcision.

On the Death of a Fair Infant Dying of a Cough.

Il Penseroso.

I'Allegro.

An Epitaph on the Marchioness of Winchester.

Song on May Morning.

On the Morning of Christ's Nativity.

The Pasion.

Paradise Lost.

Paradise Regained.

Psalm.

Samson Agonistes.

On Shake spe are.

At a Solemn Music.

On Time.

On the University Carrier.

At a Vacation Exercise. 



\section{James Thomson}

Aeol. Harp.

Aut. .

Beauty •

Brit.

Cast. Ind.

Count. Iife.

Happiness.

Hymn.

I.Newton.

Iib.

Iịsy's Cat.

Morn. Count.

Mr. congreve.

Past. Th. Cory.

Past. Dav. Th.

Prince Wales.

Ps. CIV.

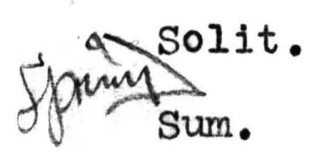

Win.
An Ode on Aeolus's Harp.

Autumn.

On Beauty.

Brittania.

The Castle of Indolence.

Of a Country Life.

Upon Happiness.

A Hymn.

To the Memory of Sir Isaac Newton.

Iiberty.

Iisy's Parting with her Cat.

The Morning in the Country.

4. Poem to the Memory of Mr. Congreve.

A Pastoral Betwixt Thirsis and Corydon, upon the Death of Damon.

A Pastoral Betwixt David, Thirsts, and the Angel Gabriel, upon the Birth of Our Saviour.

To His Royal Highness, the Prince of Wales.

Psalm CIV. Par aphrased.

Hymn on Solitude.

summer?

Winter. 

Thomas Gray

$\begin{array}{ll}\text { Advers. } & \text { Hymn to Adversity. } \\ \text { Agrip. } & \text { Agrippina. } \\ \text { Bard. } & \text { The Bard. } \\ \text { Cons. Odin. } & \text { The Descent of odin. } \\ \text { Eton Col. } & \begin{array}{l}\text { Ode on a Di stant Prospect of Eton } \\ \text { College. }\end{array} \\ \text { Educ. and Gov. } & \text { The Alliance of Education and Govern- } \\ \text { ment. } & \text { Elegy Written in a Country Churchyard. } \\ \text { Elegy. } & \text { The Fat al Sisters. } \\ \text { Ignor. } & \text { Hymn to Ignorance. } \\ \text { Long Story. } & \text { A Long Story } \\ \text { Music. } & \text { Ode for Music. } \\ \text { Prog. Poes. } & \text { The Progress of Poesy. } \\ \text { Rich. West. } & \text { Sonnet on the Death of Richard West. } \\ \text { Sp. Ode. } & \text { Ode on the Spring. } \\ \text { Trans. Stat. } & \text { Translation of a Pas sage from Statius. } \\ \text { Viciss. } & \text { Ode on the Pleasure arising from } \\ & \text { Vicissitude. }\end{array}$





\section{William Collins}

Death Thom.

Even.

Fear.

Iib. Ode.

Mann.

Mercy.

Ode of 1746 .

Or. Ec.

Pas sions.

Poet. Char.

Pe àce.

PIty.

Pop. Super.

Simplic.

Thos. Han.

Ver ses.
Ode on the Death of Mr. Thomson.

Ode to Evening.

Ode to Fear.

ode to Liberty.

The Manners.

Ode to Mercy.

Ode Written in the Beginning of the year 1746.

Oriental Eclogues.

The Passions.

Ode on the Poetical Character.

Ode to Peace.

Ode to Pity.

An Ode on the Popular Superstitions of the Highlands of Scotland.

Ode to Simplicity.

An Epistle addressed to Sir Thomas Hanmer.

Verses Written on a Paper. 



\section{$\underline{B} \underline{I} \underline{B} \underline{I} \underline{I} \underline{O} \underline{G} \underline{R} \underline{A} \underline{\underline{H}} \underline{\underline{Y}}$}

Bascom, John: Philosophy of English Literature.

G. P. Putnam's Sons, New York, 1892.

Beers, Henry A.

A History of English Romanticism in the Eighteenth Century.

Henry Holt \& Company, New York, 1906.

Benson, Arthur C. Essays.

Macmillan \& Company, New York, 1896.

Bridges, Robert Milton's Prosody.

Oxford, 1901.

Bronson, Walter $\mathrm{C}$. English Poems.

University of Chicago Press, Chicago, 1908.

Bronson, Walter C. The Poems of William Collins.

Ginn \& Company, Boston, 1898.

Browne, R. C. English Poems by John Milton.

Clarendon Press series, Oxford, 1906.

Chambers, David I. The Metre of Macbeth. Princeton University Press, I903.

Corson, Hiram. A Primer of English Verse. Ginn \& Company, Bostōn, 1902.

Courthope, W. J. A History of English Poetry. Macmill an \& Company, New York, I903.

Courthope, W. J. The Liberal Movement in English

John Murray, London, 1885. IIterature.

Craik, George L.

A Compendious History of English

- Literature and of the English

Ianguage from the Forman Conquest.

Charles Scribner's Sons, New York, I890.

Crawshaw, William H. The Making of English Literature.

D. C. Heath \& Company, Boston, 1907.

Dowden, Edward.

Purit an and Anglican: Studies in

Henry Holt \& Company, New York, 1901. 

Elton, Oliver. The Augustan Ages.

Charles Scribner's Sons, New York, 1899.

Fletcher, Priscilla.

A Study of English Blank Verse 1558-1632.

Colorado College PubIications, December 1907.

Garnett, Richard. Prose of Milton.

Walter Scott, London, 1894 .

Garnett, R. and Go sse, K. English Literature: An Illustrated

London, 1903.

Gosse, Edmund. English Odes.

Kegan, Paul, French \& Company, London, 1899.

Gosse, Edmund. A History of Eighteenth Century

The Macmillan Company, New York, I889.

Gosse, Edmund. Modern English Literature.

Frederick A. Stokes Company, New York, 1897.

Gosse, Edmund. Thomas Gray, Fnglish Men of Letter

Harper \& Brothers, New York. Series.

Littell's Living Age. Gray and His School.

Vol., 142: 259-272.

Gummere, Francis B. A Handbook of Poetics.

Ginn \& Company, Bostōn, 1895.

Gurteen, S. Humphreys. The Epic of the Fall of Man. G. P. Pu'tnam's Sons, New York, 1896 .

Harrison, J. S.

Platonism in English Poetry of the

New York, 1903.

Sixteenth and Seventeenth Centuries.

Johnson, Samuel.

The Seasons with the Iife of the

Jacob Johnson \& Company, Philadelphia, 1795.

Lewis, Charlton M.

Lockwood, Laura F. Lexicon to the English Poetical

The Macmillan Company, New York, 1907 . 



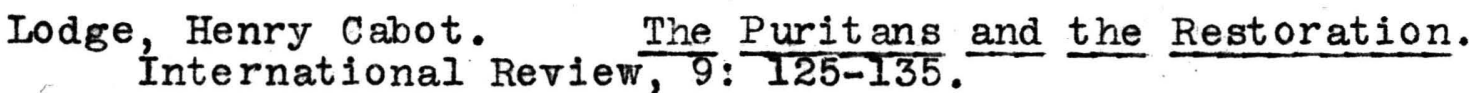

Lowe Il, James Russell. Among My Books: Second Series. Hought on, Mifflin \& Company, I899.

Mas son, David.

The Iife of John Milton narrated in connexion with the Political, Ecclesiastical, and Iiterary History of his

Macmillan \& Company, Iondon, 1881.

Mas son, David. The Poetical Works of John Milton. The Macmillan Company, London, 1890.

Mayor, Joseph $B$.
University Press, Cambridge,
1901 . Chapters Metre.

Mitford, $J$.

Poetical Works of Thomas Gray.

Houghton, Mifflin \& Company, Boston.

Morel, Leon.

James Thomson: Sa vie et ses oeuvres. Iibraire Hachette et Companie, Paris, 1895 .

Nicolas, Sir Harris.

The Poetical Works of James Thomson. Houghton, Miffin \& Company, Boston, 1863 .

Nicolas, Sir Harris. The Poetical Works of William Collins. Houghton, Mifflin \& Company, Boston.

Omond, T. S.

Oxford University Press, 1907.

Pattison, Mark.

Harper \& Brothers, 1894.

Perry, T. S. At lantic Monthly,

English Metrists in the Eighteenth and Nneteent centuries.

Milton: English Men of Letter Series.

Gray, Collins, and Beattie. $46: 810-81 \%$.

Phelps, William lloyd. The Beginnings of the English Romantic Ginn \& Company, Boston, 1893.

Phelps, William Iyon. Selections from the Poetry and Prose Ginn \& Company, Boston, 1902.

Raleigh, Walter. Milton.

G. P. Putnam's Sons, New York, 1900. 

Robertson, J. Logie. Thomson's Seasons and Castle of Clarendon Press Series, Oxford, I891.

Saint sbury, George. A Hi st ory of Elizabethan Ii terature. The Macmillan Comp any, New York, $\overline{1887 .}$

Saintsbury, George. A History of English Prosody. The Macmillan Company, New York, 1906.

Scherer, Edmund. Essays on English Iiterature. Charles Scribner's Sons, New York, I891.

She dd, W. G. T. Literary Essays. Charles Scribner's sons, New York, 1878.

Smith, Goldwin. The United Kingdom. The Copp, Clark Company, Toronto, 1899.

Squires, Vernon P. Milton's Treatment of Nature. Modern Ianguage Note s, 9:454.

Stephen, Leslie. History of English Thought in the Smith, Flder \& Company, Iond on $\frac{\text { Century }}{1881 .}$

Stern, Alfred.
Englische studien IV, $\frac{\text { Milton }}{326 .}$ und seine Zeit.

Symonds, J. A.
Fortnightly Review, The $\frac{\text { Blank }}{767}$ Verse of Milton. Thomas, W. Moy.
George Bell \& Sons, The Poetical Works of William Collins.

Verity, A. W. The Cambridge Milton for Schools. University Press, Cambri dge, 1907.

Von Klenze, Camillo. Iiterature on the Nature Sense. Journal of Germanic Philology, 2 : $239-265$. Ward, Thomas Humphrey The Macinillan Company, New York, $\frac{\text { English }}{1895}$.

Warton, Thomas. History of English Poetry. Reeves \& Turner, London, 187\%.

Wendell, Barrett. The Temper of the Seventeenth Century Charles Scribnerds Sons, New York, 1904. 

Dictated to C. G. B. 






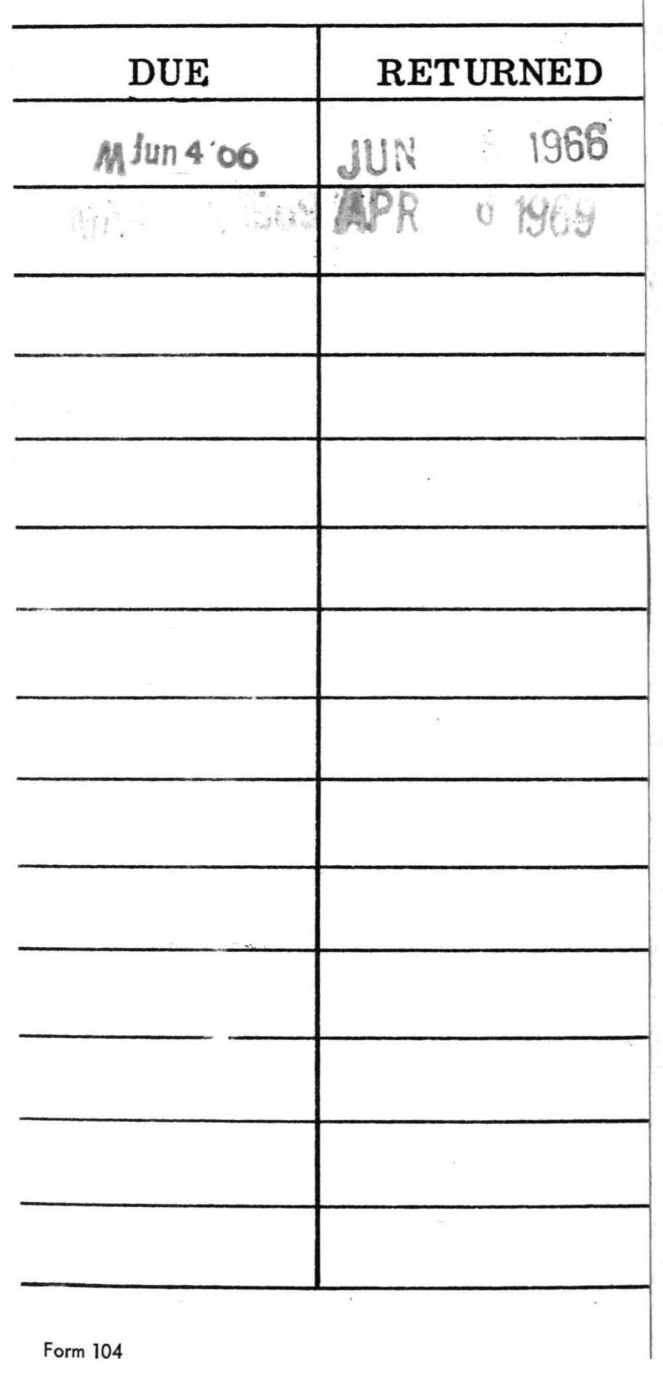


